\title{
Qualitative and Quantitative Analysis of Carbonate Waters in the Peters Mountain Region of Monroe County, WV
}

\author{
Emily A. Bausher \\ eabausher@mix.wvu.edu
}

Follow this and additional works at: https://researchrepository.wvu.edu/etd

Part of the Geology Commons, and the Hydrology Commons

\section{Recommended Citation}

Bausher, Emily A., "Qualitative and Quantitative Analysis of Carbonate Waters in the Peters Mountain Region of Monroe County, WV" (2018). Graduate Theses, Dissertations, and Problem Reports. 3741. https://researchrepository.wvu.edu/etd/3741

This Thesis is protected by copyright and/or related rights. It has been brought to you by the The Research Repository @ WVU with permission from the rights-holder(s). You are free to use this Thesis in any way that is permitted by the copyright and related rights legislation that applies to your use. For other uses you must obtain permission from the rights-holder(s) directly, unless additional rights are indicated by a Creative Commons license in the record and/ or on the work itself. This Thesis has been accepted for inclusion in WVU Graduate Theses, Dissertations, and Problem Reports collection by an authorized administrator of The Research Repository @ WVU. For more information, please contact researchrepository@mail.wvu.edu. 
Qualitative and Quantitative Analysis of Carbonate Waters in the Peters Mountain Region of Monroe County, WV

\author{
Emily A. Bausher
}

Thesis submitted to the Eberly College of Arts and Sciences at West Virginia University in partial fulfillment of the requirements for the degree of Master of Science in the Department of Geology and Geography

\author{
Dorothy J. Vesper, Ph.D., Chair \\ Joseph Donovan, Ph.D. \\ Nicolas P. Zegre, Ph.D. \\ Department of Geology and Geography
}

Morgantown, West Virginia

2018

Keywords: springs, geochemistry, thermal patterns, vulnerability Copyright 2018 Emily Bausher 


\section{ABSTRACT \\ Qualitative and Quantitative Analysis of Carbonate Waters in the Peters Mountain Region \\ of Monroe County, WV}

Emily A. Bausher

Water in Monroe County, WV is used extensively for public and private supply and requires quantification, chemical analysis, and assessment for contamination susceptibility. Over 250 springs were previously identified in the eastern side of Monroe County on or near Peters Mountain; 14 were continuously monitored in this study. Springs were grouped based on geologic and spatial distribution: interbedded clastic-rock springs on the mountain flanks, carbonate springs in the valley, and a thermal spring associated with the St. Clair thrust fault. Clastic and carbonate springs have calcium-magnesium-bicarbonate chemistries, neutral pHs and high alkalinities; the thermal spring has calcium-magnesium-sulfate-carbonate chemistry, low $\mathrm{pH}$, high specific conductance and high alkalinity; stream discharge locations have a

combination of clastic and carbonate signatures. Clastic springs have high $\mathrm{Ca}^{2+} / \mathrm{Mg}^{2+}$ ratios and carbonate springs exhibit two molar ratio signatures: dolomite ratios $\sim 1$ and limestone ratios $>1$.

Composite discharge from the study area ranges from $1-15 \mathrm{~m}^{3} / \mathrm{s}$; one creek accounts for $\sim 40 \%$ of the total flow. No significant correlations were observed between discharge and the following parameters: major ions, E. coli and total coliform bacteria, non-purgeable organic carbon. Temperature responses were analyzed using cosine curve fit analysis. Quantitative measures included amplitude dampening factors and lag times. Low amplitude dampening factor and short lag time springs have greater surface connection and vulnerability.

An overall spring analysis was completed using a composite ranking assessment based on surface connection and temperature signal propagation parameters. This characterization identified CRABT, HATCH, and OLSON as the most vulnerable springs in this study. 


\section{ACKNOWLEDGEMENTS}

This project was completed with partial support provided by the following: WVU Community Engagement Grant, Experiment.com Crowd-Sourcing, WVU Appalachian Freshwater Initiative (NSF-EPSCOR 1458952) and the WV Department of Health and Human Resources (Agreement Number G180409).

I would like to thank my advisor Dr. Dorothy Vesper for her support and guidance during this project and for introducing me to the breathtaking corner of West Virginia where this project takes place. I've had the most amazing experience and thanks to your teachings, I have learned so much along the way. Also, Dr. Joe Donovan for his help in data interpretation and stress relief (squash games).

I would also like to thank the members of the Indian Creek Watershed Association (IWCA) who strive to protect the water in Monroe County through citizen education and involvement. Their help in coordinating with land owners, access to spring and discharge locations, their hospitality, and their assistance collecting samples made this project possible. Specifically, I would like to acknowledge Howdy and Suzie Henritz, Nancy Bouldin, Fred and Barbara Ziegler, and Dana Olson. Monroe County is lucky to be home to such passionate and ambitious protectors of water.

Additionally, I would like to thank my many field assistants and fellow lab-mates for assistance with data collection and interpretation: Travis Wilson, Autum Downey, Kyle Lee, Jonney Mitchell, and Jill Riddell.

A special thanks to my family and friends for their unwavering support through this process. 


\section{TABLE OF CONTENTS}

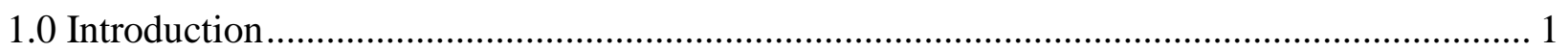

2.0 Purpose and Objectives ............................................................................................... 2

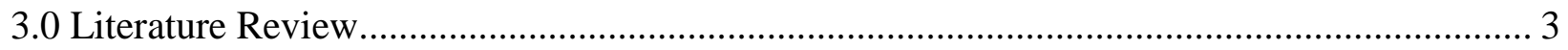

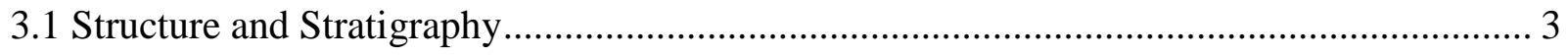

3.2 Hydrogeochemical ..................................................................................................... 3

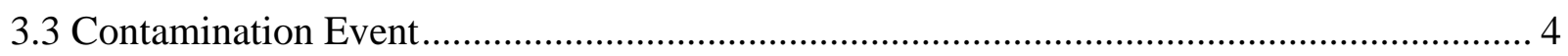

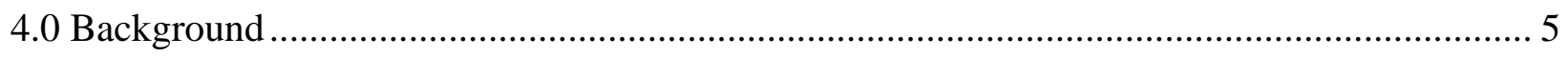

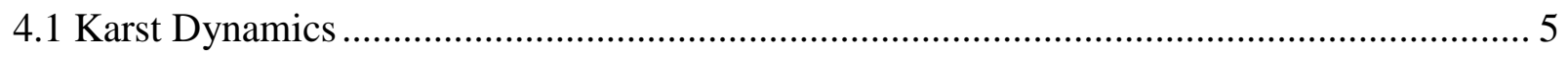

5.0 Study Area

5.1 General Setting, Physiography and Land Cover ………..................................................... 7

5.2 Geologic Setting ....................................................................................................... 7

5.3 Watershed Information...................................................................................................... 11

5.4 Site Location Descriptions ............................................................................................. 11

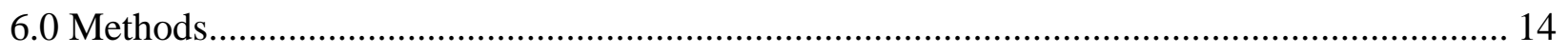

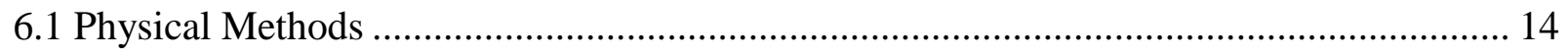

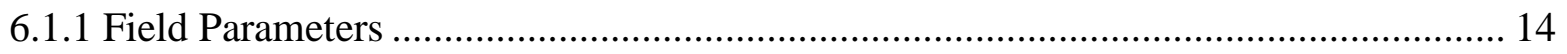

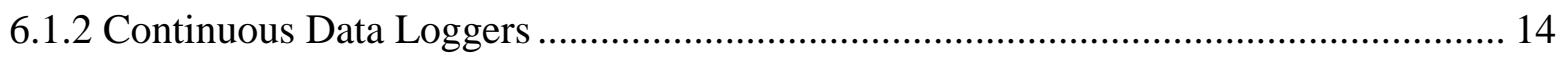

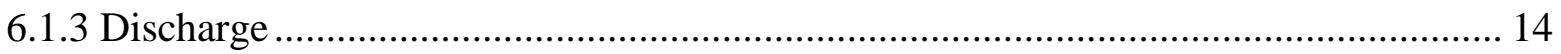

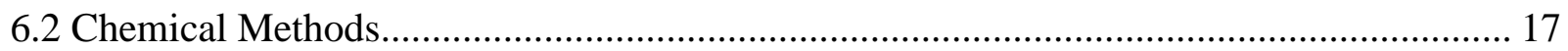

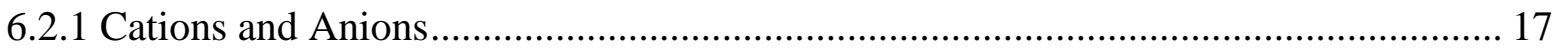

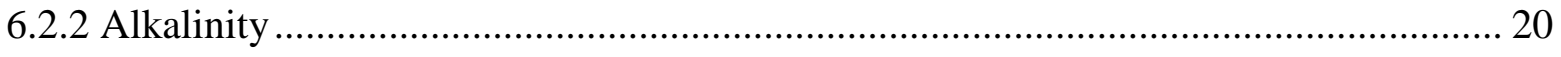

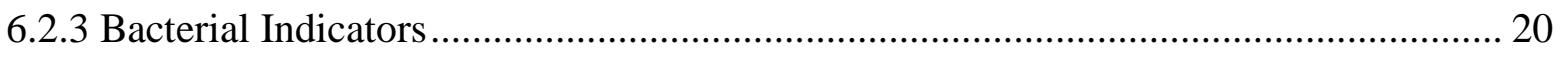

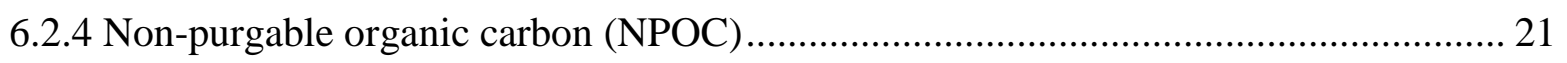

6.2.5 Ionic Strength, $\mathrm{P}_{\mathrm{CO} 2}$, and Mineral Saturation Indices .................................................... 21 


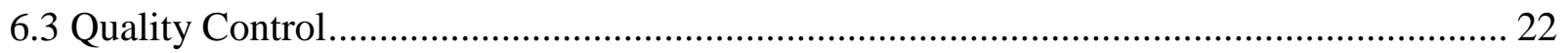

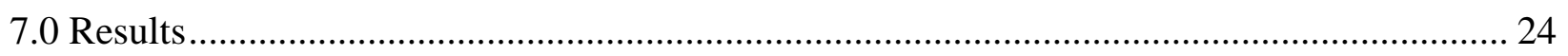

7.1 Spatial Distribution and Characterization of Springs........................................................... 24

7.2 Field Measurements ................................................................................................. 24





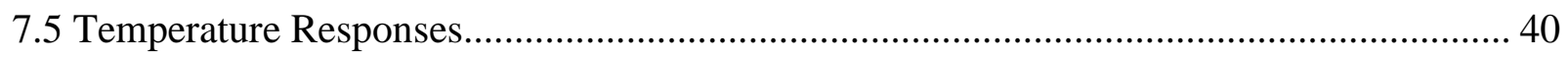



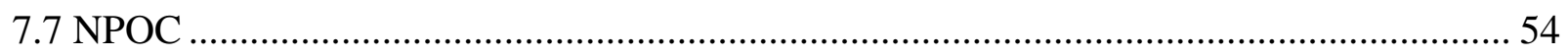

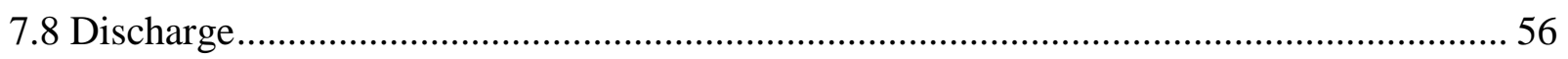

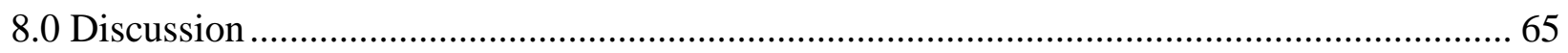

8.1 Physical and Chemical Reconnaissance................................................................................. 65

8.2 Thermal Variability ........................................................................................................... 67

8.3 Overall Connection of Springs to Land Surface ……………………………………....... 71

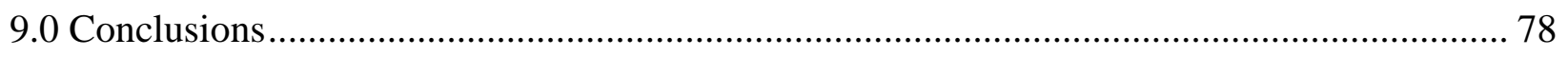

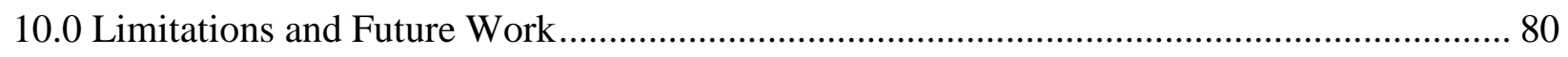

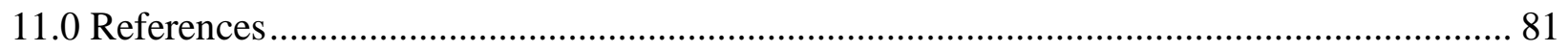

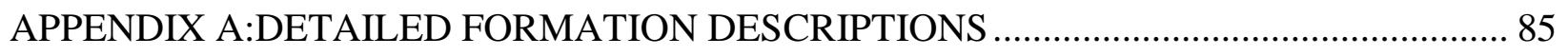

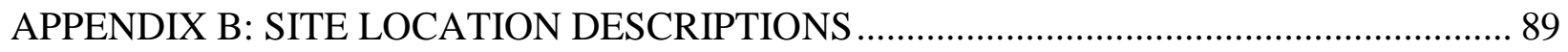

APPENDIX C: TABULATED DISCHARGE DATA ……………………………….................... 102

APPENDIX D: TABULATED CHEMICAL AND METER DATA............................................ 108 


\section{LIST OF FIGURES}

Figure 1: a) Map of the location of Monroe County within West Virginia b) Appalachian Plateau and Valley and Ridge physiographic provinces within Monroe County. Peters Mountain marks the transition between the two provinces. c) Hillshade of Monroe County. Light colors indicate higher elevations and major towns are labeled. d) Land cover data from the National Land Cover Dataset. Major towns are labeled. e) HUC 8 and HUC 10 watersheds in Monroe County. The colors represent HUC 8 watersheds and the red lines represent HUC 10 watersheds. Tributary rivers and discharge locations are also indicated.

Figure 2: Generalized Stratigraphic Section of the Monroe County, WV area. Modified from McDowell and Shultz (1990), WVGES Stratigraphic Chart (2014) and USGS Online Mineral Resources

Figure 3: a) Geologic map of Monroe County including the St. Clair thrust fault. The study area is marked by the outlined box. b) Map of generalized lithology with all springs and discharge locations. Springs within the study area not included in this study are also plotted.

Figure 4: a) Schematic to calculate the staff gage datum ( $\left.\mathrm{y}_{\mathrm{G}}\right)$ at all installation locations. b) Schematic to calculate adjusted stages to stream morphology. Adjusted stages $\left(\mathrm{H}_{\text {stream }}\right)$ are calculated by adding the stage at the staff gage $\left(\mathrm{H}_{\text {staff }}\right)$ to adjustments for the stream profile depth $\left(\mathrm{OFF}_{\text {staff }}\right)$. Continuous pressure transducer data were also



Figure 5: ICP-OES filtered vs. digested cation analysis results from March, 2016. A 1:1 parity line is displayed in black. 19

Figure 6: Spatial distribution of springs by elevation along Peters Mountain, WV. Data are compiled from this study, Richards (2006), and Springs of West Virginia (1986).... 25

Figure 7: Cave and spring distribution by formation along Peters Mountain, WV. Tuscarora and Clinton Formations are grouped together in this study. Data are sourced from this study, Richards (2006), Springs of West Virginia (1986), and Caves and Karst of Monroe County, WV (1975).

Figure 8: Schematic figure illustrating the general relationships between elevation, formation and spring group in this study. The springs are broken into three groups based on 
formation: carbonate, thermal, and clastic. GMILL and ECH plot on top of each other but are two separate clastic springs. APPL spring is not included in this study but is added here to mark the formation associated with the top of Peters Mountain. The vertical thin dotted lines mark the Devonian, Ordovician and Silurian age formations. The thick dotted line marks an approximate elevation profile estimated from Google Earth. This profile was taken from NE to SW just south of the town of Lindside. The surface exposure of the St. Clair thrust fault is marked with a dark arrow. Note, spring deviations from this approximate profile are due to elevation heterogeneity along the extent of the mountain

Figure 9: Temperature, pH, and SC for all locations from September 2015 to December 2017. Springs are plotted by formation and discharge locations are plotted by name. The number of locations are indicated below the corresponding names. Standard deviations are marked with error bars. Data symbols are spring groups and discharge locations. 29

Figure 10: pH, Temp, and SC at all locations. Error bars are standard deviations. Data symbols are spring groups and discharge locations.

Figure 11: Major cation and anion piper plot for all locations. Samples were gathered from September 2015 to December 2017. Data symbols are spring groups and discharge locations. Samples with charge balances greater than $\pm 10 \%$.

Figure 12: a) $\mathrm{Ca} / \mathrm{Mg}$ molar ratios compared to calcium concentrations for all locations. b) Average $\mathrm{Ca} / \mathrm{Mg}$ molar ratios for all spring locations separated by formation. Data symbols are spring groups and discharge locations.

Figure 13: Average spring alkalinities grouped by formation and spring grouping. Error bars are standard deviations and data symbols correspond to spring groups.

Figure 14: Plot of $\mathrm{SI}_{\text {calcite }}$ Vs. the partial pressure of $\mathrm{CO}_{2}\left(\mathrm{P}_{\mathrm{CO} 2}\right)$ in collected samples calculated using PHREEQC modeling software. Data symbols correspond to spring groups and discharge locations. Calcite equilibrium is marked by the solid horizontal line and $\mathrm{P}_{\mathrm{CO} 2}$ in equilibrium with the atmosphere is marked with the solid vertical line. The dashed lines represent calcite precipitation and dissolution barriers. Solid diagonal lines (a), (b) and (c) represent theoretical degassing at $\mathrm{Ca}^{2+}$ activities of $6 \times 10^{-3}, 3 \times 10^{-3}$ 
and $1 \times 10^{-3}$, respectively (White, 1997). OLSON shows an anomalously low $\mathrm{SI}_{\text {calcite }}$ value on $4 / 29 / 2017$.....

Figure 15: NADP WV04 raw temperature data (gray) and temperature cosine curve fit (black).

Figure 16: Continuous raw temperature data at all springs are plotted in gray and temperature cosine curve fits are in black. Cosine curve fits were evaluated on a 365 day cycle. Relative sum of squares and $\mathrm{R}^{2}$ values are displayed to evaluate model fit. Data excludes MEFF (data logger lost and when a new logger was reinstalled there were not enough data to evaluate a cosine fit). Plots are organized by amplitude dampening factors: a) springs with amplitude dampening factors less than 15, b) springs with amplitude dampening factors from 16-25, and c) springs with amplitude dampening factors greater than 25. OLDSWT data may not be representative of spring water and may be associated with the spring pool and surface water input. See

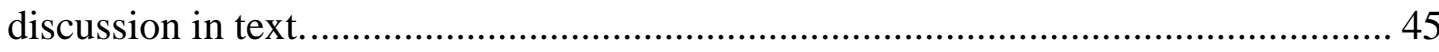

Figure 17: Temperature cosine fit models for all springs separated by amplitude dampening factors. The NADP WV04 cosine fit curve is plotted here at the top of the figure. Note the difference in temperature scale in the springs with higher amplitude dampening factors $(16-25$ and $>25)$.

Figure 18: Amplitude dampening factors for all springs grouped by formation. Data symbols correspond to spring groups. OLDSWT data may not be representative of spring water and may be associated with the spring pool and surface water input. See discussion in text.

Figure 19: Amplitude dampening factor-lag time relationships for all springs. Data symbols correspond to spring groups; labels are individual spring locations. OLDSWT data may not be representative of spring water and may be associated with the spring pool and surface water input. See discussion in text......

Figure 20: E. coli and total coliform bacterial results for all locations compared to weekly rainfall data. The upper panel displays total coliform counts for a) springs and b) discharge locations. The lower panel displays E. coli counts for a) springs and b) discharge locations. Data symbols correspond to spring groups and discharge 
locations. OLDSWT data may not be representative of spring water and may be associated with the spring pool and surface water input. See discussion in text....... 53

Figure 21: Measured combined total discharge is plotted on the top y-axis. The bottom y-axis shows percentage of contributions to the total discharge from all five locations. Creek labels correspond to the adjacent colors and percentages. Data were collected from October 2016 to August 2017.

Figure 22: Continuous stage-discharge rating curves for all five discharge locations. a) Stagedischarge relationships include stream profile corrections. Relationships are represented by linear and power functions. Note, QHAN only contains four data points after the installation of the well point. b) Stage-discharge relationships without a stream profile correction, represented by a power function....................................... 58

Figure 23: Graphs a)-d) show final adjusted stage at QSWT, QRCH, QSEC, and QHAN through time. Stage is plotted in black on the left y-axis and rainfall is plotted in gray on the right y-axis. The barometric control data logger is located at QIND, a discharge location not shown here because adjusted stage could not be calculated. a) QSWT is the furthest discharge location from the barometric pressure logger and b) QHAN is located the closest. Arrows indicate the installation of well points to contain the pressure loggers. The blue shaded region indicates when well points were displaced from the streams due to high flow.

Figure 24: Stage is plotted in black on the left $y$-axis and rainfall is plotted in gray on the right y-axis. a) Stage at USGS Indian Creek gage 03177480 in Red Sulphur Springs, WV through time. b) Stage at QIND in this study through time. Locations are approximately 13 kilometers away. The arrow indicates the installation of well points to contain the pressure loggers. 61

Figure 25: Total coliform and E. coli counts in indicator springs compared to measured total discharge. Data from OLSON and ZEN are plotted on the left (a) and data from GMILL and CRABT are plotted on the right (b). The thermal spring is not included due to pavement and spring pool influence. Analyte concentrations are graphed on yaxes and total discharge is graphed on $\mathrm{x}$-axes. Indicator springs are plotted according to spring grouping. 63 
Figure 26: NPOC concentrations in indicator springs compared to measured total discharge. Data from OLSON and ZEN are plotted on the left (a) and data from GMILL and CRABT are plotted on the right (b). Analyte concentrations are graphed on y-axes and total discharge is graphed on x-axes. An outlier at ZEN spring $(50.55 \mathrm{mg} / \mathrm{L}, 2.07$ $\mathrm{m} 3 / \mathrm{s}$ ) was excluded. The thermal spring is not included due to pavement influence. Data symbols correspond to spring groups and discharge locations.

Figure 27: Regional comparison of calcite and dolomite saturation indices for OLSON, HATCH, and CRABT springs. 66

Figure 28: Temperature response schematic adapted from Luhmann et al. 2011 within the context of the triple porosity model (White, 2002).

Figure 29: Amplitude dampening factors in clastic springs at various elevations within the Reedsville Formation. The blue oval represents Reedsville Formation springs in the middle extent of Peters Mountain located within 6 kilometers of each other. The red oval represents Reedsville Formation springs in the southern extent of Peters Mountain located within 12 kilometers of each other. OLDU spring is located in the northern most extent of Peters Mountain in Monroe County, 14 kilometers away from the northern most spring in the middle extent of the mountain. 70

Figure 30: Characterization of surface connection in all spring locations. Locations are grouped by spring group, age and a relative cross sectional profile from $\mathrm{W}$ to $\mathrm{E}$. Amplitude dampening factor and lag time are plotted on the left and $\mathrm{Ca}^{2+}$ (Max/Min), NPOC, Total coliform, and E. coli are plotted on the right. On the left, springs with high surface connection have low values; on the right, springs with high surface connection have high values. The surface connection parameters (Ca Max/Min, NPOC, Total coliform, and E. coli) are normalized to the minimum value among all springs. OLDSWT data are questionable due to surface input and the spring pool.






\section{LIST OF TABLES}

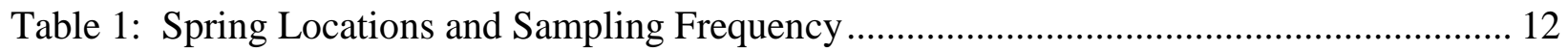

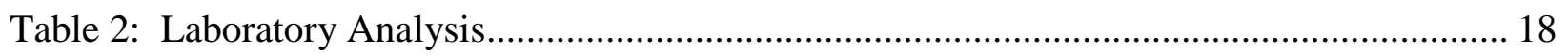

Table 3: Quality Control Analysis for Field Blank.............................................................. 23

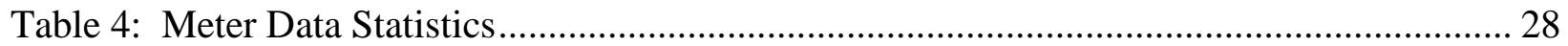

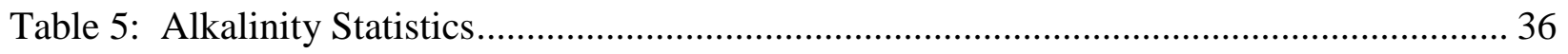

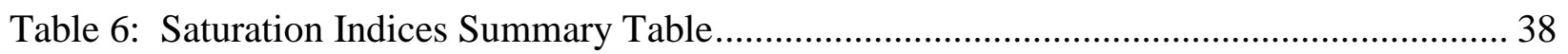

Table 7: Correlation Matrix for Carbonate and Clastic Springs ............................................ 41

Table 8: Correlation Matrix for the Thermal Spring ............................................................ 42

Table 9: Spring Temperature Responses Based on Cosine Fit Models ................................... 46

Table 10: Total Coliform and E. coli Results ................................................................... 52



Table 12: Individual Spring Surface Connection Index Evaluation ....................................... 73

Table 13: Composite Surface Connection Ranking............................................................. 76

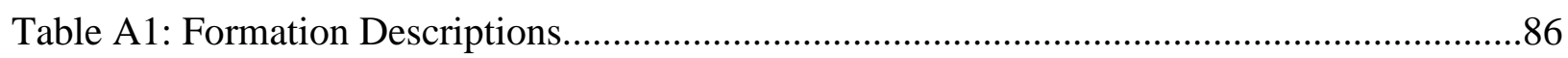



Table C1: QRCH Adjusted Stage and Discharge.............................................................103

Table C2: QSWT Adjusted Stage and Discharge.............................................................104

Table C3: QSEC Adjusted Stage and Discharge................................................................105

Table C4: QHAN Adjusted Stage and Discharge................................................................106

Table C5: QIND Adjusted Stage and Discharge..............................................................107

Table D1: Tabulated Cation and Anion Data....................................................................109

Table D2: Tabulated Meter, Alkalinity, and E.coli and Total Coliform Data...........................116 


\section{LIST OF APPENDICES}

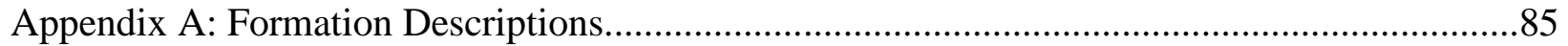



Appendix C: Tabulated Discharge Data..............................................................................102

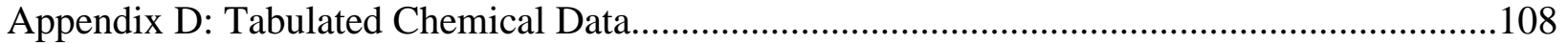




\section{LIST OF ABBBREVIATIONS AND ACRONYMS}

ADV - Acoustic Doppler Velocimeter

DIC— Dissolved Inorganic Carbon

E. coli-Escherichia coli

HUC - Hydrologic Unit Code

IC- Ion Chromatography

ICP-OES - Inductively Coupled Plasma Optical Emission Spectroscopy

ICWA - Indian Creek Watershed Association

MPN_ Most Probable Number

NADP — National Atmospheric Depositional Program

NDIR — Near Dispersive Infrared

NPOC— Non-Purgable Organic Carbon

NRCCE - National Research Center for Coal and Energy

PWS — Public Water Supply

RSPSD— Red Sulphur Public Service District

RSS-Relative Sum of Squares

SC_- Specific Conductance

$\mathrm{SI}_{\mathrm{x}}$ - Saturation Index for Mineral " $\mathrm{x}$ ”

USGS — United States Geologic Survey

WVGES - West Virginia Geologic and Economic Survey 


\subsection{Introduction}

The border of southeastern West Virginia and southwestern Virginia is composed of a combination of carbonate and mixed-sedimentary (clastic) rocks with a complex structural history. The Alleghenian Orogeny occurred approximately 300 million years ago as the Iapetus Ocean closed and Laurentia collided with Gondwanaland to form the super-continent Pangea. Crustal shortening was accommodated by the folding and thrusting of sedimentary layers perpendicular to the principle stress of the collision, resulting in the Valley and Ridge Province. The folded and fractured rock within the Valley and Ridge makes the interpretation of groundwater systems challenging.

An additional complication to the groundwater systems in the region involve the presence of karst terrain. Karst features provide an interaction between surface and subsurface water involving the dissolution of rock. A rapid surface-aquifer transmission is seen in karstified landscapes through the formation of caves, conduits and sinkholes (White, 2002). Due to the nature of karst features, it is problematic to determine the extent of water available in carbonate aquifers as well as the interactions between sources and spring waters. The combination of complex structural history and karst terrain makes contamination identification and tracking difficult.

Monroe County is located in southeastern West Virginia. Historically, the economy of Monroe County revolved around its use of surface water and groundwater. Farming, logging, watermills, and mineral water resorts provided the county with economic value. Today, this area of West Virginia still relies heavily on these economic bases. Water wells within the region are used for both public and private supply as well as for commercial water bottling. The importance of groundwater resources in this region of West Virginia is immense; thus, the protection of these waters is imperative. This study will aid in the quantification and chemical analysis of the water available in the region surrounding Peters Mountain and the susceptibility of this water to contamination. 


\subsection{Purpose and Objectives}

The water in the Peters Mountain area provides home owners with a source of residential water, but also feeds three public water supplies and the Sweet Springs bottling company. In total, the water is used by over 60\% of Monroe County residents (pers. comm., Indian Creek Watershed Association, Board of Directors, 2/7/2016). Valuable research has been done in the past, but there is likely a mixture of deep and shallow aquifers feeding the springs due to the complex nature of the geologic structure and the presence of karst terrain. No previous studies have analyzed the short and long-term responses/behaviors in this spring-dominated area. The purpose of this study is to determine and evaluate the most vulnerable resources in the region.

The overarching goal of this study is to characterize and quantify water associated with Peters Mountain using long-term chemical and physical evaluations.

The objectives of this project are:

1. Create a master database of the Peters Mountain area in the form of Microsoft Access and ArcGIS that include existing spring data and acquired data from this project. These data will include both chemical and physical reconnaissance (latitude/longitude, discharge, temperature, $\mathrm{pH}$, alkalinity, specific conductance (SC), major cations and anions, nonpurgable organic carbon (NPOC), and indicator organism counts including total coliform and E. coli bacteria.

2. Assess the vulnerability of the springs through time based on:
a. Chemical and physical variations ( $\mathrm{pH}$ and SC)
b. Thermal responses
c. Indicator organisms and total organic carbon

3. Quantitatively evaluate the amount of water associated with the springs on Peters Mountain using discharge data and rating curves

4. Identify areas of complexity for future geologic mapping based on the above results 


\subsection{Literature Review}

\subsection{Structure and Stratigraphy}

Structural and stratigraphic reports of the southern Appalachian Mountains are available, but have not been reevaluated in high resolution since the late 1990’s. A comprehensive structural analysis of the Alleghenian Orogeny in southeastern WV was performed by Dean et al. (1988). Folded Cambrian to late Mississippian rocks, trending $\mathrm{N}^{\circ} \mathrm{E}-\mathrm{N} 35^{\circ} \mathrm{E}$, are evident in central Appalachia and fault-dominant structures, trending $\mathrm{N} 60^{\circ} \mathrm{E}$, are seen in southern Appalachia (Dean et al., 1988).

The St. Clair thrust fault defines the Allegheny Structural Front through Monroe County and marks the boundary between central and southern Appalachia (Dean et al., 1988). The Narrows, Pulaski and Saltville thrust faults are found to the southeast (Dean et al., 1988). A $30^{\circ}$ bend in the Structural Front towards the northwest is evident in the middle of Monroe County (McDowell and Schultz, 1990). The St. Clair fault extends from northeastern to southeastern Monroe County, with more complicated splays in the north. The formation of this fault involved fault-bend folding as well associated trishear deformation (Sturms, 2008).

A stratigraphic analysis and generalized stratigraphic section were completed by McDowell and Schultz (1990), and again by Dean and Kulander (1992) using classifications specific to Monroe County. This region is underlain by a Cambrian to Mississippian carbonate platform with a total estimated thickness of 4,572 meters (McDowell and Schultz, 1990).

\subsection{Hydrogeochemical}

Richards (2006) conducted hydrological and geochemical characterization of springs from the non-carbonate rock units (referred to as “clastic units”) on the ridge, eastern and western slope of Peters Mountain and carbonate springs on the western slope of Peters Mountain. These sites lie on the border of Indian Creek and Sweet Springs watersheds. He identified 244 springs and sampled 150 for $\mathrm{pH}$, SC and flow and 30 for major-ion chemical analysis. Springs flowing from clastic rocks yielded groundwater chemistries similar to regional rainfall. Carbonate springs showed variations in $\mathrm{Ca} / \mathrm{Mg}$ ratios were attributed to differing lithology. Before Richards' research, few hydrologic studies of fresh water were completed in the area.

$\mathrm{CO}_{2}$ mineral springs and travertine precipitation rates in thermal waters were studied by Moore (2002) in northeastern Monroe County. This study involved rates and inhibiting factors 
of precipitation as well as sources of error in travertine rate measurements in Sweet Springs Creek using ceramic precipitation plates. It was observed that areas with high biological activity showed more variability between calculated and observed precipitation rates (Moore, 2012). This research identified the importance of deep flow-paths and the presence of warm water in the region.

\subsection{Contamination Event}

The Red Sulphur Public Service District (RSPSD) in Peterstown, WV oversees the distribution of more than 300,000 gallons of drinking water to Monroe County citizens daily (RSPD, 2014). Coburn and Hancock springs are the main supplies of water for the RSPSD. Secondary reserve water sources include Rich Creek and the Fish Hatchery spring. In July 2015, petroleum contamination was detected in Coburn Spring. Distribution was shut down for 20 days, costing the county $\$ 12,000$ in replacement water fees (Adams, 2015). Twenty-six 55gallon drums of material were removed from the contamination site 610 meters away from the spring (Adams, 2015). This contamination event displays the need for subsurface interpretation of karst areas in Monroe County, to identify high risk springs if another event were to occur. 


\subsection{Background}

\subsection{Karst Dynamics}

Karst terrain is shaped by the interaction between water and soluble carbonate rocks such as limestone and dolomite. Surface water and groundwater in karst environments are in close communication (White, 2002). The dissolution of carbonate rocks, due to the interaction with surface water, creates features in the subsurface that influence groundwater flow. Groundwater flow in karst aquifers can exhibit three types of permeability: matrix, fracture, and conduit (White, 2002). Sinkholes and conduits promote fast flow while in the absence, flow is controlled primarily by fractures. Aquifers near Peters Mountain are likely controlled by a combination of conduit and fracture permeability due to structural deformation.

Karst geochemistry is generally controlled by the interaction between the inorganic carbon system $\left(\mathrm{CO}_{2}-\mathrm{H}_{2} \mathrm{O}\right)$ and limestone or dolomite. The $\mathrm{CO}_{2}-\mathrm{H}_{2} \mathrm{O}$ system is described by the following three dissociation equations at $25^{\circ} \mathrm{C}$ :

$$
\begin{aligned}
& \mathrm{CO}_{2}(g)+\mathrm{H}_{2} \mathrm{O} \leftrightarrow \mathrm{H}_{2} \mathrm{CO}_{3}{ }^{*} \quad p K_{\mathrm{CO} 2}=1.47 \\
& \mathrm{H}_{2} \mathrm{CO}_{3}{ }^{*} \leftrightarrow \mathrm{HCO}_{3}{ }^{-}+\mathrm{H}^{+} \quad p K_{a 1}=6.35 \\
& \mathrm{HCO}_{3}{ }^{-} \leftrightarrow \mathrm{CO}_{3}{ }^{2-}+\mathrm{H}^{+} \quad p K_{a 2}=10.33
\end{aligned}
$$

The $\mathrm{CO}_{2}-\mathrm{H}_{2} \mathrm{O}$ system is the main control on $\mathrm{pH}$ in natural waters. The main dissolved inorganic carbon in solution are dissolved $\mathrm{CO}_{2}$ and carbonic acid (in combination, $\mathrm{H}_{2} \mathrm{CO}_{3} *$ ), bicarbonate $\left(\mathrm{HCO}_{3}{ }^{-}\right)$, and carbonate $\left(\mathrm{CO}_{3}{ }^{2-}\right)$. The above equations are controlled by either atmospheric or soil zone $\mathrm{P}_{\mathrm{CO} 2}$ in combination with $\mathrm{pH}$. Various species dominate the $\mathrm{CO}_{2}-\mathrm{H}_{2} \mathrm{O}$ system at different pHs: dissolved $\mathrm{CO}_{2}\left(\mathrm{H}_{2} \mathrm{CO}_{3}{ }^{*}\right)$ at low $\mathrm{pH}$, bicarbonate at neutral $\mathrm{pH}$, and carbonate at high $\mathrm{pH}$.

Carbonic acid is the primary acid involved in the dissolution of carbonate rocks during the formation of karst terrain (White, 1988). The dissolution of limestone is driven by acidic conditions, evident in the following reaction:

$$
\mathrm{CaCO}_{3}(\mathrm{~s})+\mathrm{H}^{+} \leftrightarrow \mathrm{Ca}^{2+}+\mathrm{CO}_{3}^{2-} \text { at } 25^{\circ} \mathrm{C} \mathrm{K}_{s p}=10^{-8.48}
$$

Under more acidic conditions, the reaction proceeds to the right, dissolving limestone. This equation produces carbonate ions, linking the $\mathrm{CO}_{2}-\mathrm{H}_{2} \mathrm{O}$ system with the dissolution of limestone. The net reaction of the dissolution of limestone by carbonic acid is:

$$
\mathrm{CaCO}_{3}(\mathrm{~s})+\mathrm{H}_{2} \mathrm{O}+\mathrm{CO}_{2}(\mathrm{~g}) \leftrightarrow \mathrm{Ca}^{2+}+2 \mathrm{HCO}_{3}{ }^{-}
$$


The activity of $\mathrm{H}_{2} \mathrm{CO}_{3}{ }^{*}$ increases linearly with increasing $\mathrm{P}_{\mathrm{CO} 2}$. Thus, greater amounts of limestone can be dissolved at higher PCO2 levels and at lower temperatures. The effect of temperature on the dissolution of limestone is much less compared to the effect of $\mathrm{P}_{\mathrm{CO} 2}$ (White, 1988).

Karst geochemistry is closely linked to hydrology. Saturation indices describe the likelihood a mineral will dissolve or precipitate and is based on the comparison of the product of the ion activity in solution to a mineral's equilibrium solubility coefficient. The following general formula defined by Langmuir is used to derive saturation indices for mineral " $\mathrm{x}$ ” $\left(\mathrm{SI}_{\mathrm{x}}\right)$ (Langmuir, 1971):

$$
S I_{x}=\log _{10} \frac{I A P}{K_{s p}}
$$

Where the IAP is the ion activity product and the $\mathrm{K}_{\mathrm{sp}}$ is the solubility product for mineral $\mathrm{x}$.

Positive saturation indices indicate a solution that is supersaturated and will precipitate mineral " $\mathrm{x}$ ". Saturation indices of zero indicate equilibrium conditions. Under-saturated waters produce negative saturation indices and will dissolve mineral " $\mathrm{x}$ ” until saturation (equilibrium) is met. The interaction of these "aggressive" (undersaturated) waters with soluble rock results in the creation of caves and sinkholes.

The ratio of dissolved $\mathrm{Ca}^{2+}$ to $\mathrm{Mg}^{2+}$ depends on the formation in which the water is found (Langmuir, 1971). Ratios greater than 1 are indicative of limestone formations and ratios of equal proportions are indicative of dolomite formations. This ratio can be utilized to identify and distinguish what White identifies as "groundwater basins", analogous to drainage basins on the surface (White, 2002). 


\subsection{Study Area}

\subsection{General Setting, Physiography and Land Cover}

Monroe County is located in the southeastern portion of West Virginia. Major towns in Monroe County include: Peterstown, Union, Gap Mills, and Sweet Springs (approximately from South to North). The topography varies greatly within the county; relief within the study area is $\sim 550 \mathrm{~m}$, increasing towards the East (Figure 1).

Monroe County is separated into two physiographic zones associated with the Alleghenian Orogeny: the Appalachian Plateau in the West and the Valley and Ridge Province in the East (Figure 1). Monroe County's economy primarily relies on farming and logging and is covered by deciduous forest (68\%) and pastures/hay (20\%) (Figure 1) (Homer et al., 2015).

\subsection{Geologic Setting}

A stratigraphic column for the area was adapted from descriptions by McDowell and Shultz (1990), Dean and Kulander (1992), the West Virginia Geological and Economic Survey generalized WV stratigraphy (WVGES Chart, 2014), and the United States Geologic Survey (USGS) online mineral resources webpage (Geologic Units in Monroe County, WV) (Figure 2). Detailed lithologic descriptions can be found in Appendix A.

The geology in Monroe County consists of younger, more flat-lying rocks in the northwest and older, highly folded and faulted rocks in the southeast. Rocks in Monroe County's Appalachian Plateau are mostly Mississippian in age with some Devonian outcrops closer to the St. Clair thrust fault (Figure 3). The St. Clair thrust fault is difficult to constrain in Monroe County due to lack of surface exposure, but marks the Appalachian Structural Front (Dean et al., 1988). Fault splays have been mapped in the north near Sweet Springs Valley (Moore, 2012).

The flat-lying rocks are dominated by the Mauch Chunk Series and the Greenbrier Formation. The Mauch Chunk Series includes limestone and calcareous shale interbeds that grade upward into shale. The Greenbrier Formation is a karst-forming limestone with many sinkholes and caves. The rocks in the Valley and Ridge Province (east of the St. Clair thrust fault) are the focus of this study and can be generalized into three geologic groups: carbonate valleys, interbedded clastic sedimentary units along the mountain flanks, and sandstone ridge formers. The carbonate valleys consist of the Ordovician Beekmantown Formation, the New 



Legend

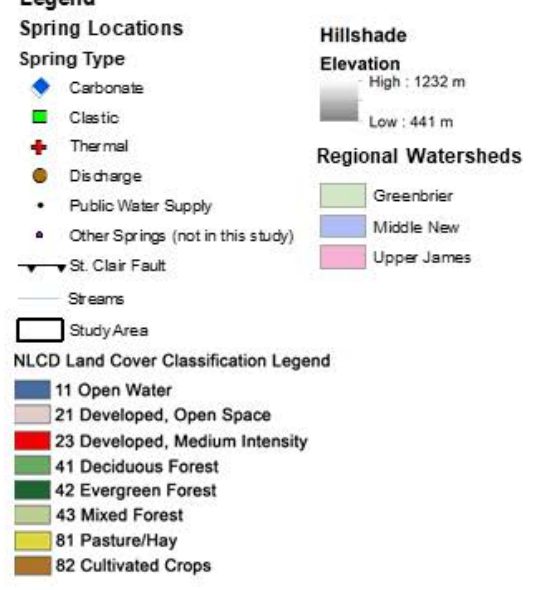

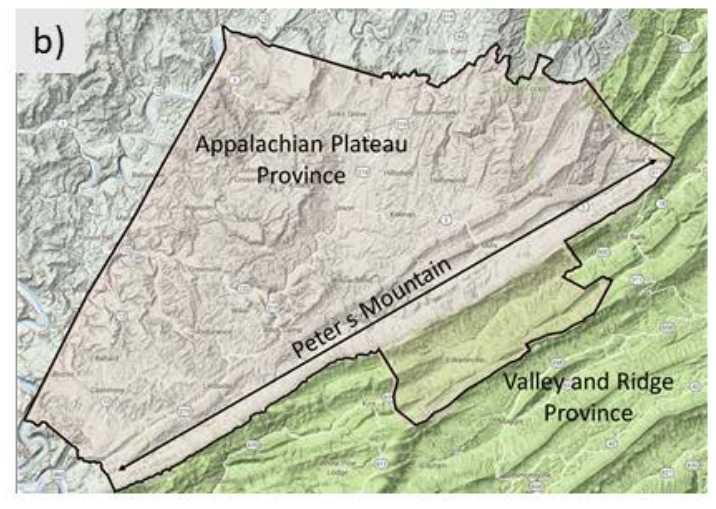

d)



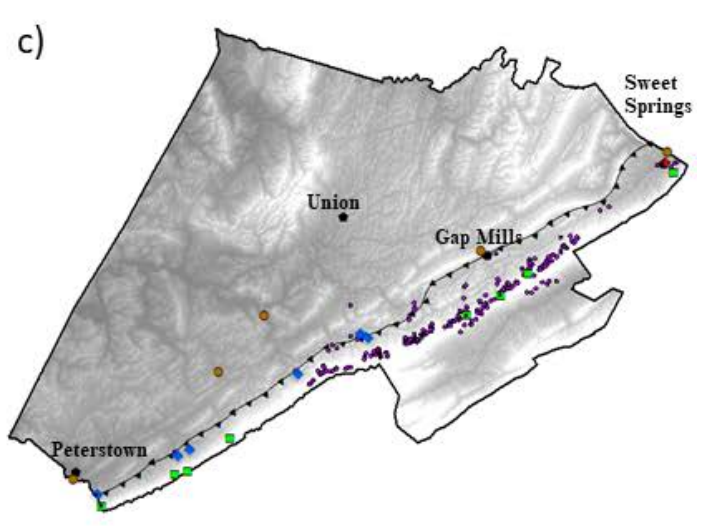

e)

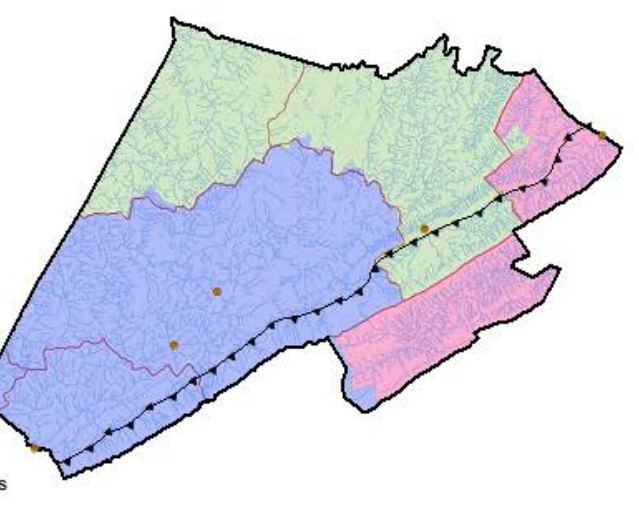

Figure 1: a) Map of the location of Monroe County within West Virginia b) Appalachian Plateau and Valley and Ridge physiographic provinces within Monroe County. Peters Mountain marks the transition between the two provinces. c) Hillshade of Monroe County. Light colors indicate higher elevations and major towns are labeled. d) Land cover data from the National Land Cover Dataset. Major towns are labeled. e) HUC 8 and HUC 10 watersheds in Monroe County. The colors represent HUC 8 watersheds and the red lines represent HUC 10 watersheds. Tributary rivers and discharge locations are also indicated. 


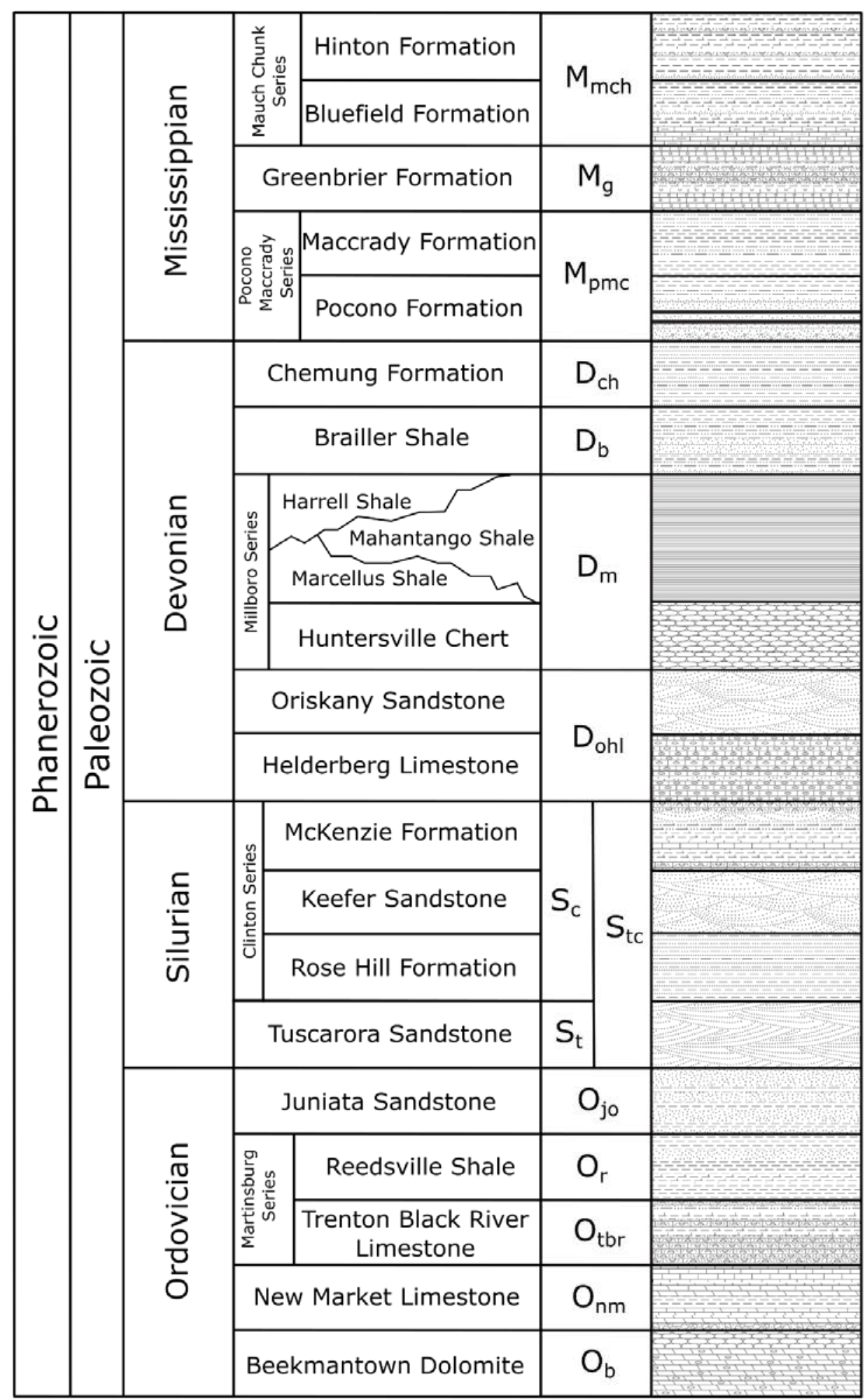

Figure 2: Generalized Stratigraphic Section of the Monroe County, WV area. Modified from McDowell and Shultz (1990), WVGES Stratigraphic Chart (2014) and USGS Online Mineral Resources 

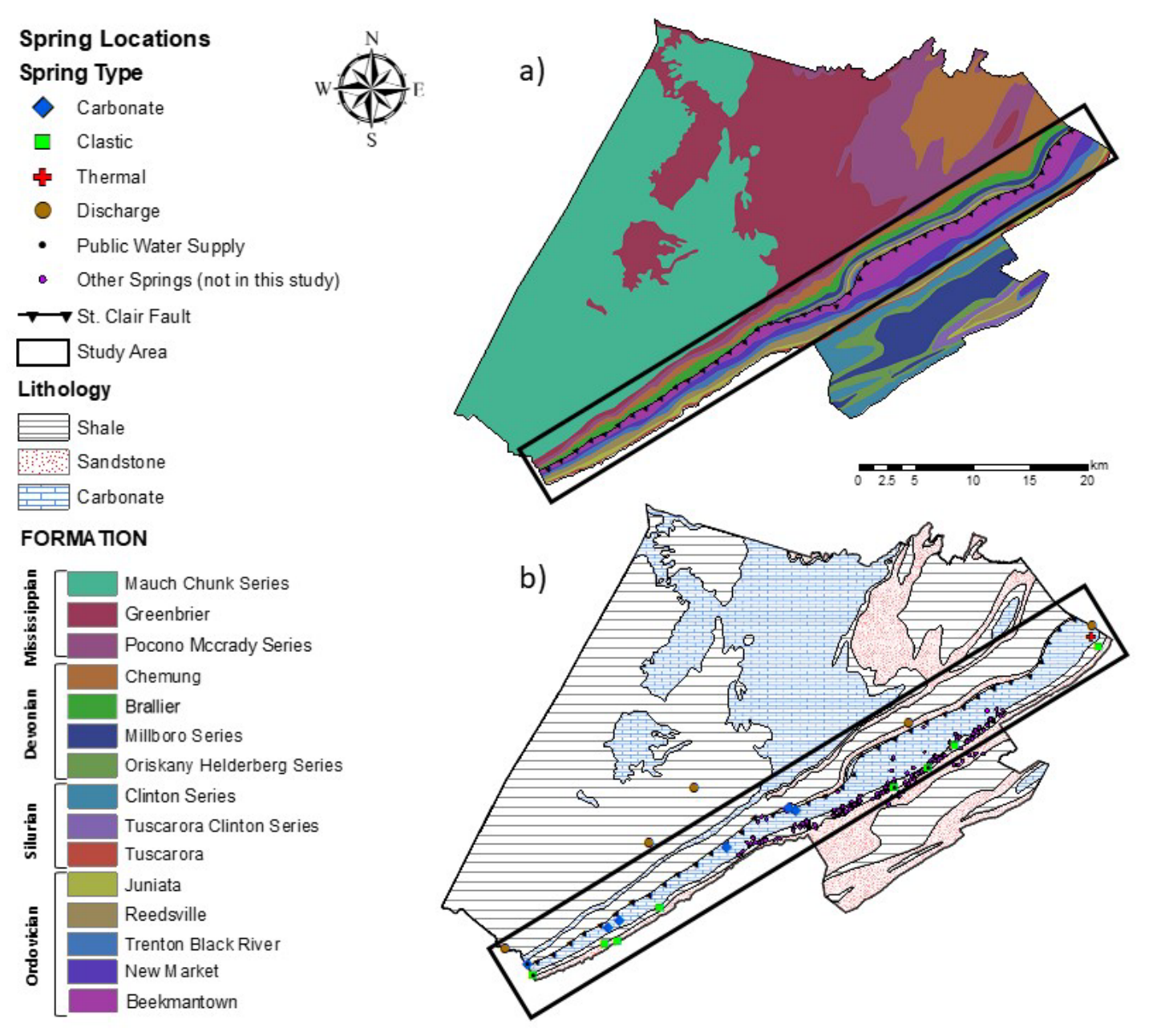

Figure 3: a) Geologic map of Monroe County including the St. Clair thrust fault. The study area is marked by the outlined box. b) Map of generalized lithology with all springs and discharge locations. Springs within the study area not included in this study are also plotted. 
Market Formation and the Trenton/Black River Formation. The Beekmantown and New Market formations have chert nodules and interbeds. The Trenton/Black River Formation consists of the Trenton limestone and the Black River Formation; they are grouped together in this project due to similarity. The Trenton/Black River Formation grades upward into the Reedsville Formation. The Ordovician interbedded clastics on Peters Mountain flanks consist of the Reedsville and Juniata formations. The Reedsville Formation is a shale with calcareous siltstone and sandstone interbeds while the Juniata Formation is a gray to red sandstone with interbedded shales. The main ridge formers of Peters Mountain are the Silurian Tuscarora Formation and Clinton Series. The Tuscarora Formation is a resistant, quartz rich sandstone. The Clinton Series is comprised of a hematitic sandstone with shale interbeds, a medium to coarse-grained quartz sandstone, and a silty limestone. The Tuscarora Formation and the Clinton Series are often mapped as one unit due to poor exposure and stratigraphic thinning.

\subsection{Watershed Information}

The USGS identifies three major watersheds within Monroe County with listed 10-digit hydrologic unit codes (HUC): the Upper James (02080201), the Middle New (05050002), and the Greenbrier (05050003). These watersheds are locally divided into the Muddy River, Howards Creek, Second Creek, Greenbrier River, New River, Rich Creek, Potts Creek, Indian Creek and Sweet Springs watersheds. The watersheds directly associated with Peters Mountain are Potts Creek, Second Creek, Indian Creek, Rich Creek and Sweet Springs (Figure 1).

\subsection{Site Location Descriptions}

This study consolidates previous water chemistry and hydrologic data from Monroe County. Previous data collected by Richards (2006) extend from the middle to the northern region of Peters Mountain. Data collection in this study focused on the entire extent of Peters Mountain; some areas of interest overlap with Richards’ data and were included in this research.

A total of 14 springs and caves were included in this study and span from the southern to the northern extent of the county (Figure 3; Table 1; Appendix B). Springs are grouped based on geologic groups, ages, and elevation: (1) clastic springs are located in the interbedded clastic units and sandstone ridges of Peters Mountain in the Reedsville, Juniata, and Tuscarora Formations, (2) carbonate springs are located in the valleys, lower in elevation, and emerge from 
Table 1: Spring Locations and Sampling Frequency

\begin{tabular}{|c|c|c|c|c|c|c|}
\hline Spring Name & $\begin{array}{l}\text { Database } \\
\text { Code }\end{array}$ & $\begin{array}{l}\text { Geologic } \\
\text { Formation }\end{array}$ & $\begin{array}{l}\text { Spring } \\
\text { Grouping }\end{array}$ & \multicolumn{2}{|c|}{ UTM Coordinates Zone 17S } & Elevation (m) \\
\hline \multicolumn{7}{|l|}{ Ridge Springs $^{a}$} \\
\hline Luger & LUGER & Reedsville & Clastic & 550460 & 4152395 & 907 \\
\hline Gap Mills ${ }^{b}$ & GMILL & Reedsville & Clastic & 553283 & 4154045 & 874 \\
\hline Hancock & HANCK & Reedsville & Clastic & 520161 & 4136647 & 782 \\
\hline Olson Peters ${ }^{b}$ & OLSON & Juniata & Clastic & 526239 & 4139250 & 847 \\
\hline Broyles & BROY & Reedsville & Clastic & 530822 & 4142284 & 817 \\
\hline $\begin{array}{l}\text { Sweet Springs } \\
\text { Upper }\end{array}$ & OLDU & Reedsville & Clastic & 567629 & 4164180 & 714 \\
\hline Echols & $\mathrm{ECH}$ & Reedsville & Clastic & 555567 & 4155883 & 876 \\
\hline \multicolumn{7}{|l|}{ Valley Springs ${ }^{a}$} \\
\hline Zenith $^{b}$ & ZEN & Oriskany-Helderberg & Carbonate & 541537 & 4150812 & 667 \\
\hline Dropping Lick & DROPL & Beekmantown & Carbonate & 542176 & 4150538 & 741 \\
\hline Crabtree $^{b}$ & CRABT & New Market & Carbonate & 527430 & 4141264 & 645 \\
\hline Trout Hatchery & НАТСH & New Market & Carbonate & 526483 & 4140742 & 636 \\
\hline Miss Effie & MEFF & Beekmantown & Carbonate & 536393 & 4147714 & 686 \\
\hline Coburn & CBRN & Beekmantown $^{d}$ & Carbonate & 519758 & 4137569 & 585 \\
\hline \multicolumn{7}{|l|}{ Thermal Springs ${ }^{a}$} \\
\hline $\begin{array}{l}\text { Sweet Springs } \\
\text { Pool }^{b}\end{array}$ & OLDSWT & Trenton Black River & Thermal & 567035 & 4165035 & 613 \\
\hline \multicolumn{7}{|l|}{ Discharge $^{c}$} \\
\hline Sweet Creek & QSWT & $\mathrm{n} / \mathrm{a}$ & Surface & 566375 & 4164792 & 612 \\
\hline Second Creek & QSEC & $\mathrm{n} / \mathrm{a}$ & Surface & 551628 & 4157728 & 705 \\
\hline Indian Creek & QIND & $\mathrm{n} / \mathrm{a}$ & Surface & 533663 & 4152353 & 514 \\
\hline Hans Creek & QHAN & $\mathrm{n} / \mathrm{a}$ & Surface & 529893 & 4147664 & 584 \\
\hline Rich Creek & QRCH & $\mathrm{n} / \mathrm{a}$ & Surface & 517725 & 4138802 & 488 \\
\hline
\end{tabular}

${ }^{a}$ springs sampled two times a year in a large sampling event; ${ }^{b}$ "indicator springs" sampled every eight weeks; ${ }^{c}$ discharge taken approximately monthly until a sufficient rating curve was developed; ${ }^{d}$ CBRN GPS coordinates plot in the Brallier Formation but has carbonate chemical signatures. The discrepancy is likely due to poor geologic mapping. 
either the Oriskany-Helderberg, Beekmantown, or New Market Formations, and (3) one thermal spring that emerges from the Trenton/Black River Formation and is associated with the St. Clair thrust fault. Coburn Spring plots in the Brallier Formation based on GPS coordinates, but is considered to be a carbonate spring based on chemical signature. This spring is associated with the Beekmantown Formation in this study.

The majority of the springs and caves in this study are privately owned and discharge from a range of lithologies that control chemical characterizations. A subset of five indicator springs were selected to represent all spring groups and analyzed more frequently for greater temporal resolution. These springs cover the entire extent of Peters Mountain and range in elevation and chemical signatures. The indicator springs include: Gap Mills (mixed-clastic), Olson Peters (mixed-clastic), Zenith (carbonate), Crabtree (carbonate), and Old Sweet (thermal). Four public water supply springs (PWS) are included in this study and span from the southern end of Monroe County, near Peterstown, to the town of Gap Mills. Hancock Spring and Coburn Spring are the public water supply springs for the town of Red Sulphur Springs. The Gap Mills spring is the current public water supply for the town of Gap Mills. Luger spring is the current supply for the town of Union.

Due to the number and configuration of springs on Peters Mountain, directly measuring flow in individual springs is difficult; therefore, total flow associated with the study area was quantified through the measurement of discharge at five major creeks. These discharge locations include four major watersheds in Monroe County and account for all surface water leaving the valley. These creeks flow year-round and are easily accessible for sampling. These locations include: Sweet Spring Creek, Second Creek, Indian Creek, Hans Creek, and Rich Creek. Each discharge location was chosen to encompass as much spring-fed water as possible. This calculation gives insight to the quantity of spring water available from Peters Mountain region for consumption and use.

Detailed site descriptions are located in Appendix B. 


\subsection{Methods}

This research involves analysis of carbonate springs from southeastern to northeastern Monroe County along Peters Mountain. All springs and caves were sampled during major sampling events; indicator springs were sampled more frequently (Table 1).

\subsection{Physical Methods}

\subsubsection{Field Parameters}

A Garmin eTrex 10 GPS unit was used to determine location and elevation at spring and discharge locations. Measurements were made to approximately 9 meter accuracy; limited satellite access in remote spring locations decreased this accuracy slightly.

A YSI Pro multi-meter was used to measure $\mathrm{pH}$, temperature, and $\mathrm{SC}$ at each spring and discharge location. This instrument was calibrated at the start of each day with $\mathrm{pH} 4$ and 7 buffers as well as a $1.413 \mathrm{mS} / \mathrm{cm}$ SC solution.

\subsubsection{Continuous Data Loggers}

ONSET HOBO temperature and/or SC data loggers were placed in all 14 springs from August 2015-March 2018. SC loggers were deployed in the public water supply springs for the entirety of the sampling period and implemented in the remaining springs as additional loggers were purchased. Water level (pressure) loggers were installed in five discharge locations within stainless steel well points beginning in March 2017.

Loggers recorded data every 15 or 30 minutes, depending on deployment, for up to 6 months to measure seasonal variability. ONSET HOBO U24 loggers measure temperature and SC with a resolution of $1 \mu \mathrm{S} / \mathrm{cm}$ and $0.1^{\circ} \mathrm{C}$; U22 and UA-002 loggers measure temperature with a resolution of $0.1^{\circ} \mathrm{C}$ and $0.53^{\circ} \mathrm{C}$, respectively; and $\mathrm{U} 20$ pressure loggers have a resolution of $0.04 \mathrm{kPa}(0.006 \mathrm{PSI})$.

\subsubsection{Discharge}

The 2D Digital SonTek ADV® (Acoustic Doppler Velocimeter) was used to measure discharge by stream profile at all five locations. Flow rates were measured at various locations along a perpendicular transect of the stream using the standard $0.6 \mathrm{x}$ depth average velocity measurement method (Buchanan and Somers, 1969). The meter integrates velocity measurements over 40 seconds. Total discharge is calculated by the sum of all cross-sectional 
velocities multiplied by the cross-sectional area. This instrument is capable of velocity measurements down to $0.2 \mathrm{ft}$. depth cross-sectional areas. Quality control procedures are implemented in the software.

Staff gages were installed at each discharge location to measure stream height (stage) to create stage-discharge rating curves. Stages were adjusted to the maximum depth of each stream (Figure 4) using the following equation:

$$
H_{\text {stream }}=H_{\text {staff }}+O F F_{\text {staff }}
$$

$\mathrm{H}_{\text {staff }}$ is the stage at the staff gauge and was found using the following equation:

$$
H_{\text {staff }}=G-y_{G}
$$

Where $\mathrm{G}$ is the value on the staff gage corresponding to the stream elevation. $\mathrm{yg}_{\mathrm{G}}$ is the value at the bottom of the staff gage, found using:

$$
y_{G}=N-x
$$

Where $\mathrm{N}$ is the large number on the staff gage and where $\mathrm{x}$ is the distance from $\mathrm{N}$ to the bottom of the staff gage. The value $\mathrm{y}_{\mathrm{G}}$ corresponds to the datum for stage at the staff gage.

$\mathrm{OFF}_{\text {staff }}$ is the adjusted value from the elevation of the staff gauge to the maximum depth of the stream profile. $\mathrm{OFF}_{\text {staff }}$ is location dependent and only changes when the staff gage is adjusted or when the stream profile changes. However, stream profile changes were ignored in these calculations. $\mathrm{OFF}_{\text {staff }}$ was calculated by the following equation:

$$
O F F_{\text {staff }}=D-H_{\text {staff }}
$$

Where $\mathrm{D}$ is the maximum depth of the stream profile. D values were chosen based on average stream maximum depths from December 2016; D values were held constant, and assume no changes to the stream profile occurred.

Stainless steel well points were installed adjacent to the staff gages and provided a secure housing for the deployment of the continuous water level loggers. Stage and discharge were measured at the time of water level logger deployment. An additional $\mathrm{H}_{\text {stream }}$ adjustment was necessary to accommodate the elevation of the data logger within the well point when converting logger pressure measurements to continual stages. The following equation is the final adjusted stage $\left(\mathrm{H}_{\text {stream }}\right)$ :

$$
H_{\text {stream }}=H_{\text {logger }}+O F F_{\text {staff }}+O F F_{\text {logger }}
$$


a)

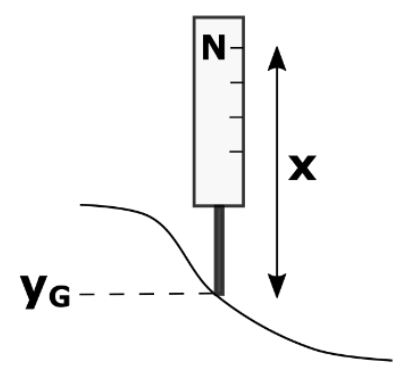

b)

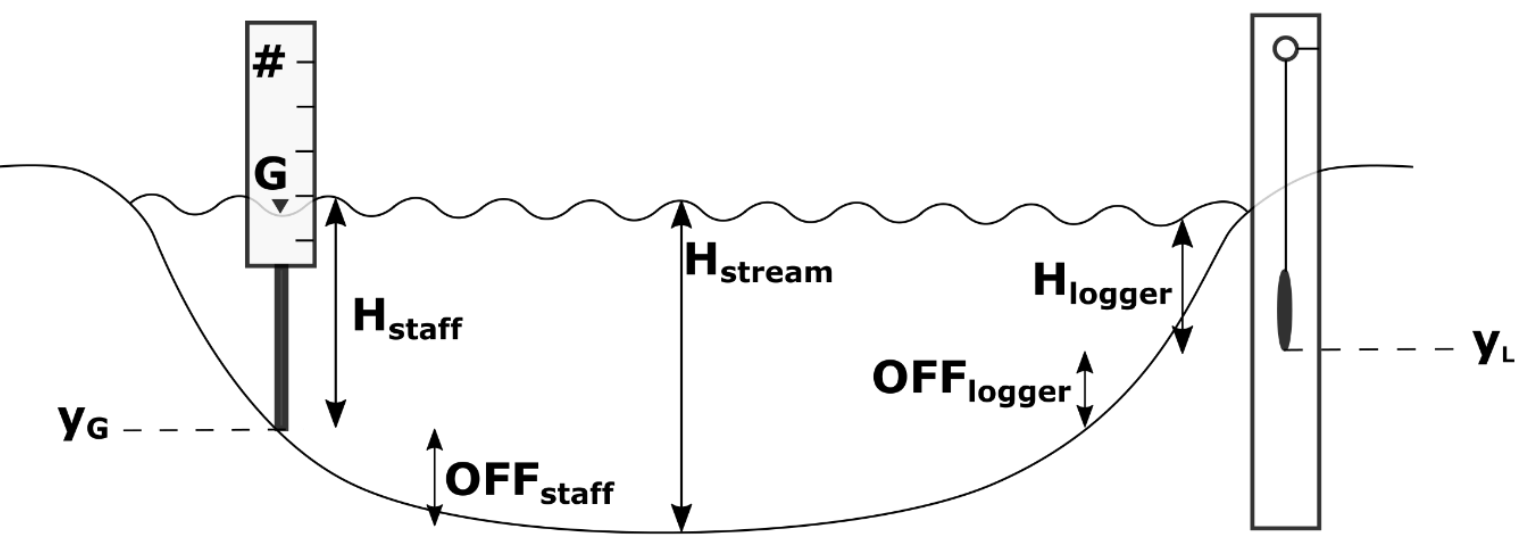

Figure 4: a) Schematic to calculate the staff gage datum (yG) at all installation locations. b) Schematic to calculate adjusted stages to stream morphology. Adjusted stages ( $\left.H_{\text {stream}}\right)$ are calculated by adding the stage at the staff gage $\left(\mathrm{H}_{\text {staff }}\right)$ to adjustments for the stream profile depth $\left(\mathrm{OFF}_{\text {staff }}\right)$. Continuous pressure transducer data were also adjusted for the elevation of the logger relative to $\mathrm{H}_{\text {stream }}\left(\mathrm{OFF}_{\text {logger }}\right)$. 
Where $\mathrm{OFF}_{\text {logger }}$ is the adjusted logger position. $\mathrm{OFF}_{\text {logger }}$ is adjusted any time the logger is removed from the well point for download. Data logger position within the well point casing was verified during discharge data collection using the following equation:

$$
O F F_{\text {logger }}=H_{\text {staff }}-H_{\text {logger }}
$$

Where $\mathrm{H}_{\text {logger }}$ is the stage associated with the water pressure measured by the logger.

Stage-discharge curves were created for each stream location. This relationship allows for the determination of discharge at any stage, measured continuously by the water level loggers. At least five separate stage-discharge measurements were included to provide a range for creating the curve. Discharges at the five stream locations were summed for an estimate of total discharge from Peters Mountain.

Discharge data for all five locations are tabulated in Appendix C.

\subsection{Chemical Methods}

Samples underwent various laboratory analyses (Table 2).

\subsubsection{Cations and Anions}

Inductively coupled plasma optical emission spectroscopy (ICP-OES) was used to measure major and trace elements. Elemental distribution and quantification are determined by emission at different wavelengths after being excited by plasma. "Dissolved" elemental samples were filtered with a $0.45-\mu \mathrm{m}$ filter and preserved with trace metal grade $\mathrm{HNO}_{3}$ to prevent precipitation, the sorption of ions to the walls of the container, and degradation reactions. In March 2016, all spring samples were analyzed for major cations in both digested and filtered samples to determine whether major analytes were preferentially in a dissolved or suspended phase. There was no significant difference measured between sample preparations in the majority of the analytes (Figure 5). Elements that result in concentrations that deviate from the digested-filtered parity line are not found consistently, and only exist in two samples: QIND and QHAN on 10/08/2016. These deviations are likely influenced by low concentrations in the sample. Overall, the data show no difference between filtered and digested cation analysis at these locations. Only filtered samples were analyzed for the remainder of this study. The samples were analyzed by Geoscience Laboratories in Ontario, Canada. 
Table 2: Laboratory Analysis

\begin{tabular}{|c|c|c|c|c|c|}
\hline Analyte & $\begin{array}{l}\text { Bottle } \\
\text { Size }\end{array}$ & $\begin{array}{l}\text { Number } \\
\text { of Bottles }\end{array}$ & Preservative & Filtered/Raw & Analytical Method \\
\hline Anions & $125 \mathrm{~mL}$ & 1 & No & Filtered $b$ & $\mathrm{IC}^{c}$ \\
\hline $\begin{array}{l}\text { Dissolved } \\
\text { Elements }\end{array}$ & $125 \mathrm{~mL}$ & 1 & $\mathrm{HNO}_{3}{ }^{a}$ & Filtered ${ }^{b}$ & ICP-OES $^{d}$ \\
\hline $\begin{array}{l}\text { Digested } \\
\text { Elements }\end{array}$ & $125 \mathrm{~mL}$ & 1 & $\mathrm{HNO}_{3}{ }^{a}$ & Raw & $\mathrm{ICP}-\mathrm{OES}^{d}$ \\
\hline NPOC $^{e}$ & $40 \mathrm{~mL}$ & 3 & No & Raw & Shimadzu \\
\hline Alkalinity & $250 \mathrm{~mL}$ & 1 & No & Raw & Titration \\
\hline $\begin{array}{l}\text { Total and } \\
\text { Fecal } \\
\text { Coliforms }\end{array}$ & $100 \mathrm{~mL}$ & 1 & No & Raw & IDEXX Colilert $^{\circledR}$ \\
\hline
\end{tabular}

${ }^{a}$ trace-metal grade preservative; ${ }^{b} 0.45-\mu \mathrm{m}$ filter; ${ }^{c}$ Ion Chromatography at NRCCE at WVU; ${ }^{d}$ Inductively

Coupled Plasma Optical Emission Spectroscopy at Geolabs in Ontario Canada; ${ }^{e}$ Non Purgable Organic Carbon 


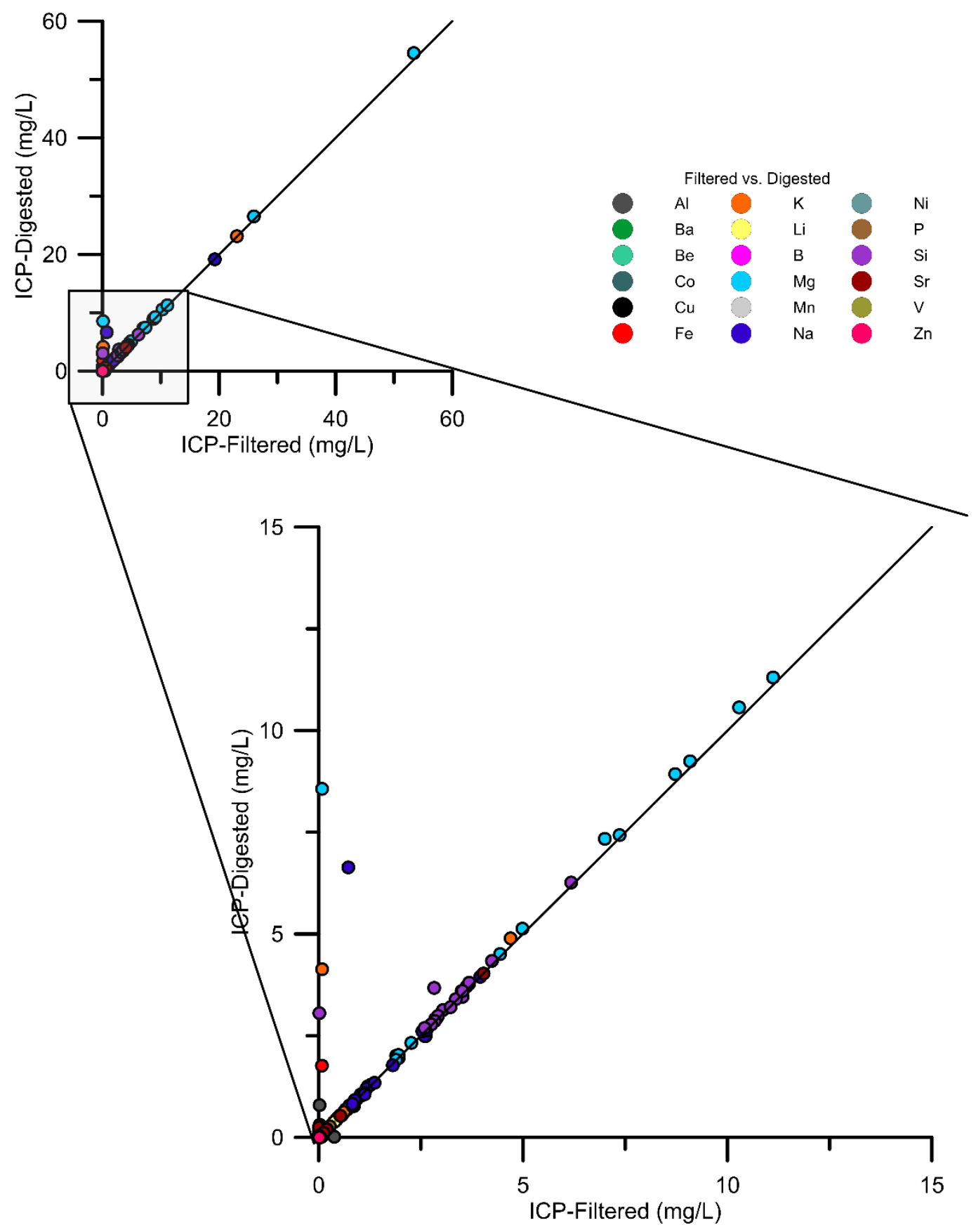

Figure 5: ICP-OES filtered vs. digested cation analysis results from March, 2016. A 1:1 parity line is displayed in black. 
The anions $\mathrm{SO}_{4}{ }^{2-}, \mathrm{NO}_{3}{ }^{-}$and $\mathrm{Cl}^{-}$were analyzed using ion chromatography (IC). Ion chromatography separates charged molecules in solution based on their size and chemical characteristics. The sample is passed through a column where the charged species sorb. The retention time on the column of the charged species identifies the chemical species. Samples for anion analysis were filtered and were not acid preserved. Ion chromatography analysis was completed at the National Research Center for Coal and Energy (NRCCE) at West Virginia University.

\subsubsection{Alkalinity}

Alkalinity was measured in the laboratory using either a manual Hach digital titrator with sulfuric acid or with a Hanna Instrument 900 Series auto-titrator with various acid concentrations. The Hach digital titrator was used on samples from 12/2/2016 to 4/30/2017 with $50 \mathrm{~mL}$ of sample and were titrated to $\mathrm{pH} 4.2$ and $\mathrm{pH} 3.9$; alkalinity was determined using the Gran 2-point titration calculation. The Hanna Instrument 900 Series digital titrator was used on samples from 6/30/2017 to 9/13/2017. Alkalinity was determined using extracted auto-titrator data and the USGS online inflection point alkalinity calculator (Alkalinity Calculator, 2013). The auto-titrator has a dosing error of $0.1 \%$ of the burette volume and a $\mathrm{pH}$ accuracy of 0.001 . Alkalinity is reported as meq/L.

\subsubsection{Bacterial Indicators}

Water samples were tested for total coliforms and E. coli using the Colilert ${ }^{\circledR}$ Quanti-Tray test kit. A most probable number (MPN) bacterial count up to 2,419 per $100 \mathrm{~mL}$ sample was identified with 95\% confidence (Colilert $\left.{ }^{\circledR}, 2016\right)$. Discharge locations and select spring samples were diluted if previous values exceeded the maximum method detection limit. The reported calculations account for dilution factors when necessary. Due to travel to the field site, analysis was completed within 24 hours of sample collection on two-day sampling trips and within 48 hours on 3-day sampling trips.

This quantification process uses the metabolic activity of coliform and E. coli bacteria to determine bacterial counts. Growth of these bacteria are controlled using defined substrate methodology (DSM), in the presence of two known complex carbon compounds under chromogenic and fluorogenic substrate conditions (Yakub et al., 2002). Coliforms use the 
enzyme $\beta$-galactosidase to metabolize one carbon compound and release o-nitrophenyl. The onitrophenyl produces a perceivable yellow color. E. coli uses the enzyme $\beta$-glucuronidase to metabolize the second carbon compound which releases 4-methylumbelliferone. The 4methylumbelliferone creates fluorescence detectable under 365-nm UV light. Other organisms that contain the same enzymes are suppressed by the matrix of Colilert ${ }^{\circledR}$ to prevent false positives.

Analysis began with the combination of $100 \mathrm{~mL}$ of the sample and the Colilert ${ }^{\circledR}$ reagent. This solution was poured into the tray and fed through the Quanti-Tray Sealer Plus. The samples were incubated for 24 hours at $35^{\circ} \mathrm{C}$ in a Binder microbiological incubator. The Quanti-Tray samples were then counted for the presence of yellow color and fluorescence; a positive result for total coliforms and E. coli, respectively. Samples were incubated for an additional 4 hours if color and fluorescence were not vibrant. Comparison to a factory calibrated comparator was completed only if results were still questionable after additional incubation. Total incubation time never exceeded 28 hours. The wells were marked with clear directional markings to avoid mistakes in counts. A MPN software was used in place of the tangible table to quantify the amount of total coliforms and E. coli in each sample and avoid manual error.

\subsubsection{Non-purgable organic carbon (NPOC)}

NPOC samples were collected in $40 \mathrm{~mL}$ vials and analyzed in replicates of three with a Shimadzu TOC-V carbon analyzer. The automatic sampler extracts a specified volume of sample connected to a syringe. The automatic sampler contains a maximum of $6840-\mathrm{mL}$ vials. NPOC is calculated by first purging the sample with acid to remove the dissolved inorganic carbon (DIC). The sample is then passed into a combustion tube with a platinum catalyst and heated to $720^{\circ} \mathrm{C}$. The sample then passes through the near dispersed infrared (NDIR) sensor and NPOC is determined.

\subsubsection{Ionic Strength, $\mathbf{P}_{\mathrm{CO} 2}$, and Mineral Saturation Indices}

Ionic strength, ion activity, $\mathrm{P}_{\mathrm{CO} 2}$, and saturation indices for minerals of interest were calculated from the chemical data using PHREEQC software (Parkhurst and Appelo, 1990). 


\subsection{Quality Control}

Quality control samples were taken to measure the effect of error in sampling, handling and laboratory analyses. Sample duplicates were selected at random. Approximately one in every 20 samples or one sample per sampling event were duplicates. Equipment blanks were incorporated in laboratory analyses. All sampling procedures were followed in the preparation of the duplicates and equipment blanks.

The following parameters were used to calculate percent difference for duplicate samples (13 samples) and presence/absence for equipment blanks (2 samples): $\mathrm{Ca}^{2+}, \mathrm{Mg}^{2+}, \mathrm{Na}^{+}, \mathrm{K}^{+}, \mathrm{Cl}^{-}$, $\mathrm{SO}_{4}{ }^{2-}$, and alkalinity. For all major ions considered, $89 \%$ of the duplicates have a less than $10 \%$ difference; however, the OLDU duplicate on March 10, 2017 is above $10 \%$ for $\mathrm{Mg}^{2+}, \mathrm{Na}^{+}, \mathrm{K}^{+}$, and $\mathrm{SO}_{4}{ }^{2-}$. Alkalinity in the duplicate samples had a percent difference less than $1 \%$. Field blanks had three detections of major ions and two detections of alkalinity; when detection occurred, it was at concentrations at least an order of magnitude less than typical spring samples in this study (Table 3). Therefore, contamination from equipment is considered to be negligible.

Manual alkalinity titrations were completed on average within 10 days of sample collection; alkalinity titrations measured with the auto-titrator were completed on average within 3 days of sample collection (lost data in December 2017 and re-titrations were not included in averages). Overall charge balance errors were $~ 5 \%$ lower in samples where alkalinity was measured using the auto-titrator at times soon after sample collection. To test the stability of alkalinity samples, additional samples taken on 2/9/2018 were tested within 24 hours of sample collection and compared to titrations completed 9 and 35 days after sample collection. Comparisons were done at three spring locations representing a range of alkalinities (ZEN, OLDSWT, and HATCH); the change in measured alkalinity was less than 8\%. Alkalinity at all locations in this study is considered to be stable after sample collection.

Charge balance was calculated to validate the chemical analysis and to ensure no major ions in solution were overlooked. The charge balance for accepted data were within $\pm 10 \%$. 
Table 3: Quality Control Analysis for Field Blank

\begin{tabular}{lllrrrrrrr}
$\begin{array}{l}\text { Sample } \\
\text { ID }\end{array}$ & $\begin{array}{l}\text { Sample } \\
\text { Type }\end{array}$ & Date & $\begin{array}{r}\mathbf{C a}^{2+} \\
(\mathbf{m g} / \mathbf{L})\end{array}$ & $\begin{array}{r}\mathbf{M g}^{2+} \\
(\mathbf{m g} / \mathbf{L})\end{array}$ & $\begin{array}{r}\mathbf{N a}^{+} \\
(\mathbf{m g} / \mathbf{L})\end{array}$ & $\begin{array}{r}\mathbf{K}^{+} \\
(\mathbf{m g} / \mathbf{L})\end{array}$ & $\begin{array}{r}\mathbf{C l}^{-} \\
(\mathbf{m g} / \mathbf{L})\end{array}$ & $\begin{array}{r}\mathbf{S O}^{2-} \\
(\mathbf{m g} / \mathbf{L})\end{array}$ & $\begin{array}{r}\text { Alkalinity } \\
(\mathbf{m e q} / \mathbf{L})\end{array}$ \\
\hline \hline WVU & Field Blank & $8 / 27 / 2017$ & 0.08 & $<0.08$ & $<0.72$ & 0.66 & $<0.035$ & $<0.034$ & 0.25 \\
WVU & Field Blank & $9 / 12 / 2017$ & 0.16 & $<0.08$ & $<0.72$ & $<0.08$ & $<0.035$ & $<0.034$ & 0.03 \\
\hline MDL $^{a}$ & & n/a & $<0.035$ & $<0.08$ & $<0.72$ & $<0.08$ & $<0.035$ & $<0.034$ & \\
Average Sample & & n/a & 43.4 & 8.58 & 2.74 & 1.22 & 3.15 & 7.83 & 2.36 \\
\hline \hline
\end{tabular}

Top panel are field blanks; bottom panel are ${ }^{a}$ method detection limits (MDL) typical for ICP-OES analysis and ${ }^{b}$ average samples taken from all springs except OLDSWT because of its extreme chemistry; missing cells are data not collected 


\subsection{Results}

\subsection{Spatial Distribution and Characterization of Springs}

Monroe County has over 300 mapped spring and cave locations (Hemple, 1975;

McColloch, 1986; Richards, 2006); spring distribution and cave formation along Peters Mountain are controlled by elevation and geology. The distribution of springs along Peters Mountain varies from 560 to $1080 \mathrm{~m}$ in elevation; the majority of springs flow from 800 to 1,000 $\mathrm{m}$ in elevation (Figure 6). Most springs emerge from the Reedsville Formation and the valley carbonate formations. The number of springs mapped in the Reedsville is likely due to the contact between the calcareous clastic unit (Reedsville Formation) and the medium bedded limestone (Trenton/Black River Formation) or different permeability layers within the Reedsville. High elevation formations on Peters Mountain (Tuscarora and Clinton) tend to have low frequencies of spring emergence. The majority of caves along Peters Mountain are associated with the Beekmantown and New Market Formations (Figure 7). These valley formations have a mix of autogenic and allogenic recharge and have similar numbers of caves and springs (Figure 7).

Springs in this study are broken into three generalized categories: clastic, carbonate and thermal that correspond to the lithologies identified previously (Figure 8). The carbonate springs are located in the valley at lower elevation in the Oriskany-Helderberg, Beekmantown and New Market Formations. Clastic springs emerge from interbedded siliciclastic and carbonate units in the Reedsville and Juniata Formations on the mountain flanks. The one thermal spring in the study area emerges from the Trenton/Black River Formation and is likely associated with the St. Clair thrust fault. It is important to note that these spring categories are generalized and do not account for heterogeneity within lithologies.

\subsection{Field Measurements}

Chemistry of 13 springs (including five indicator springs) was monitored from Fall 2015 until December 2017; all springs were sampled approximately twice a year and indicator springs were sampled at least every eight weeks (Appendix D). Temperature, pH, SC, and alkalinity vary in springs depending on geologic formation and spring group (Table 4, Figure 9).

With respect to temperature, the most seasonally variable springs are in the New Market Formation (CRABT and HATCH) and the most consistent are in the Beekmantown and 


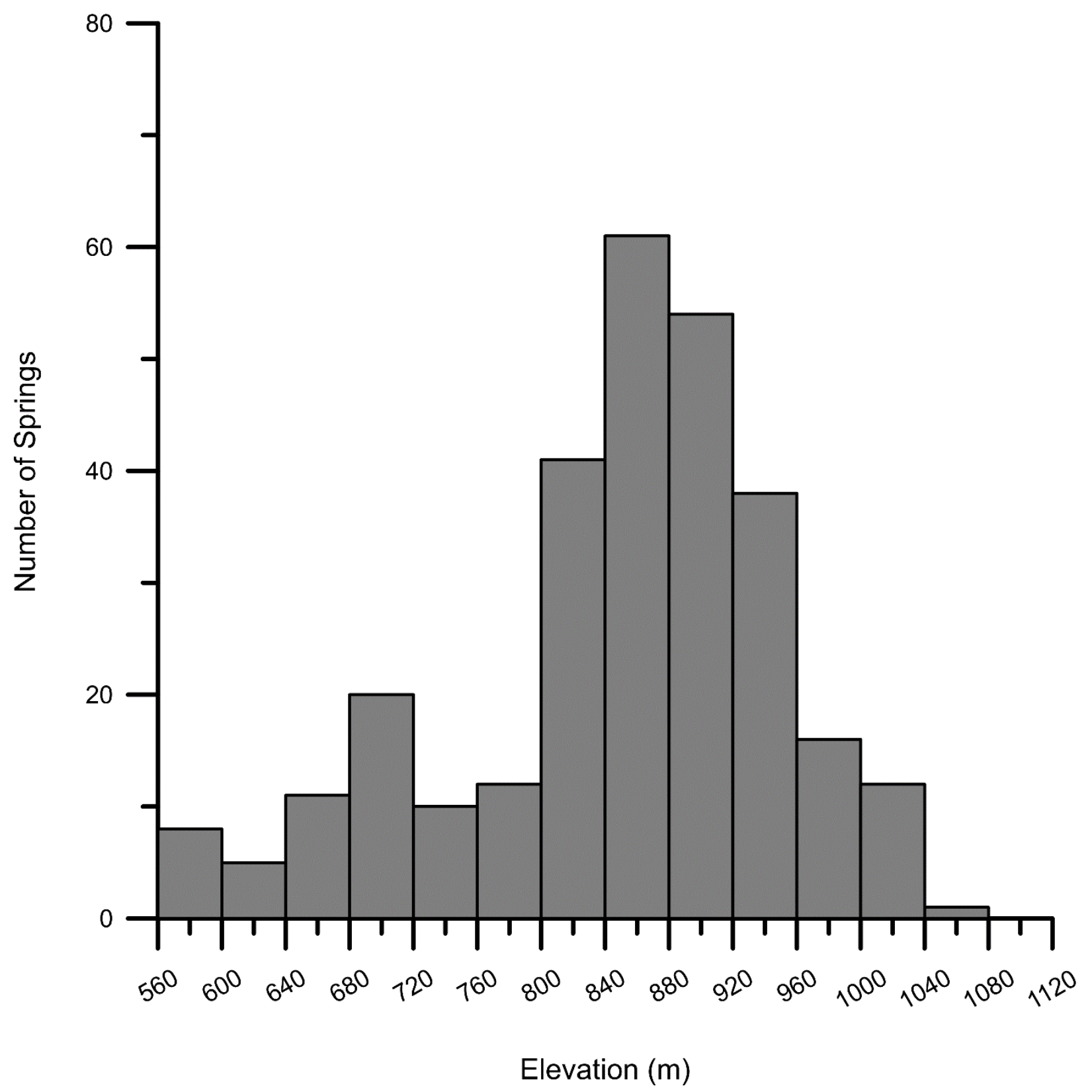

Figure 6: Spatial distribution of springs by elevation along Peters Mountain, WV. Data are compiled from this study, Richards (2006), and Springs of West Virginia (1986). 




Figure 7: Cave and spring distribution by formation along Peters Mountain, WV. Tuscarora and Clinton Formations are grouped together in this study. Data are sourced from this study, Richards (2006), Springs of West Virginia (1986), and Caves and Karst of Monroe County, WV (1975). 


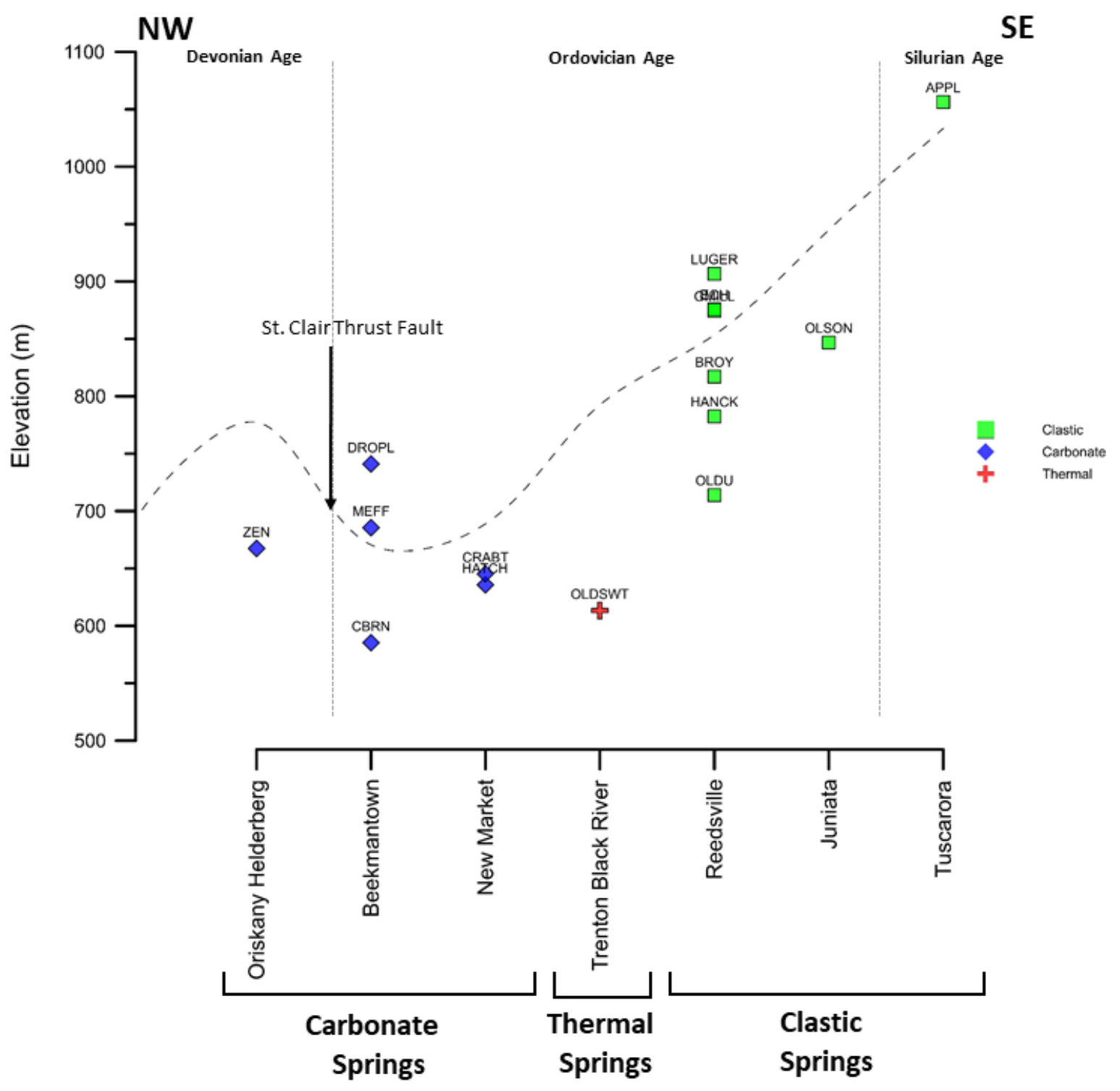

Figure 8: Schematic figure illustrating the general relationships between elevation, formation and spring group in this study. The springs are broken into three groups based on formation: carbonate, thermal, and clastic. GMILL and ECH plot on top of each other but are two separate clastic springs. APPL spring is not included in this study but is added here to mark the formation associated with the top of Peters Mountain. The vertical thin dotted lines mark the Devonian, Ordovician and Silurian age formations. The thick dotted line marks an approximate elevation profile estimated from Google Earth. This profile was taken from NE to SW just south of the town of Lindside. The surface exposure of the St. Clair thrust fault is marked with a dark arrow. Note, spring deviations from this approximate profile are due to elevation heterogeneity along the extent of the mountain. 
Table 4: Meter Data Statistics

\begin{tabular}{|c|c|c|c|c|c|c|}
\hline Location & $\begin{array}{r}\text { Average } \\
\text { Temp. } \\
\left({ }^{\circ} \mathrm{C}\right)\end{array}$ & $\begin{array}{r}\text { Temp. } \\
\text { Standard } \\
\text { Deviation }\end{array}$ & $\begin{array}{r}\text { Average } \\
\mathbf{p H}\end{array}$ & $\begin{array}{r}\text { pH } \\
\text { Standard } \\
\text { Deviation }\end{array}$ & $\begin{array}{r}\text { Average } \\
\text { SC } \\
(\mathrm{mS} / \mathrm{cm})\end{array}$ & $\begin{array}{r}\text { SC } \\
\text { Standard } \\
\text { Deviation }\end{array}$ \\
\hline \multicolumn{7}{|l|}{ Clastic } \\
\hline HANCK & 11.4 & 2.48 & 7.37 & 0.574 & 0.219 & 0.054 \\
\hline $\mathrm{ECH}$ & 9.66 & 0.237 & 7.62 & 0.679 & 0.152 & 0.024 \\
\hline BROY & 10.6 & 0.600 & 7.25 & 0.461 & 0.237 & 0.069 \\
\hline OLSON & 10.4 & 1.97 & 6.94 & 0.504 & 0.136 & 0.043 \\
\hline GMILL & 9.58 & 0.518 & 7.28 & 0.413 & 0.129 & 0.026 \\
\hline OLDU & 10.7 & 0.890 & 7.50 & 0.693 & 0.253 & 0.019 \\
\hline LUGER & 8.93 & 0.061 & 7.67 & 0.531 & 0.122 & 0.024 \\
\hline \multicolumn{7}{|l|}{ Carbonate } \\
\hline НАТСН & 12.3 & 2.97 & 7.27 & 0.507 & 0.229 & 0.076 \\
\hline CBRN & 11.4 & 1.54 & 7.30 & 0.548 & 0.360 & 0.082 \\
\hline CRABT & 11.2 & 2.45 & 6.82 & 0.348 & 0.284 & 0.041 \\
\hline DROPL & 10.4 & 3.98 & 7.49 & 0.357 & 0.226 & 0.054 \\
\hline ZEN & 11.4 & 0.901 & 7.17 & 0.259 & 0.440 & 0.121 \\
\hline MEFF & 10.6 & 1.01 & 7.46 & 0.312 & 0.228 & 0.052 \\
\hline \multicolumn{7}{|l|}{ Thermal } \\
\hline OLDSWT & 21.3 & 0.701 & 6.38 & 0.135 & 1.69 & 0.248 \\
\hline \multicolumn{7}{|l|}{ Discharge } \\
\hline QHAN & 13.8 & 8.18 & 7.67 & 0.332 & 0.300 & 0.121 \\
\hline QIND & 13.3 & 6.20 & 8.01 & 0.284 & 0.263 & 0.073 \\
\hline QRCH & 13.8 & 6.27 & 8.02 & 0.410 & 0.273 & 0.073 \\
\hline QSEC & 12.3 & 4.32 & 7.90 & 0.392 & 0.236 & 0.086 \\
\hline QSWT & 12.6 & 2.47 & 7.09 & 0.408 & 0.363 & 0.125 \\
\hline
\end{tabular}

Temp.= Temperature; SC= Specific Conductance

The temperature data from OLDSWT may not fully reflect the ground water temperature due to the influence of the spring pool and surface water input. 

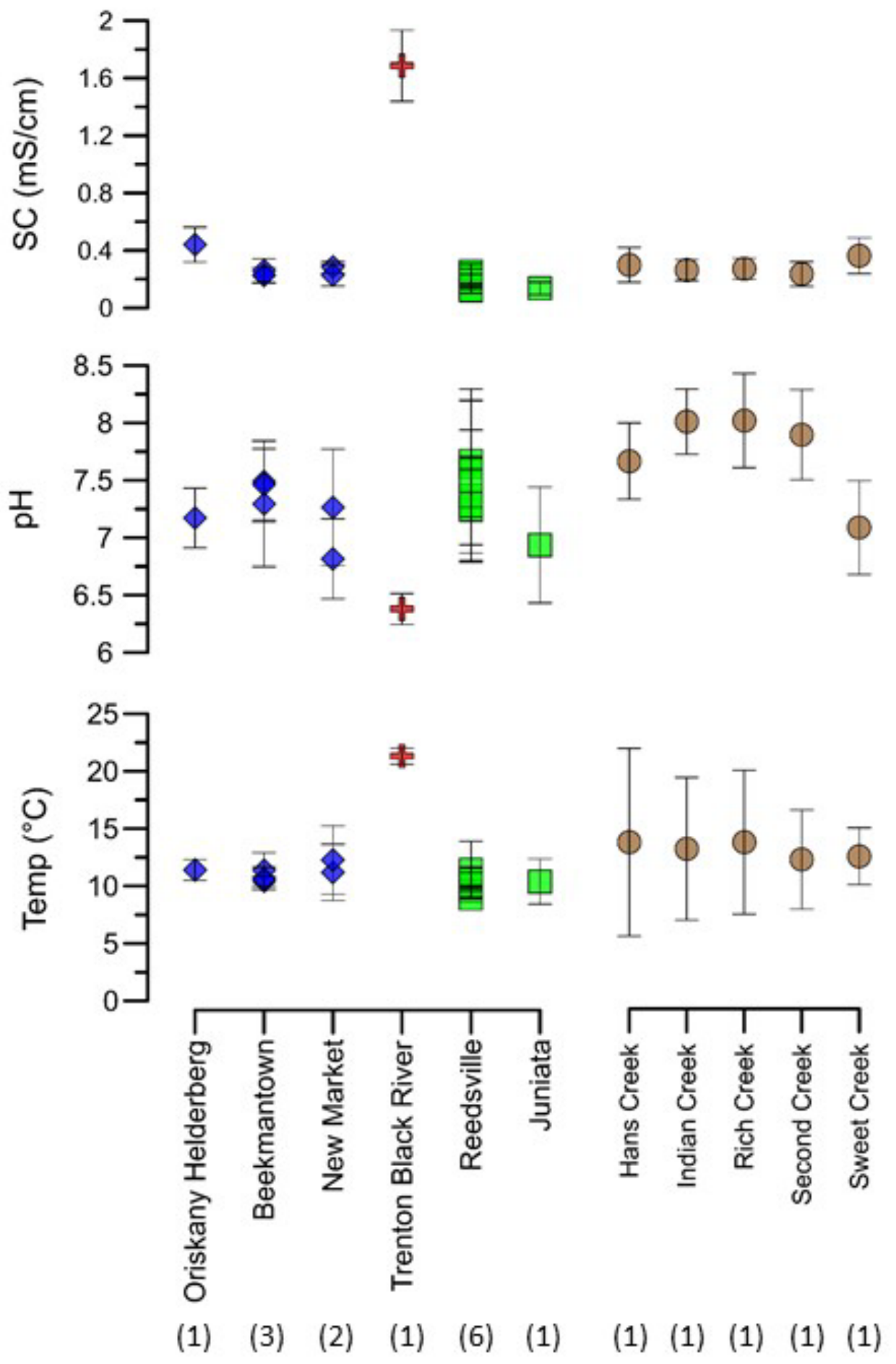

Figure 9: Temperature, $\mathrm{pH}$, and SC for all locations from September 2015 to December 2017. Springs are plotted by formation and discharge locations are plotted by name. The number of locations are indicated below the corresponding names. Standard deviations are marked with error bars. Data symbols are spring groups and discharge locations. 
Oriskany-Helderberg Formations (DROPL and ZEN). Clastic springs are the lowest in temperature and are relatively time-invariant. These springs tend to occur at high elevation and may have longer interaction times with the surrounding rock, resulting in thermal equilibrium. They reflect seasonal rainfall temperatures and are slightly warmer in summer and cooler in winter. Carbonate springs have a range of average temperatures and are the most variable; however, ZEN is temperature consistent and fluctuates less than $1^{\circ} \mathrm{C}$ annually. The thermal spring has the highest average temperature likely associated with deeper flow along the St. Clair thrust fault. The temperature data from OLDSWT is unlikely to be representative of the actual ground water temperature. Instead, it likely reflects the combination of spring water temperature, interactions in the spring pool, and possible flow from the hard surfaces surrounding the spring pool. The data has been included in the report for comparison but should only be used for that purpose.

Discharge locations contain a mixed temperature signature from all contributing springs and are typically highly variable, except for QSWT. Overall discharge temperature variability is likely due to runoff contribution and rapid recharge during rain events. QSWT has similar temperature variability to the carbonate springs. Although average temperatures do not vary by spring groups, geologic differences likely control the "plumbing” of each system (connection to the surface), and thus affect temperature.

The $\mathrm{pH}$ ranges from 6.1 to 8.5 throughout the study area. Clastic and carbonate springs have similar ranges of neutral pH (Figure 10). Discharge locations show slightly higher average $\mathrm{pH}$ than springs attributed to $\mathrm{CO}_{2}$ degassing. Variability in spring $\mathrm{pH}$ is evident in all geologic formations and discharge locations. The lowest and most consistent $\mathrm{pH}$ spring is OLDSWT; this is attributed to high concentrations of dissolved $\mathrm{CO}_{2}$ derived from deep thermal input. Pronounced $\mathrm{pH}$ differences between CRABT (6.82) and HATCH (7.27) occur within the New Market Formation although these springs outcrop approximately $1 \mathrm{~km}$ from each other. It is possible that these differences are due to flow regimes; HATCH is more likely to be connected to a regional flow regime based on recent mapping efforts (Dasher et al., 2018). SC varies based on spring group: clastic springs have low SC, carbonate springs have slightly higher SC, and the thermal spring has the highest SC (Table 4). Discharge locations have SC within the same range as the clastic and carbonate springs. SC in all geologic formations, except the thermal springs, range from $0.07 \mathrm{mS} / \mathrm{cm}$ to $0.75 \mathrm{mS} / \mathrm{cm}$. The high 

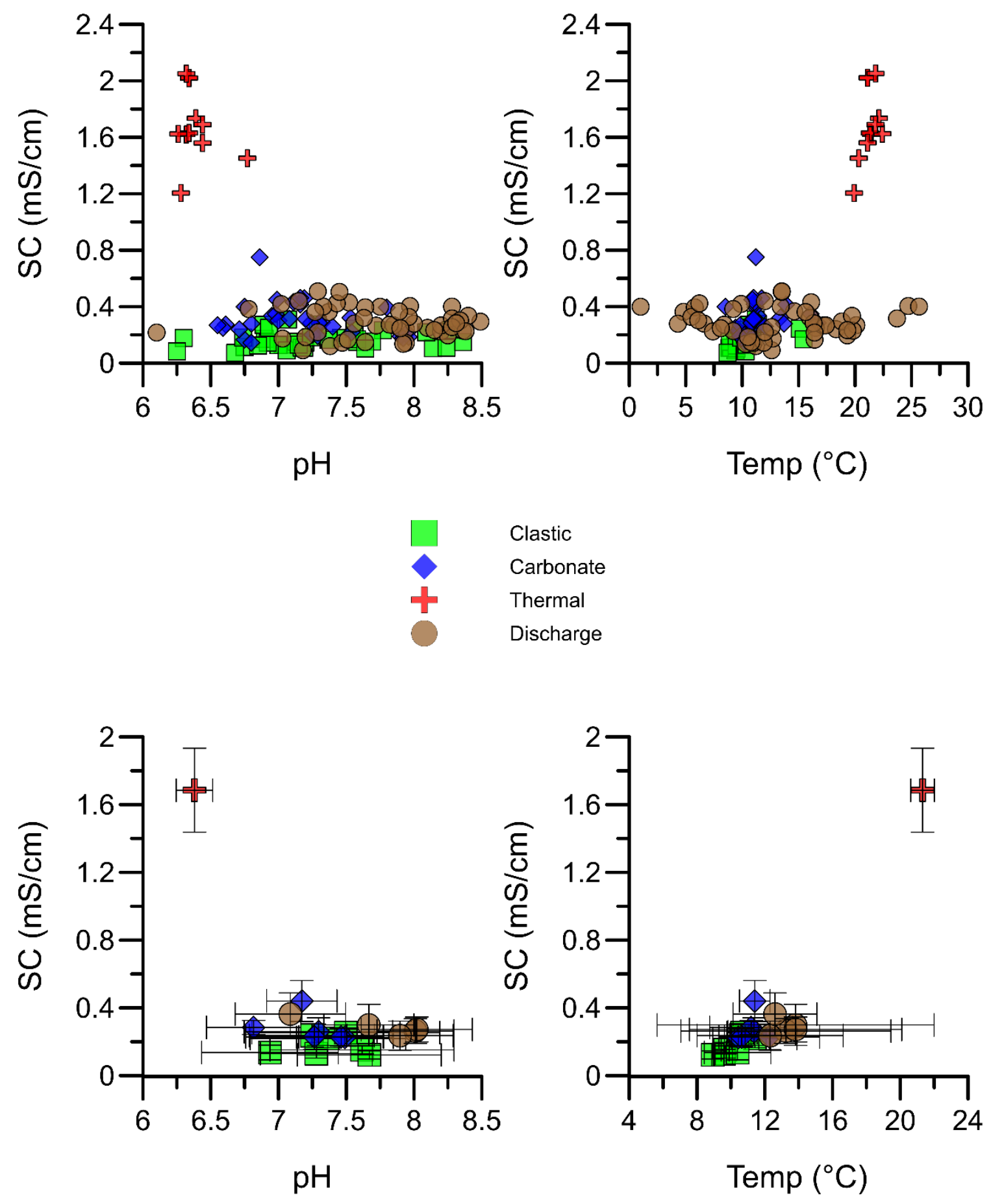

Figure 10: pH, Temp, and SC at all locations. Error bars are standard deviations. Data symbols are spring groups and discharge locations. 
average SC seen in the thermal spring (OLDSWT) may be explained by the high concentrations of $\mathrm{Ca}^{2+}, \mathrm{Mg}^{2+}$, and $\mathrm{SO}_{4}{ }^{2-}$ due to the input of deep water. The variability may be an effect of runoff from paved areas surrounding the spring-pool enclosure. The water sample was collected near the discharge location for the pool and reflects the whole pool temperature and not the spring water source.

\subsection{Chemistry}

Chemical data were evaluated for major contributing cations and anions using Piper plots for all spring and discharge locations (Figure 11). The clastic springs have high proportions of $\mathrm{Ca}^{2+}$ and $\mathrm{HCO}_{3}{ }^{-}$ions. Some clastic springs have slightly elevated $\mathrm{Na}^{+}, \mathrm{K}^{+}$, and $\mathrm{Cl}^{-}$(between 0$20 \%$ ) relative to all clastic springs. OLSON spring consistently has the highest percentages of $\mathrm{SO}_{4}{ }^{2-}$ and $\mathrm{Cl}^{-}$of all the clastic springs. OLSON spring flows from the contact of the Juniata and Reedsville Formations in the southern extent of Peters Mountain. The elevated $\mathrm{SO}_{4}{ }^{2-}$ may be a direct rainfall signature in a system with a small spring-shed. Carbonate springs have high percentages of $\mathrm{Ca}^{2+}$ and $\mathrm{Mg}^{2+}$. Both clastic and carbonate springs can be classified as calciummagnesium-bicarbonate waters on a Piper plot (Figure 11). The thermal spring has percentages of $\mathrm{Ca}^{2+}$ and $\mathrm{Mg}^{2+}$ similar to the other springs, but also has elevated percentages of $\mathrm{SO}_{4}{ }^{2-}(\sim 40 \%)$ and thus can be classified as calcium-magnesium-sulfate-carbonate waters. The source of $\mathrm{SO}_{4}{ }^{2-}$ is likely from deeper thermal flow along the St. Clair thrust fault. Discharge locations have similar proportions of cations and anions as the clastic and carbonate springs and are likely a combined signature. Elevated $\mathrm{SO}_{4}{ }^{2-}, \mathrm{B}$, and $\mathrm{Li}^{2+}$ concentrations are seen in QHAN could potentially indicate the presence of deeper waters associated with upwelling St. Clair thrust fault associated waters in the southern end of the county, but temperature data do not confirm this.

Carbonate, clastic, and discharge locations all have overlapping ranges of $\mathrm{Ca}^{2+}$ and $\mathrm{Mg}^{2+}$ concentrations. $\mathrm{Ca} / \mathrm{Mg}$ molar ratios provide a better insight to the separation between these groups (Figure 12). Clastic spring $\mathrm{Ca} / \mathrm{Mg}$ molar ratios are the most variable ( $\sim 5-30)$. Carbonate spring $\mathrm{Ca} / \mathrm{Mg}$ molar ratios can be broken into two groups based on lithology: dolomite spring waters have ratios around 1; limestone spring waters have higher ratios. ZEN is the only carbonate spring with a clear dolomitic $\mathrm{Ca} / \mathrm{Mg}$ signature. DROPL may have some dolomitic input based on its $\mathrm{Ca} / \mathrm{Mg}$ ratio (1.57). The thermal spring $\mathrm{Ca} / \mathrm{Mg}$ ratio is also similar to limestone spring ratios, however this spring can be separated by its elevated concentrations of 


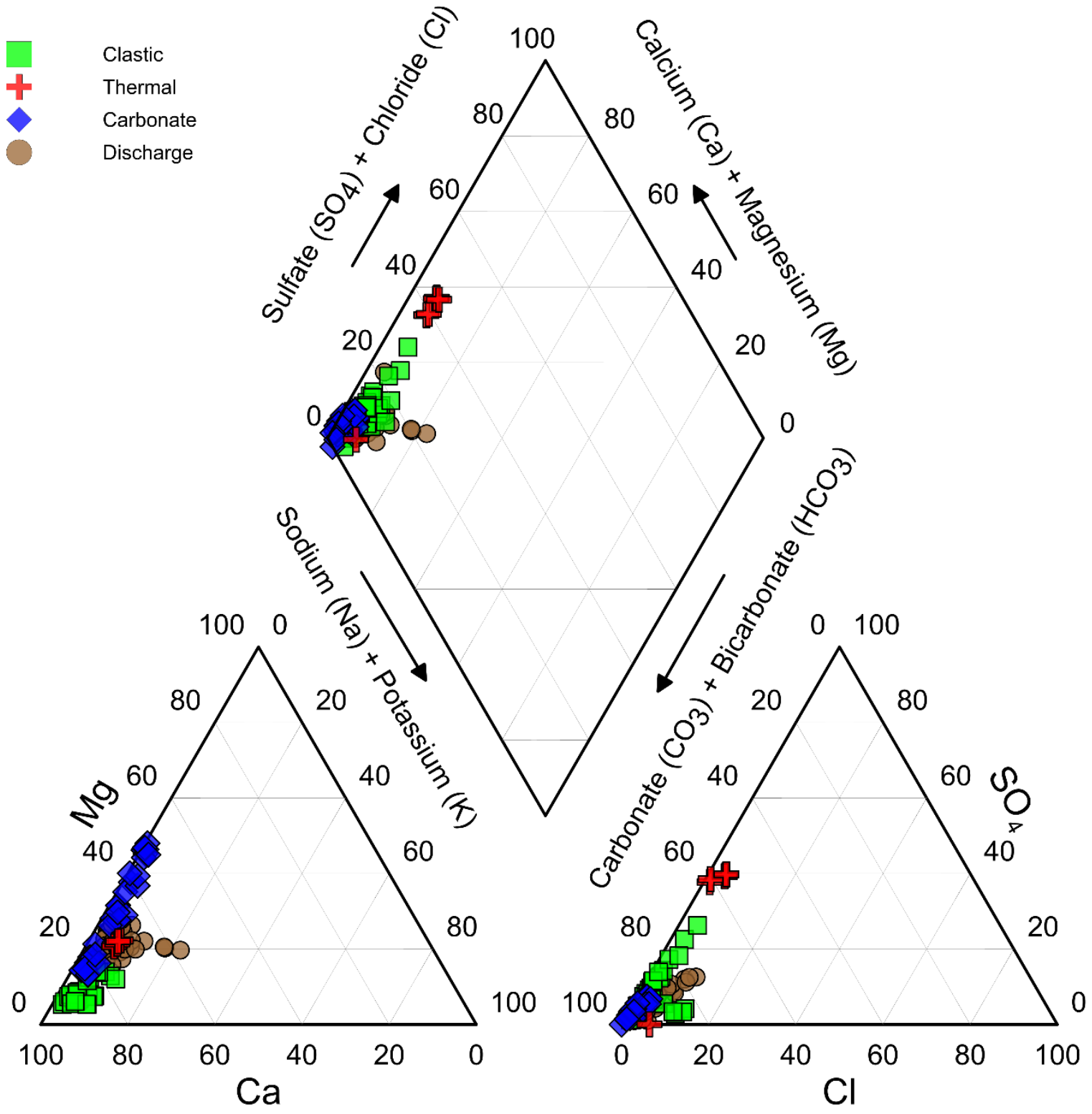

Figure 11: Major cation and anion piper plot for all locations. Samples were gathered from September 2015 to December 2017. Data symbols are spring groups and discharge locations. Samples with charge balances greater than $\pm \mathbf{1 0} \%$. 
a)

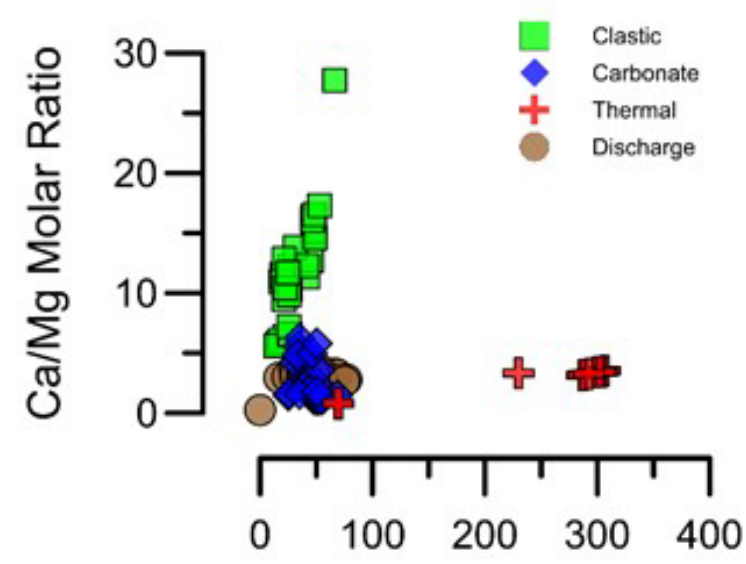

b)

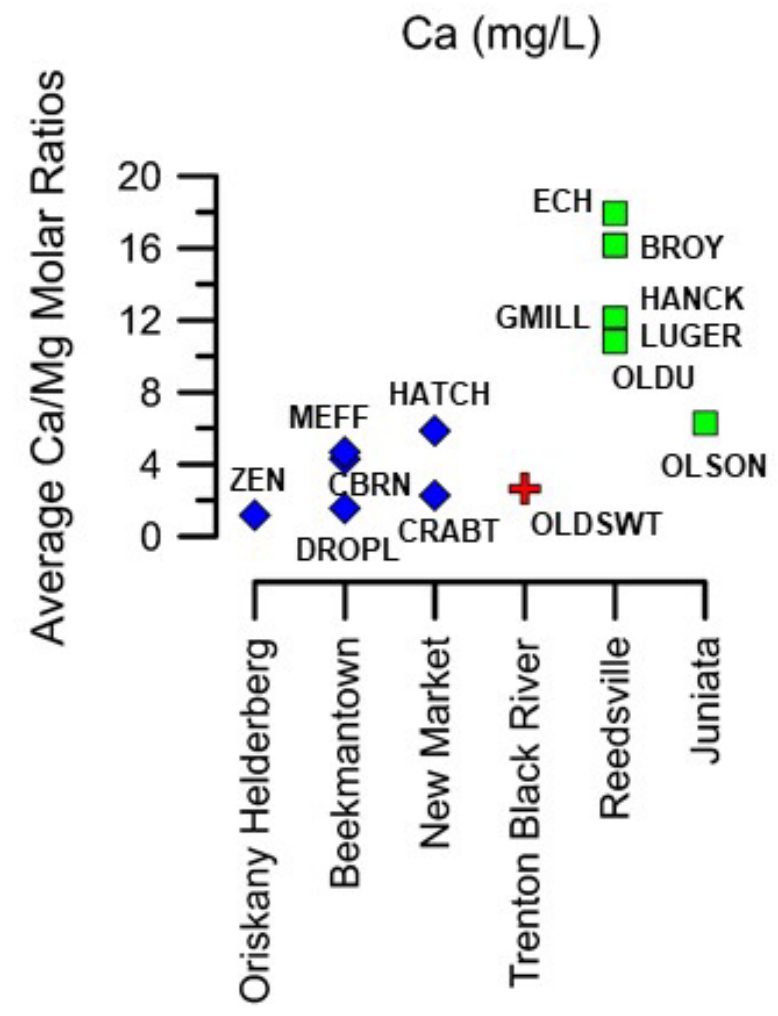

Figure 12: a) $\mathrm{Ca} / \mathrm{Mg}$ molar ratios compared to calcium concentrations for all locations. b) Average Ca/Mg molar ratios for all spring locations separated by formation. Data symbols are spring groups and discharge locations. 
both $\mathrm{Ca}^{2+}$ and $\mathrm{Mg}^{2+}$. Discharge locations tend to have $\mathrm{Ca} / \mathrm{Mg}$ ratios more closely resembling limestone spring ratios.

Clastic springs have the most variable $\mathrm{Ca} / \mathrm{Mg}$ ratios of all locations ( $\sim 50)$. LUGER, GMILL and ECH outcrop in the Reedsville Formation at similar elevations and are located within $6 \mathrm{~km}$ of each other; however, they have notably different average $\mathrm{Ca} / \mathrm{Mg}$ ratios (10.9, 11.1, and 17.9, respectively) (Figure 12). The variability in these ratios is likely due to mixed input from aggregated lithologic sources, various spring-shed sizes, and geologic heterogeneity within the contributing formations.

Spring group has a large effect on the range of alkalinities, while discharge locations have similar alkalinities throughout the study area (Table 5). On average, clastic springs have a low range of alkalinities and carbonate springs have a slightly larger range of alkalinities (Figure 13). The highest alkalinity carbonate spring is ZEN, confirmed by $\mathrm{Ca} / \mathrm{Mg}$ ratios to flow from dolomite. The lowest alkalinities tend to be from the high elevation clastic springs in the Juniata and Reedsville Formations (Figure 13). OLDSWT has the highest alkalinity of all springs due to elevated concentrations of $\mathrm{Ca}^{2+}$ and $\mathrm{Mg}^{2+}$, but tends to be variable. Discharge locations are a composite of spring and runoff waters, as seen in their chemical signatures, and thus are less effected by local differences in geology. However, the greatest variability is seen within discharge locations.

On average, the springs in the study area are undersaturated with respect to $\mathrm{SI}_{\text {calcite, }}$ SI $I_{\text {dolomite }}$ and $\mathrm{SI}_{\text {gypsum; }}$; discharge locations are oversaturated with respect to SI $\mathrm{I}_{\text {calcite }}$ and undersaturated with respect to SI $I_{\text {dolomite }}$ and SIgypsum (Table 6). Clastic springs have lower


average SI $I_{\text {calcite }}$ values, except QSWT and QHAN.

$\mathrm{SI}_{\text {calcite }}$ and $\mathrm{P}_{\mathrm{CO} 2}$ were calculated using PHREEQC software. The relationship between these two parameters gives insight on which locations should precipitate calcite based on kinetic dissolution and precipitation barriers identified by White (1993) (Figure 14). The trend in the overall dataset approximates a degassing line: springs tend to have higher $\mathrm{CO}_{2}$ and lower $\mathrm{SI}_{\text {calcite }}$ values than the surface waters suggesting that the ground water degasses $\mathrm{CO}_{2}$ once it emerges at a spring. (Figure 14). 
Table 5: Alkalinity Statistics

\begin{tabular}{|c|c|c|c|}
\hline Location & $\begin{array}{c}\text { Number of } \\
\text { Samples }\end{array}$ & $\begin{array}{r}\text { Average } \\
\text { Alkalinity } \\
\text { (meq/L) }\end{array}$ & $\begin{array}{l}\text { Standard } \\
\text { Deviation }\end{array}$ \\
\hline \multicolumn{4}{|l|}{ Clastic } \\
\hline HANCK & 3 & 2.06 & 0.104 \\
\hline $\mathrm{ECH}$ & 3 & 1.41 & 0.137 \\
\hline BROY & 3 & 2.49 & 0.167 \\
\hline OLSON & 8 & 1.00 & 0.345 \\
\hline GMILL & 9 & 1.16 & 0.182 \\
\hline OLDU & 3 & 2.42 & 0.285 \\
\hline LUGER & 3 & 0.993 & 0.163 \\
\hline \multicolumn{4}{|l|}{ Carbonate } \\
\hline НАТСН & 3 & 2.22 & 0.529 \\
\hline CBRN & 3 & 2.37 & 0.717 \\
\hline CRABT & 8 & 3.07 & 0.602 \\
\hline DROPL & 3 & 2.33 & 0.418 \\
\hline ZEN & 9 & 4.58 & 0.341 \\
\hline MEFF & 3 & 2.18 & 0.481 \\
\hline \multicolumn{4}{|l|}{ Thermal } \\
\hline OLDSWT & 10 & 11.7 & 1.17 \\
\hline \multicolumn{4}{|l|}{ Discharge } \\
\hline QHAN & 9 & 2.51 & 1.150 \\
\hline QIND & 9 & 2.53 & 1.43 \\
\hline $\mathrm{QRCH}$ & 9 & 2.20 & 0.746 \\
\hline QSEC & 9 & 2.19 & 0.512 \\
\hline QSWT & 9 & 3.39 & 1.25 \\
\hline
\end{tabular}




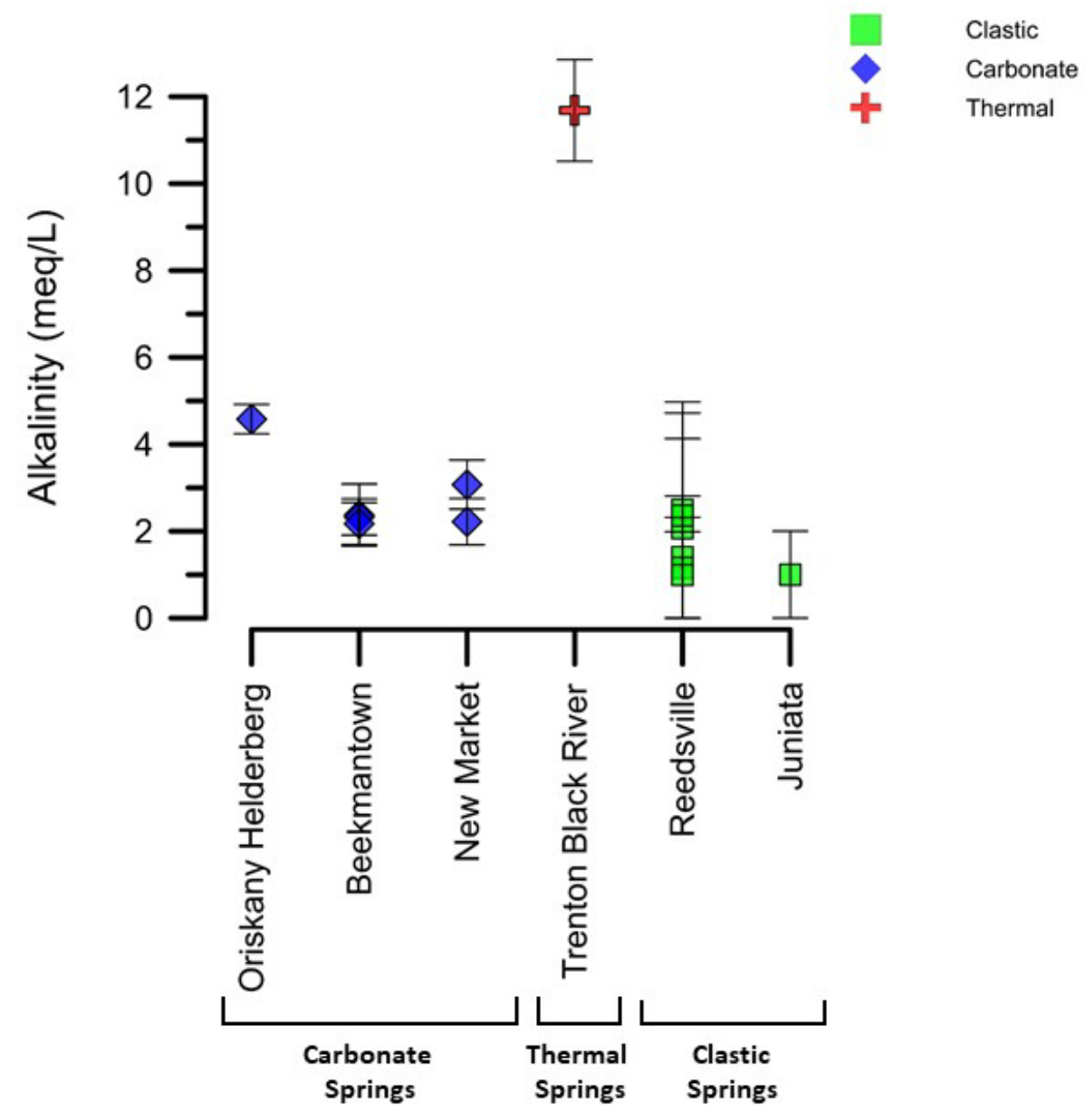

Figure 13: Average spring alkalinities grouped by formation and spring grouping. Error bars are standard deviations and data symbols correspond to spring groups. 
Table 6: Saturation Indices Summary Table

\begin{tabular}{|c|c|c|c|}
\hline Location & $\begin{array}{l}\text { Average } \\
\text { SI }_{\text {calcite }}\end{array}$ & $\begin{array}{l}\text { Average } \\
\text { SIdolomite }\end{array}$ & $\begin{array}{l}\text { Average } \\
\text { SIgypsum }\end{array}$ \\
\hline \multicolumn{4}{|l|}{ Clastic } \\
\hline HANCK & -0.578 & -2.33 & -2.80 \\
\hline $\mathrm{ECH}$ & -0.539 & -2.30 & -3.15 \\
\hline BROY & -0.497 & -2.29 & -2.66 \\
\hline OLSON & -1.47 & -3.83 & -3.04 \\
\hline GMILL & -1.06 & -3.28 & -3.13 \\
\hline OLDU & -0.515 & -2.30 & -2.95 \\
\hline LUGER & -0.845 & -2.84 & -3.09 \\
\hline \multicolumn{4}{|l|}{ Carbonate } \\
\hline НАТСН & -0.635 & -2.12 & -2.86 \\
\hline CBRN & -0.336 & -1.36 & -2.86 \\
\hline CRABT & -0.932 & -2.30 & -2.84 \\
\hline DROPL & -0.522 & -1.33 & -3.06 \\
\hline ZEN & -0.321 & -0.788 & -2.80 \\
\hline MEFF & -0.452 & -1.67 & -2.99 \\
\hline \multicolumn{4}{|l|}{ Thermal } \\
\hline OLDSWT & -0.078 & -0.604 & -0.739 \\
\hline \multicolumn{4}{|l|}{ Discharge } \\
\hline QHAN & -0.092 & -0.681 & -2.79 \\
\hline QIND & 0.101 & -0.370 & -2.94 \\
\hline QRCH & 0.235 & -0.102 & -2.72 \\
\hline QSEC & 0.083 & -0.407 & -3.07 \\
\hline QSWT & -0.443 & -1.44 & -2.54 \\
\hline
\end{tabular}

Samples with charge balances $\pm 10 \%$ were not included 


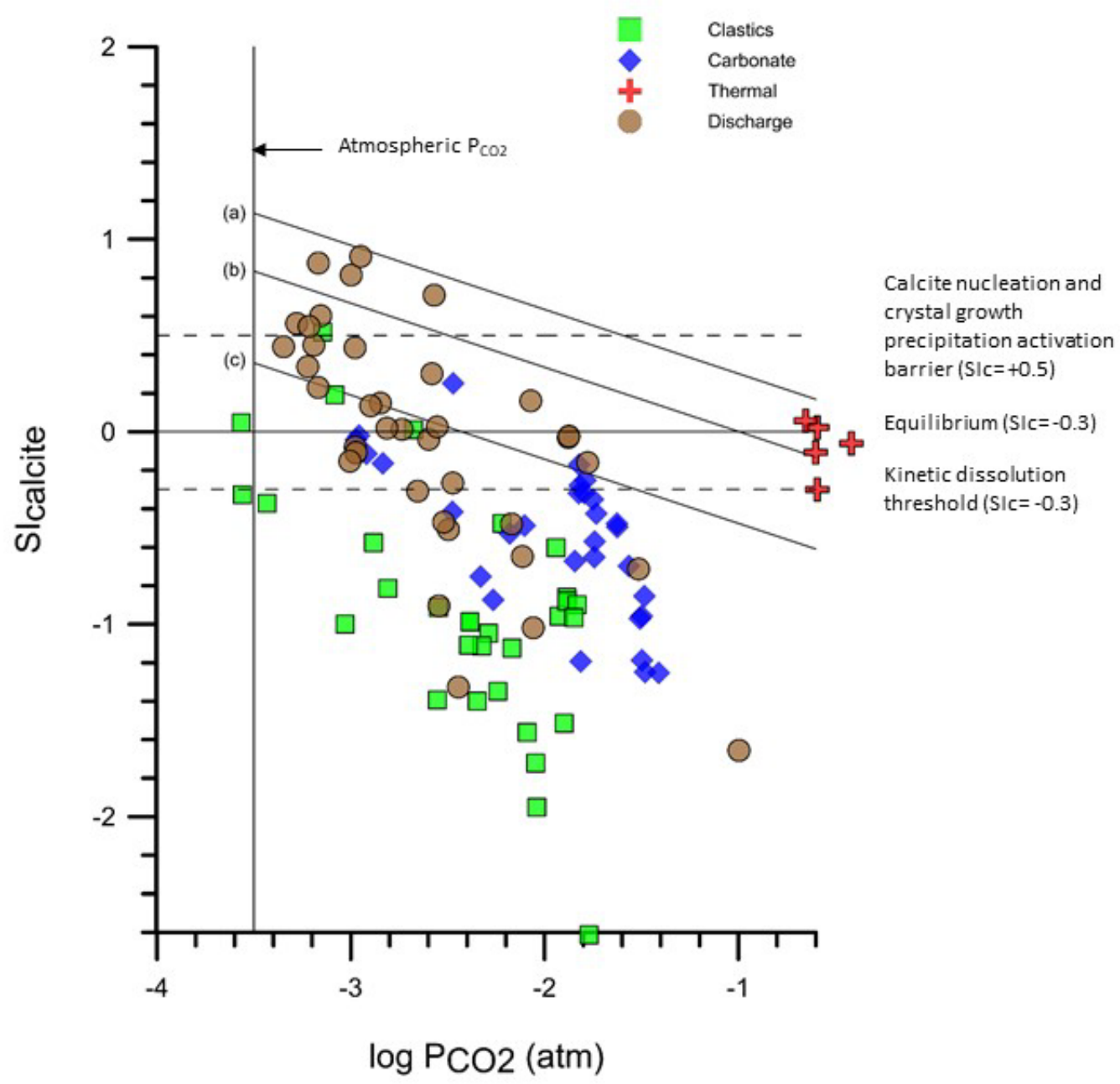

Figure 14: Plot of SIcalcite vs. the partial pressure of $\mathrm{CO}_{2}\left(\mathrm{PCO}_{\mathrm{CO}}\right)$ in collected samples calculated using PHREEQC modeling software. Data symbols correspond to spring groups and discharge locations. Calcite equilibrium is marked by the solid horizontal line and $P_{\mathrm{CO}}$ in equilibrium with the atmosphere is marked with the solid vertical line. The dashed lines represent calcite precipitation and dissolution barriers. Solid diagonal lines (a), (b) and (c) represent theoretical degassing at $\mathrm{Ca}^{2+}$ activities of $6 \times 10^{-3}, 3 \times 10^{-3}$ and $1 \times 10^{-3}$, respectively (White, 1997). OLSON shows an anomalously low SI calcite value on 4/29/2017. 


\subsection{Correlation Matrix}

Linear correlations were completed for carbonate and clastic springs (Table 7) and for the thermal spring using Minitab18 software (Table 8). Cell contents include a Pearson correlation value. Shaded cells indicate correlations with p-values less than 0.01 ; shaded and boxed cells indicate correlations with p-values less than or equal to 0.001. Two water signatures are likely to exist based on the correlation matrix for clastic and carbonate springs and spring chemistry: (1) an alkalinity-SC-Ca-Mg-K-Sr signature, and (2) a Li-Na-NO $3-\mathrm{SO}_{4}$ signature. The first signature is explained by carbonate geochemistry and the second is may indicate deeper thermally related flow. The second signature is also seen in the correlation matrix for solely the thermal spring (Table 8) and confirmed by elevated concentrations of $\mathrm{Li}, \mathrm{Na}$, and $\mathrm{SO}_{4}$ at the thermal spring. $\mathrm{NO}_{3}$ concentrations are lower in the thermal spring and have a more significant correlation with Li compared to carbonate and clastic springs.

\subsection{Temperature Responses}

Cosine curve fitting was done to extract a yearly seasonal temperature response of each spring to provide insight into source-to-spring transmission. Cosine curve fitting was completed in Grapher software using the following adapted equation (Kurz et al., 2013; Riddell, 2015):

$$
C_{t}=M+A \cos \left(\left(\frac{t * 360^{\circ} * \pi}{180^{\circ}}\right)-\left(\frac{H * \pi}{180^{\circ}}\right)\right)
$$

Where M is the mean temperature, A is amplitude of the cosine model, B is period of the model, $\mathrm{H}$ is the phase of the model, and $\mathrm{t}$ is elapsed time. Elapsed time was adjusted before fitting the model to represent annual cycling (365 days) starting on January $1^{\text {st }} 2015$. The adjusted cosine fit curve models seasonal spring responses rather than diel cycles as previously used (Kurz et al., 2013; Riddell, 2015).

The spring cosine models were compared to a daily air temperature model based on data from the National Atmospheric Depositional Program (NADP) online metadata from Babcock State Park in Fayetteville, WV (NADP WV04 2018, Figure 15). Air temperature is used as a proxy for recharge temperature. NADP WV04 station is the closest NADP weather station to Peters Mountain and is located approximately $65 \mathrm{~km}$ away from the spring and discharge locations. Short time scale rainfall amount and rainfall temperature fluctuations at NADP WV04 may not be identical to values at the springs due to the distance from sampling locations, however, seasonal patterns are expected to be relatively consistent. 
Table 7: Correlation Matrix for Carbonate and Clastic Springs

\begin{tabular}{|c|c|c|c|c|c|c|c|c|c|c|c|c|c|c|c|}
\hline Parameter & $\begin{array}{r}\text { Temp. } \\
\text { (C) }\end{array}$ & pH & $\begin{array}{r}\mathrm{SC} \\
(\mathrm{mS} / \mathrm{cm})\end{array}$ & $\begin{array}{r}\text { Raw } \\
\text { Alk. } \\
\text { (meq/L) }\end{array}$ & $\begin{array}{r}\mathrm{Ca} \\
(\mathrm{mg} / \mathrm{L})\end{array}$ & $\begin{array}{r}K \\
(\mathrm{mg} / \mathrm{L})\end{array}$ & $\begin{array}{r}\mathbf{L i} \\
(\mathrm{mg} / \mathrm{L})\end{array}$ & $\begin{array}{r}\mathrm{Mg} \\
(\mathrm{mg} / \mathrm{L})\end{array}$ & $\begin{array}{r}\text { Mn } \\
(\mathrm{mg} / \mathrm{L})\end{array}$ & $\begin{array}{r}\mathrm{Na} \\
(\mathrm{mg} / \mathrm{L})\end{array}$ & $\begin{array}{r}\mathrm{Si} \\
(\mathrm{mg} / \mathrm{L})\end{array}$ & $\begin{array}{r}\mathrm{Sr} \\
(\mathrm{mg} / \mathrm{L})\end{array}$ & $\begin{array}{r}\mathrm{Zn} \\
(\mathrm{mg} / \mathrm{L})\end{array}$ & $\begin{array}{r}\mathrm{Cl} \\
(\mathrm{mg} / \mathrm{L})\end{array}$ & $\begin{array}{r}\mathrm{NO}_{3} \\
(\mathrm{mg} / \mathrm{L})\end{array}$ \\
\hline $\mathrm{pH}$ & -0.188 & & & & & & & & & & & & & & \\
\hline $\mathrm{SC}(\mathrm{mS} / \mathrm{cm})$ & 0.526 & -0.138 & & & & & & & & & & & & & \\
\hline $\begin{array}{l}\text { Raw Alk. } \\
\text { (meq/L) }\end{array}$ & 0.564 & -0.102 & 0.865 & & & & & & & & & & & & \\
\hline $\mathrm{Ca}(\mathrm{mg} / \mathrm{L})$ & 0.582 & -0.100 & 0.754 & 0.825 & & & & & & & & & & & \\
\hline $\mathrm{K}(\mathrm{mg} / \mathrm{L})$ & 0.503 & -0.156 & 0.719 & 0.793 & 0.500 & & & & & & & & & & \\
\hline Li (mg/L) & 0.144 & -0.073 & 0.090 & 0.006 & 0.275 & -0.160 & & & & & & & & & \\
\hline $\mathrm{Mg}(\mathrm{mg} / \mathrm{L})$ & 0.439 & -0.127 & 0.844 & 0.918 & 0.615 & 0.865 & -0.095 & & & & & & & & \\
\hline $\mathrm{Na}(\mathrm{mg} / \mathrm{L})$ & -0.030 & -0.267 & -0.062 & -0.117 & 0.016 & -0.245 & 0.443 & -0.207 & -0.142 & & & & & & \\
\hline $\mathrm{Si}(\mathrm{mg} / \mathrm{L})$ & 0.267 & -0.109 & 0.055 & 0.027 & 0.218 & -0.049 & 0.473 & -0.087 & 0.315 & 0.006 & & & & & \\
\hline $\mathrm{Sr}(\mathrm{mg} / \mathrm{L})$ & 0.347 & -0.078 & 0.801 & 0.778 & 0.576 & 0.620 & 0.056 & 0.858 & 0.046 & 0.025 & -0.047 & & & & \\
\hline $\mathrm{Zn}(\mathrm{mg} / \mathrm{L})$ & -0.217 & -0.106 & -0.258 & -0.197 & -0.187 & -0.256 & -0.040 & -0.147 & -0.046 & 0.352 & -0.114 & -0.099 & & & \\
\hline $\mathrm{Cl}(\mathrm{mg} / \mathrm{L})$ & 0.105 & 0.123 & 0.031 & 0.006 & 0.220 & -0.191 & 0.435 & -0.204 & -0.152 & 0.453 & -0.059 & -0.109 & 0.030 & & \\
\hline $\mathrm{NO}_{3}(\mathrm{mg} / \mathrm{L})$ & -0.025 & -0.006 & 0.129 & 0.140 & 0.004 & 0.161 & -0.539 & 0.249 & -0.148 & -0.198 & -0.395 & 0.212 & 0.004 & -0.378 & \\
\hline $\mathrm{SO}_{4}(\mathrm{mg} / \mathrm{L})$ & 0.193 & -0.073 & 0.186 & 0.134 & 0.020 & 0.335 & -0.332 & 0.227 & 0.226 & -0.105 & 0.109 & 0.242 & -0.087 & -0.220 & 0.093 \\
\hline
\end{tabular}

Cells contain Pearson correlation values calculated in Minitab Version 18 for 67 samples at 13 locations.

Shaded cells have $\mathrm{p}<0.01$; shaded and boxed cells have $\mathrm{p} \leq 0.001$.

Temp.= Temperature; SC= Specific Conductance; Alk.= Alkalinity 


\section{Table 8: Correlation Matrix for the Thermal Spring}

\begin{tabular}{|c|c|c|c|c|c|c|c|c|c|c|c|c|c|c|c|}
\hline Parameter & $\begin{array}{r}\text { Temp. } \\
\text { (C) }\end{array}$ & pH & $\begin{array}{r}\mathrm{SC} \\
(\mathrm{mS} / \mathrm{cm})\end{array}$ & $\begin{array}{r}\text { Raw } \\
\text { Alk. } \\
(\mathrm{meq} / \mathrm{L})\end{array}$ & $\begin{array}{r}\text { Ca } \\
(\mathrm{mg} / \mathrm{L})\end{array}$ & $\begin{array}{r}K \\
(\mathrm{mg} / \mathrm{L})\end{array}$ & $\begin{array}{r}\mathbf{L i} \\
(\mathrm{mg} / \mathrm{L})\end{array}$ & $\begin{array}{r}\mathrm{Mg} \\
(\mathrm{mg} / \mathrm{L})\end{array}$ & $\begin{array}{r}\text { Mn } \\
(\mathrm{mg} / \mathrm{L})\end{array}$ & $\begin{array}{r}\mathrm{Na} \\
(\mathrm{mg} / \mathrm{L})\end{array}$ & $\begin{array}{r}\mathrm{Si} \\
(\mathrm{mg} / \mathrm{L})\end{array}$ & $\begin{array}{r}\mathrm{Sr} \\
(\mathrm{mg} / \mathrm{L})\end{array}$ & $\begin{array}{r}\mathrm{Zn} \\
(\mathrm{mg} / \mathrm{L})\end{array}$ & $\begin{array}{r}\mathrm{Cl} \\
(\mathrm{mg} / \mathrm{L})\end{array}$ & $\begin{array}{r}\mathrm{NO}_{3} \\
\text { (mg/L) }\end{array}$ \\
\hline $\mathrm{pH}$ & -0.358 & & & & & & & & & & & & & & \\
\hline $\mathrm{SC}(\mathrm{mS} / \mathrm{cm})$ & 0.484 & -0.209 & & & & & & & & & & & & & \\
\hline $\begin{array}{l}\text { Raw Alk. } \\
\text { (meq/L) }\end{array}$ & 0.927 & 0.156 & 0.339 & & & & & & & & & & & & \\
\hline $\mathrm{Ca}(\mathrm{mg} / \mathrm{L})$ & 0.061 & 0.327 & 0.180 & 0.305 & & & & & & & & & & & \\
\hline $\mathrm{K}(\mathrm{mg} / \mathrm{L})$ & 0.546 & 0.144 & 0.701 & 0.533 & -0.018 & & & & & & & & & & \\
\hline Li (mg/L) & -0.199 & 0.895 & -0.111 & 0.559 & 0.092 & 0.401 & & & & & & & & & \\
\hline $\mathrm{Mg}(\mathrm{mg} / \mathrm{L})$ & 0.566 & 0.257 & 0.726 & 0.653 & 0.118 & 0.926 & 0.364 & & & & & & & & \\
\hline Mn (mg/L) & 0.383 & 0.423 & -0.098 & 0.463 & -0.021 & 0.459 & 0.557 & 0.191 & & & & & & & \\
\hline $\mathrm{Na}(\mathrm{mg} / \mathrm{L})$ & 0.207 & 0.230 & 0.753 & 0.359 & 0.193 & 0.830 & 0.375 & 0.873 & 0.005 & & & & & & \\
\hline Si (mg/L) & 0.323 & 0.661 & 0.253 & 0.666 & -0.030 & 0.788 & 0.807 & 0.768 & 0.646 & 0.579 & & & & & \\
\hline $\mathrm{Sr}(\mathrm{mg} / \mathrm{L})$ & 0.246 & -0.080 & 0.141 & 0.109 & -0.851 & 0.508 & 0.204 & 0.398 & 0.361 & 0.231 & 0.504 & & & & \\
\hline $\mathrm{Zn}(\mathrm{mg} / \mathrm{L})$ & 0.317 & -0.319 & -0.017 & 0.491 & -0.010 & -0.013 & -0.044 & -0.050 & -0.204 & -0.069 & -0.087 & 0.003 & & & \\
\hline $\mathrm{Cl}$ (mg/L) & 0.115 & 0.493 & 0.511 & 0.232 & 0.763 & 0.204 & 0.279 & 0.514 & -0.016 & 0.406 & 0.342 & -0.444 & -0.377 & & \\
\hline $\mathrm{NO}_{3}(\mathrm{mg} / \mathrm{L})$ & -0.344 & 0.875 & -0.152 & 0.128 & 0.352 & 0.124 & 0.927 & 0.113 & 0.420 & 0.170 & 0.577 & -0.122 & 0.081 & 0.338 & \\
\hline $\mathrm{SO}_{4}(\mathrm{mg} / \mathrm{L})$ & 0.288 & -0.059 & 0.212 & 0.070 & -0.252 & 0.401 & 0.209 & 0.031 & 0.734 & -0.030 & 0.287 & 0.330 & 0.193 & -0.219 & 0.224 \\
\hline
\end{tabular}

Cells contain Pearson correlation values calculated in Minitab Version 18 for 13 samples at 1 location (OLDSWT).

Shaded cells have $\mathrm{p}<0.01$; shaded and boxed cells have $\mathrm{p} \leq 0.001$.

Temp.= Temperature; SC= Specific Conductance; Alk.= Alkalinity 


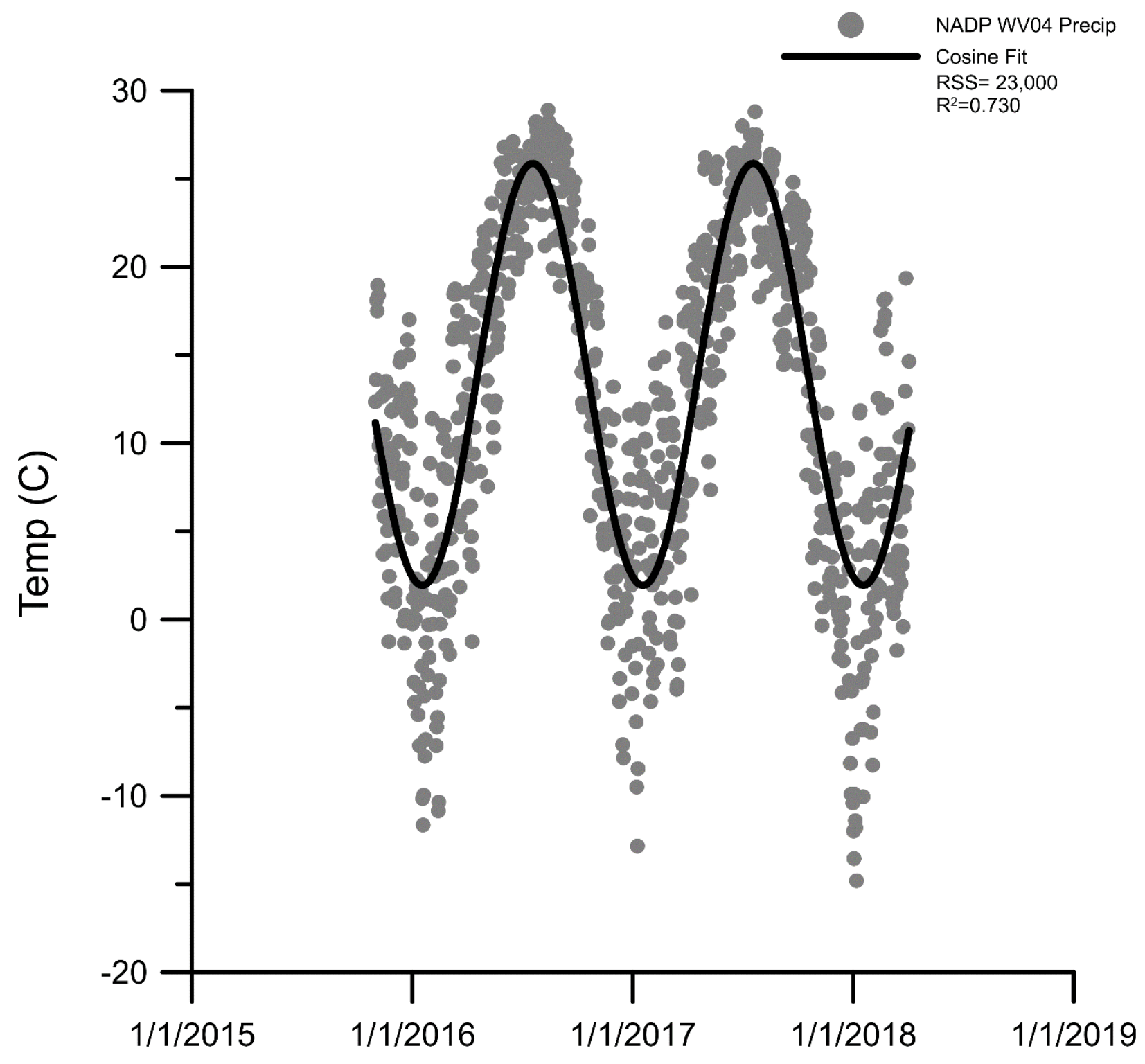

Figure 15: NADP WV04 raw temperature data (gray) and temperature cosine curve fit (black). 
Thermal responses are a combination of seasonal fluctuation and storm event signals; the fit of cosine fit curves determine how well a seasonal trend fits the observed temperatures. The relative sum of squares (RSS) is calculated from the difference between the cosine model and the temperature data, thus can be used as a general evaluation of thermal response not represented by annual patterns (storm responses). RSS in this study was compared between springs as differences in orders-of-magnitude. Springs dominated by event-scale signals and little seasonal fluctuation have high RSS values while springs relatively unaffected by storm events have low RSS values. The highest RSS value seen in this study is in CRABT. Temperature data and cosine models are shown in Figure 16 with corresponding RSS and $\mathrm{R}^{2}$ values. ZEN and LUGER do not have strong seasonal temperature fluctuations and have consistent spring temperatures, confirmed by low temperature relative standard deviations (3.33 and 3.15). LUGER and ZEN springs were not included in the cosine temperature analysis because their temperatures were too constant to obtain a valid model fit.

Cosine curve-fit analysis allowed for the evaluation of seasonal recharge temperature signal propagation based on two quantitative criteria: amplitude dampening factors (ADF) and lag times. Amplitude dampening factors were calculated by the ratio of the NADP fit curve amplitude to the fit curve amplitude at each spring. Greater amplitude dampening factors indicate thermally equilibrated spring temperatures while low amplitude dampening factors are more temperature connected to rainfall events. Lag times are rainfall temperature phase shifts. They are calculated by subtracting the date associated with maximum temperature in the fit curve at each spring to the date associated with maximum temperature in the NADP fit curve. Shorter lag times occur in springs connected to the surface with shorter residence times; conversely, systems with longer residence times will result in longer lag times. These two quantitative measurements give insight on heat transport, type of recharge (dispersed or localized), springshed size, connection to the surface, and overall flow regimes and flow rates as described by Benderitter et al. (1993) and Manga (2001). The individual parameters listed above cannot be determined explicitly; therefore, their combined signature is evaluated by use of the cosine model. Amplitude dampening factors and lag times are reported for each spring (Table 9). Temperature data from MEFF are unavailable due to loss of the data logger in a high flow event. Reinstallation of a new MEFF temperature logger did not provide enough data for cosine fit analysis. 
a)
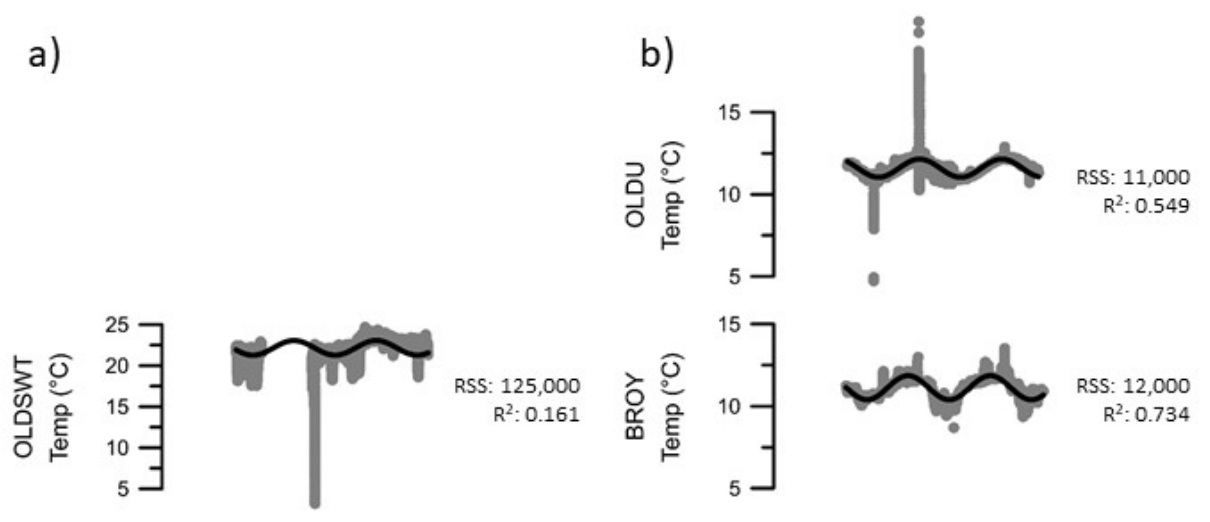

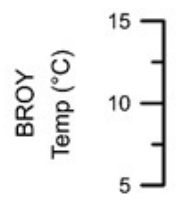

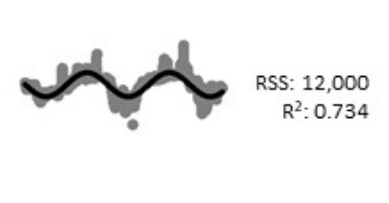

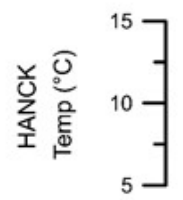



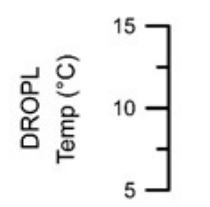







c)
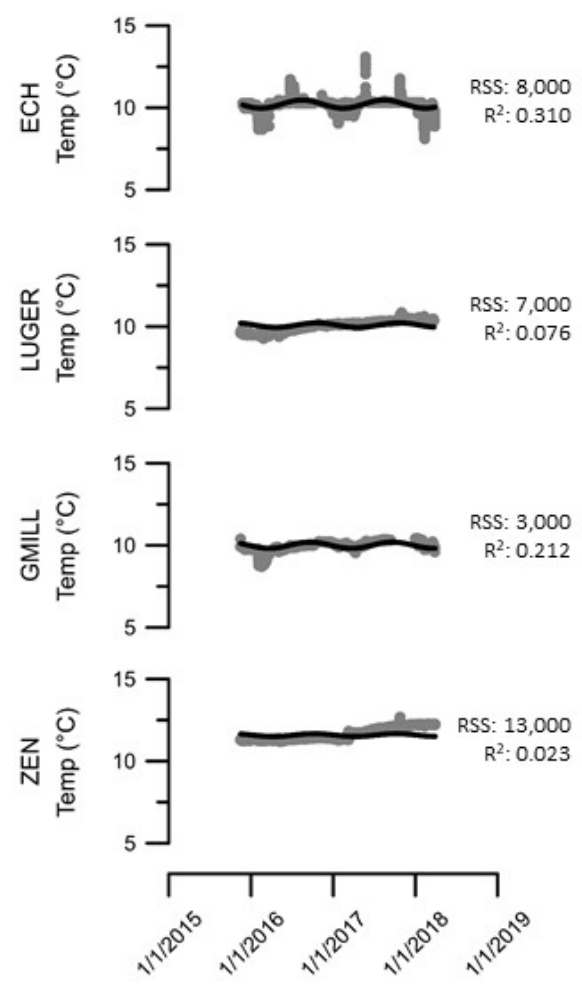

Figure 16: Continuous raw temperature data at all springs are plotted in gray and temperature cosine curve fits are in black. Cosine curve fits were evaluated on a 365 day cycle. Relative sum of squares and $\mathbf{R}^{2}$ values are displayed to evaluate model fit. Data excludes MEFF (data logger lost and when a new logger was reinstalled there were not enough data to evaluate a cosine fit). Plots are organized by amplitude dampening factors: a) springs with amplitude dampening factors less than 15, b) springs with amplitude dampening factors from 16-25, and c) springs with amplitude dampening factors greater than 25. OLDSWT data may not be representative of spring water and may be associated with the spring pool and surface water input. See discussion in text. 
Table 9: Spring Temperature Responses Based on Cosine Fit Models

\begin{tabular}{|c|c|c|c|c|c|c|}
\hline Location & $\begin{array}{r}\text { Max Temp } \\
\left({ }^{\circ} \mathrm{C}\right), \\
\text { Min Temp } \\
\left({ }^{\circ} \mathrm{C}\right)\end{array}$ & $\begin{array}{r}\text { Average } \\
\text { Temp. } \\
\left({ }^{\circ} \mathrm{C}\right)\end{array}$ & $\begin{array}{r}\text { Amp. } \\
\text { Dampening } \\
\text { Factor } \\
\text { (Precip/Spring) }\end{array}$ & $\begin{array}{r}\text { Average Lag } \\
\text { time (Days) }\end{array}$ & $\begin{array}{r}\text { Cosine Fit } \\
\text { Residual } \\
\text { Sum of } \\
\text { Squares } \\
\text { (RSS) }\end{array}$ & ation \\
\hline $\operatorname{PRECIP}^{a}$ & $25.9,1.93$ & 12.4 & 1.0 & 0 & 23,000 & 0.731 \\
\hline \multicolumn{7}{|l|}{ Clastic } \\
\hline HANCK & $11.4,10.1$ & 10.7 & 18 & 6.0 & 30,000 & 0.435 \\
\hline $\mathrm{ECH}$ & $10.5,9.96$ & 10.2 & 48 & 25 & 8,000 & 0.310 \\
\hline BROY & $11.9,10.4$ & 11.0 & 16 & 30 & 12,000 & 0.734 \\
\hline OLSON & $11.5,8.94$ & 10.1 & 9.0 & 33 & 50,000 & 0.642 \\
\hline GMILL & $10.2,9.82$ & 10.0 & 64 & 61 & 3,000 & 0.212 \\
\hline OLDU & $12.1,11.0$ & 11.6 & 22 & 83 & 11,000 & 0.550 \\
\hline \multicolumn{7}{|l|}{ Carbonate } \\
\hline НАТСН & $12.1,10.6$ & 11.3 & 15 & 32 & 5,000 & 0.844 \\
\hline CBRN & $12.2,11.0$ & 11.6 & 19 & 42 & 9,000 & 0.621 \\
\hline CRABT & $15.3,9.21$ & 12.0 & 4.0 & 42 & 108,000 & 0.808 \\
\hline DROPL & $11.4,10.4$ & 10.8 & 23 & 45 & 5,000 & 0.758 \\
\hline \multicolumn{7}{|l|}{ Thermal } \\
\hline OLDSWT & 23.1, 21.1 & 22.0 & 12 & 20 & 125,000 & 0.162 \\
\hline
\end{tabular}

${ }^{a}$ Rainfall data are from NADP NTN site WV 04. LUGER and ZEN not included due to poor model fits

Average lag times are calculated from Season 1 (2016-2017) and Season 2 (2017-2018) cycles

Temp. $=$ Temperature; Amp. $=$ Amplitude

The data from OLDSWT was not included here; the data may not fully reflect the ground water temperature due to the influence of the spring pool and surface water input. 
The springs with the greatest amplitude dampening factors and smallest seasonal temperature response are GMILL and ECH; the springs with the lowest amplitude dampening factors are CRABT, OLSON, OLDSWT, and HATCH (Figure 17). Low amplitude dampening factors tend to be found in carbonate springs, however non-carbonate springs can have low amplitude dampening factors due to type of recharge, spring-shed size, and flow rates and regimes (Benderitter et al., 1993; Manga, 2001). CRABT and HATCH both are dominated by annual temperature cycles, although they do show some event-scale fluctuation. They both emerge in the carbonate valley from the New Market Formation, one in a cave system (HATCH) and one with adjacent sinkholes (CRABT). These systems are likely dominated by point-source recharge which causes them to reflect temperatures similar to rainfall. In general, amplitude dampening factors increase with increasing elevation except for OLSON (Figure 18). All springs with dampening factors above 25 are at high elevation on Peters Mountain; springs with factors less than 15 are of similar lower elevation.

Temperature lag times were calculated for two seasons and averaged (2016-2017 and 2017-2018) (Table 9). The lag times for both seasons agree within 5\% except for HANCK (20.3\%). The average lag time temperature response for all springs is 41 days; lag times for all carbonate and clastic springs are similar ( 40). The springs with the shortest lag times are HANCK and ECH and respond within 15 days of maximum NADP temperature. The springs with the longest lag time are OLDU and GMILL.

The relationship between amplitude dampening factors and lag times were compared for all springs to understand the residence time of each system (Figure 19). The clastic springs have some of the highest amplitude dampening factors of all spring groups, but overall no linear relationship exists as there is a large range of factors and lag time offsets (Figure 19). BROY and OLSON have low amplitude dampening factor-lag time relationships like the carbonate springs. As lag time increases in the carbonate springs, amplitude dampening factors also increase except in CRABT (Figure 19). The carbonate springs have the lowest amplitude dampening factors and lag times around 40 days. The thermal spring has an amplitude dampening factor and lag time offset similar to the carbonate springs. 


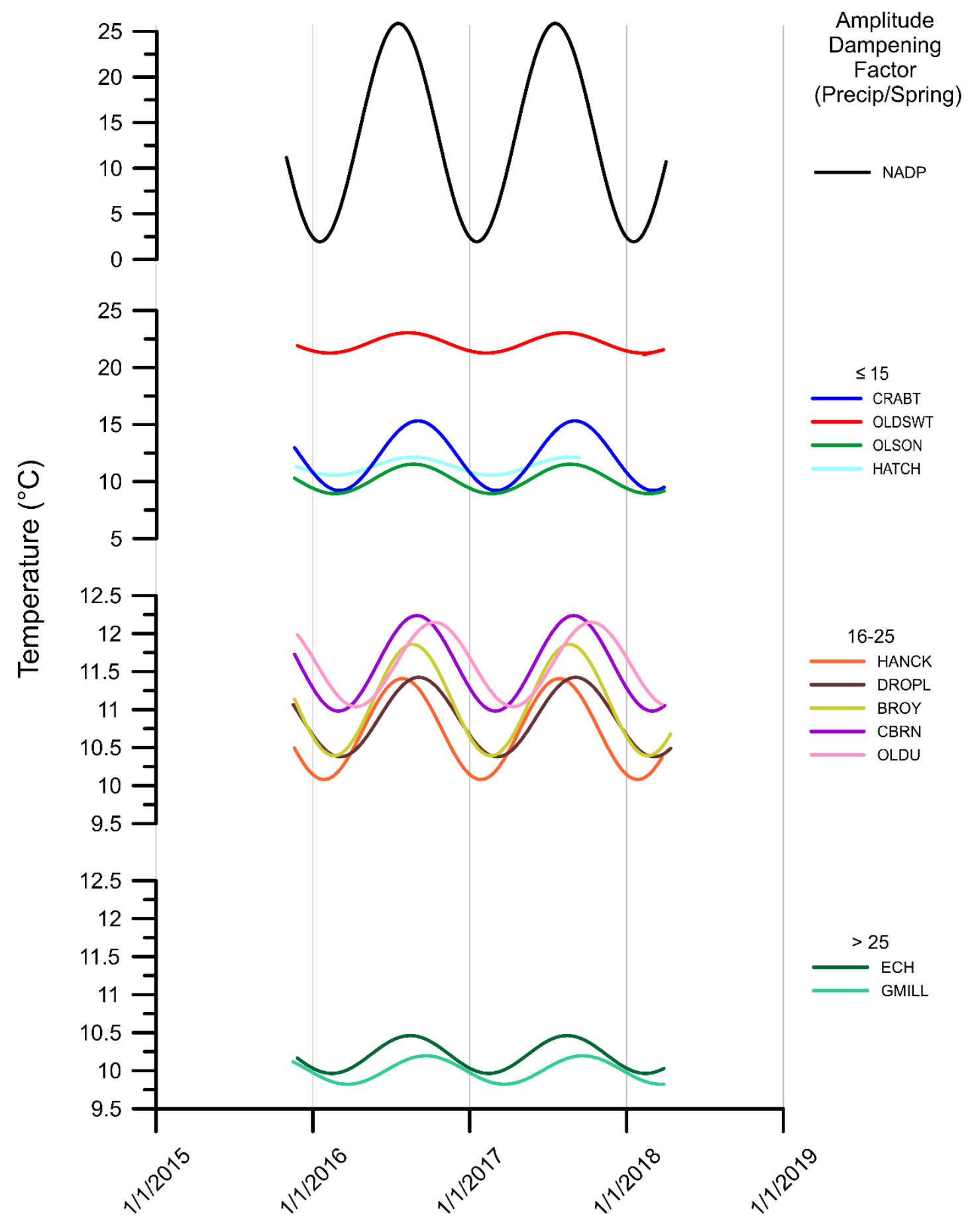

Figure 17: Temperature cosine fit models for all springs separated by amplitude dampening factors. The NADP WV04 cosine fit curve is plotted here at the top of the figure. Note the difference in temperature scale in the springs with higher amplitude dampening factors (16-25 and >25). 


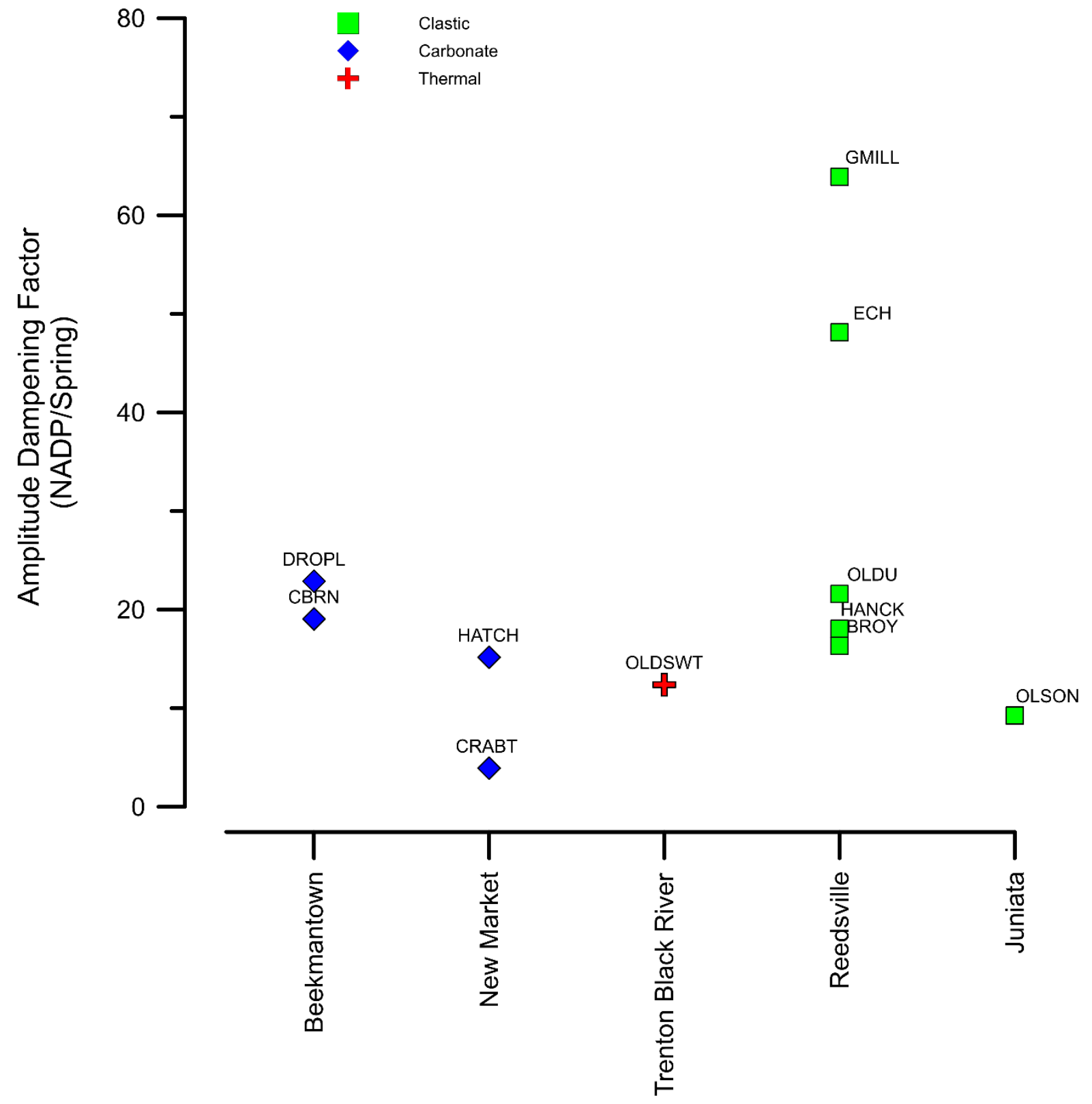

Figure 18: Amplitude dampening factors for all springs grouped by formation. Data symbols correspond to spring groups. OLDSWT data may not be representative of spring water and may be associated with the spring pool and surface water input. See discussion in text. 


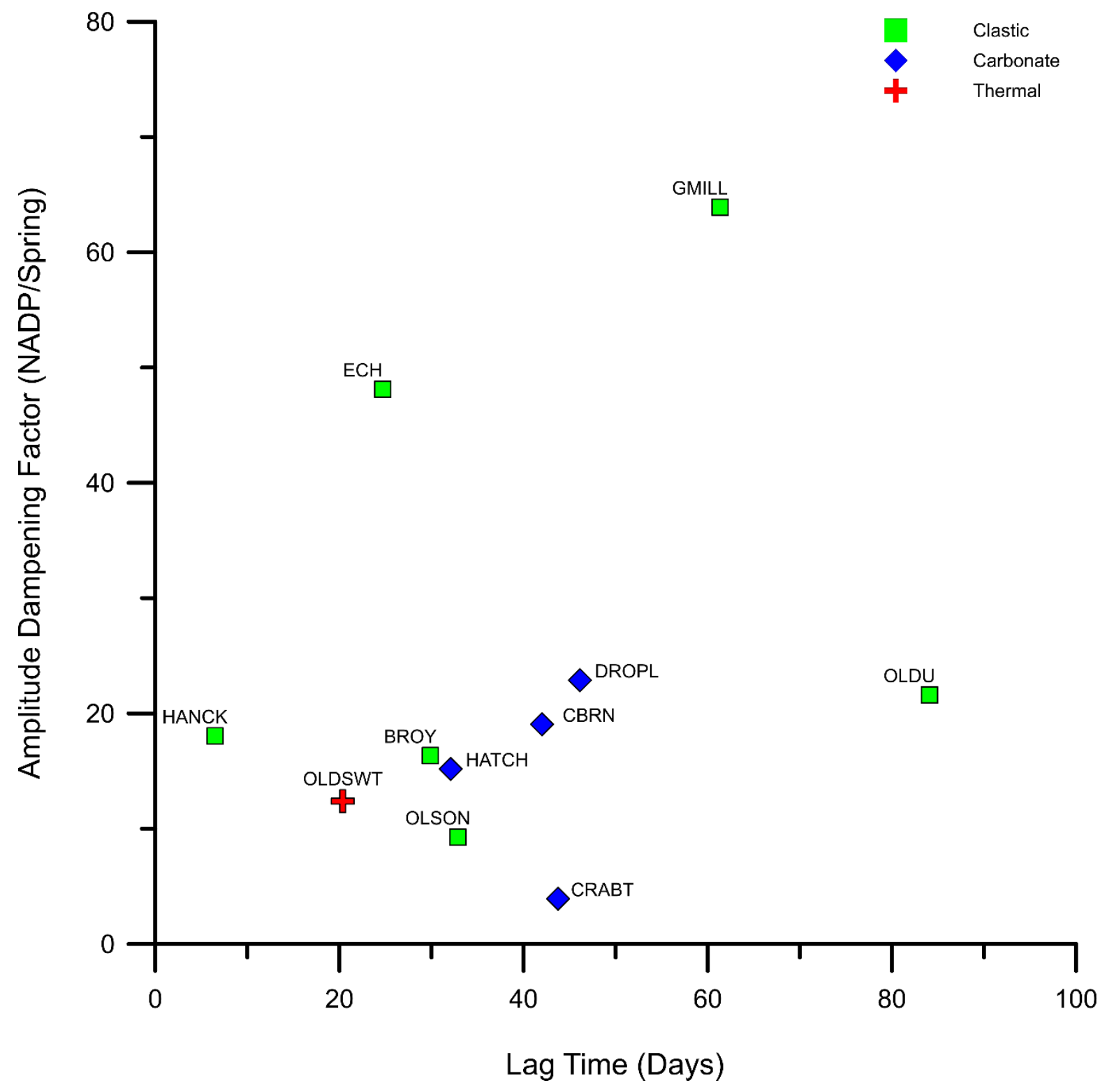

Figure 19: Amplitude dampening factor-lag time relationships for all springs. Data symbols correspond to spring groups; labels are individual spring locations. OLDSWT data may not be representative of spring water and may be associated with the spring pool and surface water input. See discussion in text. 
Temperature responses in ZEN and DROPL are different despite their close proximity and similar $\mathrm{Ca} / \mathrm{Mg}$ ratios. ZEN has a constant temperature that only fluctuates $1.5^{\circ} \mathrm{C}$ throughout the study. DROPL is a cave system with annual temperature cycles and fluctuates $2.6^{\circ} \mathrm{C}$. It is likely that DROPL is controlled by conduit flow and ZEN dominated by fracture and matrix flow.

CBRN and HANCK springs are located within $1 \mathrm{~km}$ and have similar thermal responses. HANCK emerges from the Reedsville Formation and CBRN is further downslope in the Brallier Formation. HANCK has greater magnitude drops in temperature during the winter months than CBRN. This could be due to less interaction time between the water and rock, faster infiltration rates in the winter, or a smaller spring-shed at the higher elevation location.

BROY has a strong seasonal temperature cycle with event-scale fluctuations. BROY's low amplitude dampening factor and more flashy temperature responses is similar to the responses seen in HANCK and could be due to geologic heterogeneity within the Reedsville further south in the county.

\subsection{Indicator Organisms}

Total coliform bacteria and Escherichia coli (E. coli) are used as indicators of contamination and surface input. E. coli is particular to human and warm blooded animal feces, thus is a good indicator of human induced and agricultural pollution (Grabow, 1996). The main sources of these bacteria are found on land surface, therefore they indicate close connections between the surface and the spring. Dilution was necessary in some discharge location and spring samples after extended periods of rain; both indicators are reported as final concentrations in units of counts per $100 \mathrm{~mL}$.

Total coliform bacteria and E. coli were analyzed in springs and discharge locations to evaluate surface connection (Table 10). Counts of E. coli and total coliform bacteria generally increase with greater amounts of weekly rainfall (Figure 20). Discharge locations have elevated counts of total coliform and E. coli bacteria compared to springs. Carbonate springs consistently have the highest counts of $E$. coli bacteria within the spring groups. However, after four or more centimeters of rain per week, all springs have similar counts of $E$. coli bacteria. 
Table 10: Total Coliform and E. coli Results

\section{Total Coliform Counts $/ 100 \mathrm{~mL} \quad$ E. coli Counts $/ 100 \mathrm{~mL}$}

\begin{tabular}{|c|c|c|c|c|c|c|}
\hline Location & $\begin{array}{r}\text { Max } \\
(\mathrm{mg} / \mathrm{L})\end{array}$ & $\begin{array}{r}\operatorname{Min} \\
(\mathrm{mg} / \mathrm{L})\end{array}$ & $\begin{array}{r}\text { Average } \\
(\mathrm{mg} / \mathrm{L})\end{array}$ & $\begin{array}{r}\text { Max } \\
(\mathrm{mg} / \mathrm{L})\end{array}$ & $\begin{array}{r}\text { Min } \\
(\mathrm{mg} / \mathrm{L})\end{array}$ & $\begin{array}{r}\text { Average } \\
\text { (mg/L) }\end{array}$ \\
\hline \multicolumn{7}{|l|}{$\overline{\text { Clastic }}$} \\
\hline HANCK* & 107.1 & 61.3 & 84.2 & 1.0 & $<1.0$ & $<1.0$ \\
\hline $\mathrm{ECH}^{*}$ & 6.3 & 3.1 & 4.7 & $<1.0$ & $<1.0$ & $<1.0$ \\
\hline BROY* & 159.7 & 30.9 & 95.3 & $<1.0$ & $<1.0$ & $<1.0$ \\
\hline OLSON & $>2419.6$ & 26.5 & 217.6 & 25.6 & $<1.0$ & 11.6 \\
\hline GMILL & 727.0 & 4.1 & 123.5 & 11.8 & $<1.0$ & 4.6 \\
\hline OLDU & 155.3 & 8.6 & 58.7 & $<1.0$ & $<1.0$ & $<1.0$ \\
\hline LUGER* & 11.0 & 4.1 & 7.55 & $<1.0$ & $<1.0$ & $<1.0$ \\
\hline \multicolumn{7}{|l|}{ Carbonate } \\
\hline НАТСH & 1011.2 & 166.4 & 588.8 & 19.9 & 14.5 & 17.2 \\
\hline CBRN* & 272.3 & 67.7 & 170.0 & 8.5 & 5.2 & 6.9 \\
\hline CRABT & 1986.3 & 123.6 & 791.8 & 80.1 & $<1.0$ & 37.9 \\
\hline DROPL & 218.7 & 37.9 & 128.3 & 3.1 & 3.0 & 3.0 \\
\hline ZEN & 913.9 & 4.1 & 186.1 & 2.0 & $<1.0$ & 1.5 \\
\hline MEFF* & 209.8 & 37.9 & 123.9 & 3.1 & 2.0 & 2.6 \\
\hline \multicolumn{7}{|l|}{ Discharge } \\
\hline QHAN & $>2419.6$ & 870.4 & 1324.8 & $>2419.6$ & 24.6 & 1140.8 \\
\hline QIND & $>2419.6$ & 870.4 & 1357.9 & 396.8 & 80.4 & 229.0 \\
\hline QRCH & $>2419.6$ & 520.6 & 1399.8 & $>2419.6$ & 85.2 & 720.4 \\
\hline QSEC & $>2419.6$ & 913.9 & 1396.2 & 1098.6 & 129.1 & 616.0 \\
\hline QSWT & 2022.4 & 960.6 & 1474.6 & 1011.2 & 37.4 & 308.4 \\
\hline
\end{tabular}

*Locations contain only one concentration within calibration curve limits Lower limit of IDEXX method is $<1.0$; upper limit is $>2419.6$

OLDSWT data was not included due to influence of the spring pool and surface water input. See discussion in text. 
a)

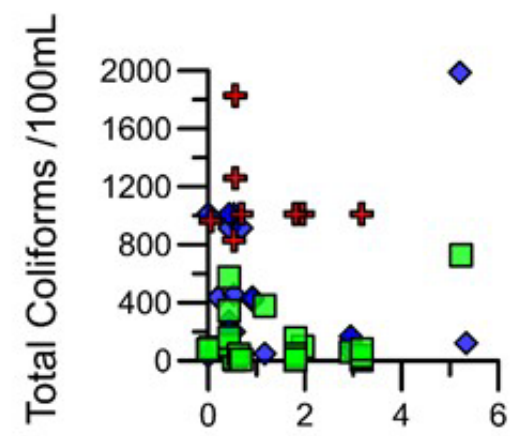

Weekly Precip. (cm) b)

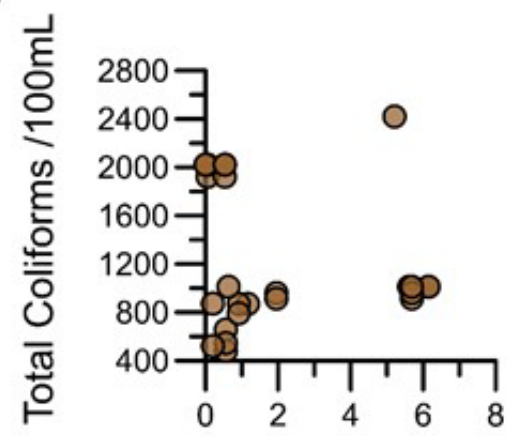

Weekly Precip. (cm)
Carbonate

Clastic a)



Weekly Precip. (cm) b)

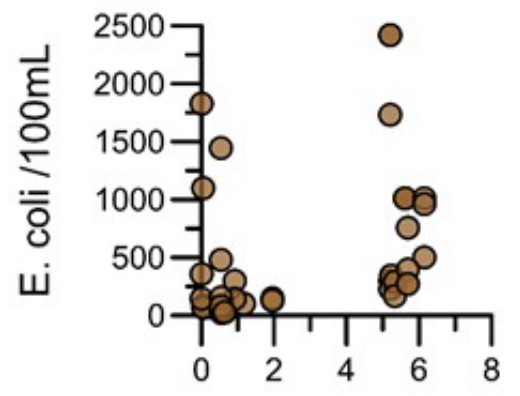

Weekly Precip. (cm)

Figure 20: $E$. coli and total coliform bacterial results for all locations compared to weekly rainfall data. The upper panel displays total coliform counts for a) springs and b) discharge locations. The lower panel displays $E$. coli counts for a) springs and b) discharge locations. Data symbols correspond to spring groups and discharge locations. OLDSWT data may not be representative of spring water and may be associated with the spring pool and surface water input. See discussion in text. 
The total coliform and E. coli data from OLDSWT is unlikely to be representative of the actual ground water conditions because the sample was collected near the edge of the pool and not from the base of the pool. Instead, it likely reflects the combination of spring water temperature, interactions in the spring pool, and possible flow from the hard surfaces surrounding the spring pool. The data has been included in the report for comparison but should only be used for that purpose.

\subsection{NPOC}

Most total organic carbon is in the form of dissolved organic carbon (DOC) by the time it enters the system. DOC was evaluated in the form of NPOC in this study. Allochthonous organic carbon is input into karst systems in two ways: 1) direct input via disappearing streams and sinkholes, and, 2) infiltration through the soil zone In general, NPOC is considered to be an indicator of surface input in karst systems (Charlier et al., 2012). Increased NPOC concentrations are evident in summer months and decreased NPOC concentrations occur in the winter. High discharge events flush this NPOC into karst systems more rapidly, evident in concentration spikes.

On average, the carbonate springs have the highest concentrations of NPOC of the springs, while discharge locations have the highest concentrations overall (

Table 11). Clastic and thermal springs have comparable average NPOC concentrations. CBRN and CRABT have the highest average NPOC concentrations while OLDU has the lowest concentration.

The NPOC data from OLDSWT is unlikely to be representative of the actual ground water conditions because the sample was collected near the edge of the pool and not from the base of the pool. Instead, it likely reflects the combination of spring water temperature, interactions in the spring pool, and possible flow from the hard surfaces surrounding the spring pool. The data has been included in the report for comparison but should only be used for that purpose. 
Table 11: NPOC Shimadzu Data

\begin{tabular}{lrrr} 
Location & $\begin{array}{r}\text { Max } \\
\text { NPOC } \\
\text { (mg/L) }\end{array}$ & $\begin{array}{r}\text { Min } \\
\text { NPOC } \\
(\mathbf{m g} / \mathbf{L})\end{array}$ & $\begin{array}{r}\text { Average } \\
\text { NPOC } \\
\text { (mg/L) }\end{array}$ \\
\hline \hline Clastic & & & \\
HANCK* & 0.761 & 0.761 & 0.761 \\
ECH* & 0.695 & 0.695 & 0.695 \\
BROY* & 0.095 & 0.952 & 0.952 \\
OLSON & 3.76 & 0.324 & 1.44 \\
GMILL & 0.266 & 0.246 & 0.256 \\
OLDU & 0.120 & 0.112 & 0.116 \\
LUGER* & 0.775 & 0.775 & 0.775 \\
Carbonate & & & \\
HATCH & & & \\
CBRN* & 0.891 & 0.523 & 0.707 \\
CRABT & 1.23 & 1.23 & 1.23 \\
DROPL & 2.94 & 0.633 & 1.47 \\
ZEN & 0.829 & 0.586 & 0.707 \\
MEFF* & 0.962 & 0.247 & 0.566 \\
Discharge & 0.852 & 0.852 & 0.852 \\
QHAN & & & \\
QIND & & & \\
QRCH & 5.92 & 2.48 & 3.97 \\
QSEC & 4.14 & 0.861 & 1.82 \\
QSWT & 33.3 & 0.850 & 5.72 \\
\hline \hline
\end{tabular}

*Locations contain only one concentration within calibration curve limits OLDSWT data was not included due to influence of surface input and the spring pool. See discussion in text. 


\subsection{Discharge}

Due to the density of springs on Peters Mountain and the difficulty of gathering discharge measurements, total discharge associated with Peters Mountain was estimated by composite discharge at five locations in the study area. Discharge was measured at all locations from October 2016-August 2017 (Figure 21). Duplicate discharge measurements were completed at each location on most sampling trips (except during high flow) and relative standard deviations were $<3 \%$. Measured peak total discharge occurs in April and individual location contribution is relatively consistent throughout the year. QIND and QRCH are the greatest contributors to total discharge; QHAN consistently has the contribution. Discharge measurements collected do not reflect the full range of discharges apparent at each location; low flows are difficult to measure and high flows are unsafe to collect using this technique.

Stage was measured relative to the stream profile in QRCH, QSWT, QSEC, and QHAN. QIND was unable to be adjusted to the stream profile; a tree root system was present where the staff gage was installed, yielding a depth deeper than the maximum depth of the stream profile due to undercutting. Additional stage adjustments were necessary to account for vertical offsets seen when loggers were downloaded and when well points were displaced due to high flow. Not enough data were gathered regarding the re-deployment of the pressure transducers within the well points to ensure that placement was consistent throughout the study. Data adjustment was completed manually to best match measured adjusted stages and baseflow conditions. Manually measured discharge is independent of continuous data logger stage, and associated error, and was also used to validate data adjustments. Additionally, a USGS gage located on Indian Creek in Red Sulphur Springs, WV (ID 03177480) was used for comparison in adjustments, especially at QIND.

Rating curves were compiled for each location (Figure 22). Both power and linear curves were used to fit the stage-discharge relationships. QRCH, QSWT, and QSEC have linear stage-discharge relationships while QHAN and QIND stage-discharge relationships are described by power functions. The best fits were found at QSEC and QHAN; the worst at QSWT. 




Figure 21: Measured combined total discharge is plotted on the top y-axis. The bottom $y$-axis shows percentage of contributions to the total discharge from all five locations. Creek labels correspond to the adjacent colors and percentages. Data were collected from October 2016 to August 2017. 
a)
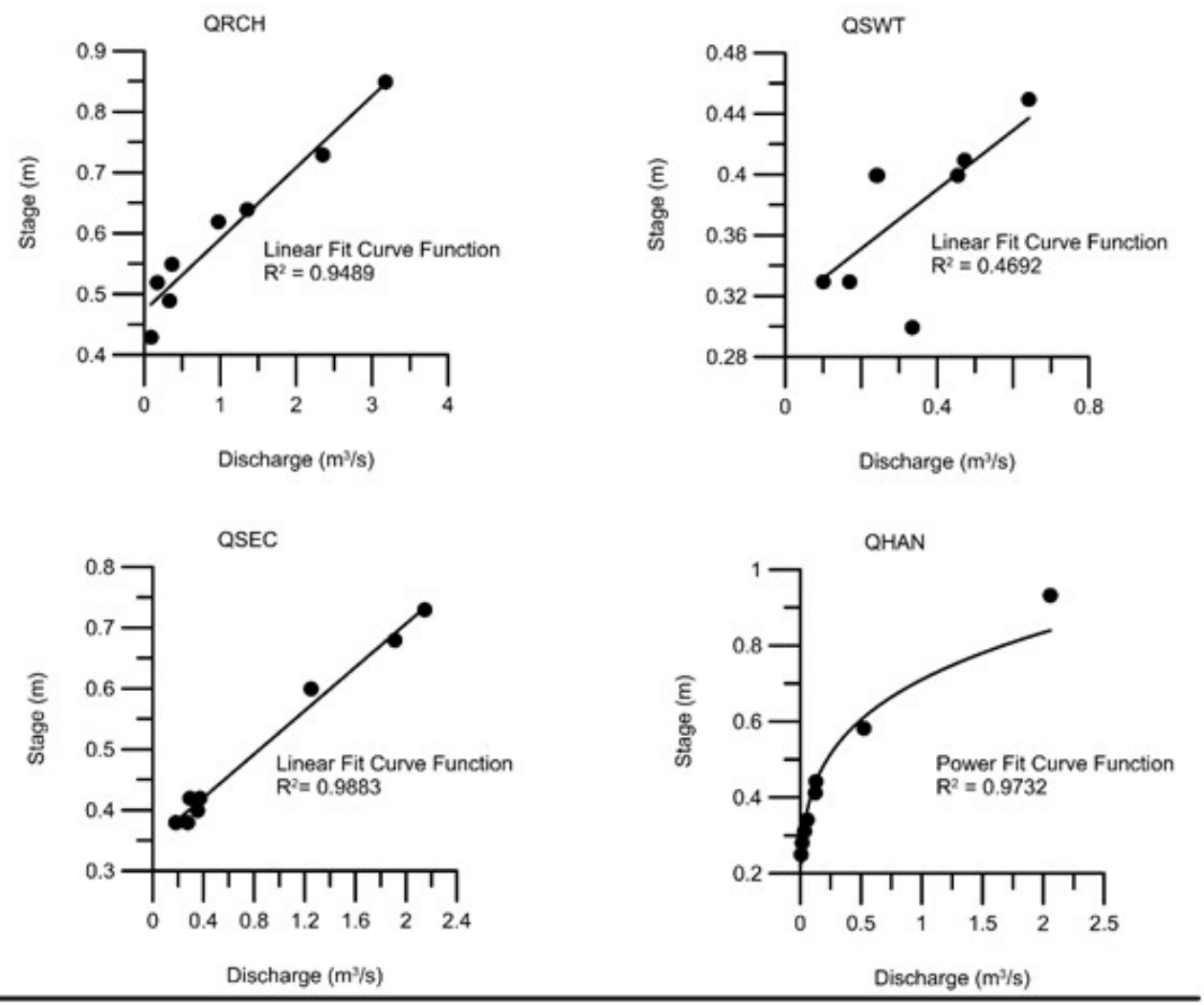

b)

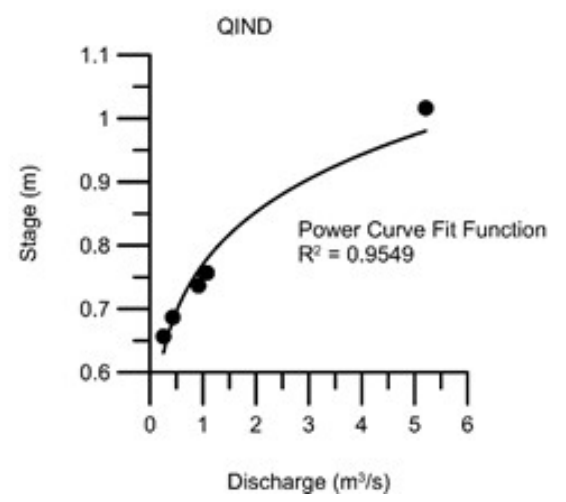

Figure 22: Continuous stage-discharge rating curves for all five discharge locations. a) Stage-discharge relationships include stream profile corrections. Relationships are represented by linear and power functions. Note, QHAN only contains four data points after the installation of the well point. b) Stage-discharge relationships without a stream profile correction, represented by a power function. 
Stage is influenced by rainfall events (Figure 23). Due to error associated with logger placement, magnitude changes within are the focus of comparisons between different discharge locations. Early stage dataset tends to be noisy due to the loose attachment of the logger to the staff gage via fishing line. By April $30^{\text {th }}$, 2017 all loggers were placed inside of well points to ensure more consistent placement. However, some well points were dislodged in high flow events because the bedrock stream beds made installation difficult. QSEC and QRCH well points were washed ashore during a major rainfall event reported by land owners and recorded in stage fluctuations on October $23^{\text {rd }}, 2017$.

Stage fluctuations in all discharge locations were evaluated to determine stream responses through time (Figure 23). Stage magnitude comparisons cannot be made between locations due to differences in stream geometry; these comparisons focus on whether storms are seen between discharge locations. Responses to large storm events are evident at all locations and are indicated by stage increases from late April to June and in October. Stage at QHAN is much more variable before well point installation. QHAN is located in the middle of a cow pasture field and is a highly-vegetated bedrock bottom stream topped with unconsolidated material. The stage in this stream is variable and during high flow conditions, erosion may change the stream profile with respect to location and depth and sediment deposition also may occur. QIND exhibits increases in stage with rain events but cannot be compared spatially with other locations (Figure 24). QIND stage in this study exhibits similar stage responses to Indian Creek in Red Sulphur Springs, WV (ID 03177480) (Figure 24).

Although discharge measurements are valley-wide composites of many springs, evaluating chemistry changes compared to discharge provides insight to responses in the surrounding region after rain events. It is expected that as discharge increases, concentrations of major ions associated with carbonate dissolution would decrease. Negative Pearson correlation values are seen in $\mathrm{Ca}^{2+}$ and $\mathrm{Mg}^{2+}$ within individual discharge locations and range from -0.453 to -0.873; however, these correlations are not significant and have p-values greater than 0.01. Error in these correlations is potentially linked to an insufficient amount of high flow data gathered at discharge locations. 
a)

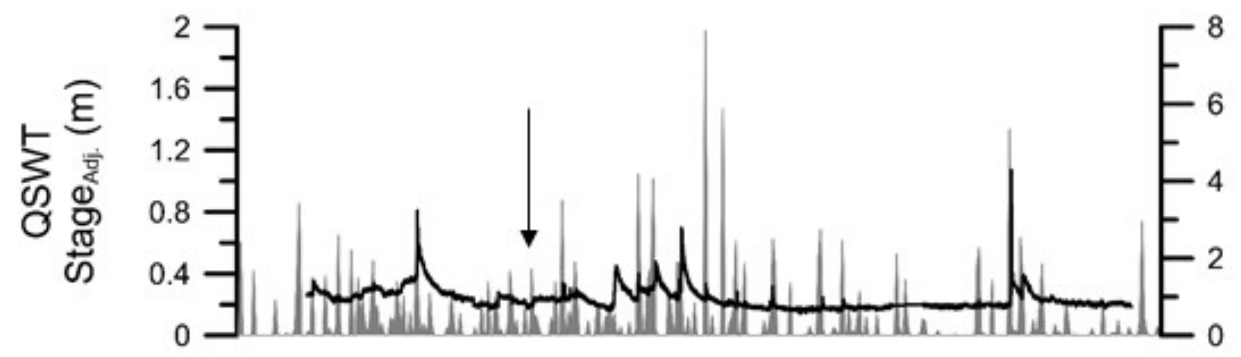

b)

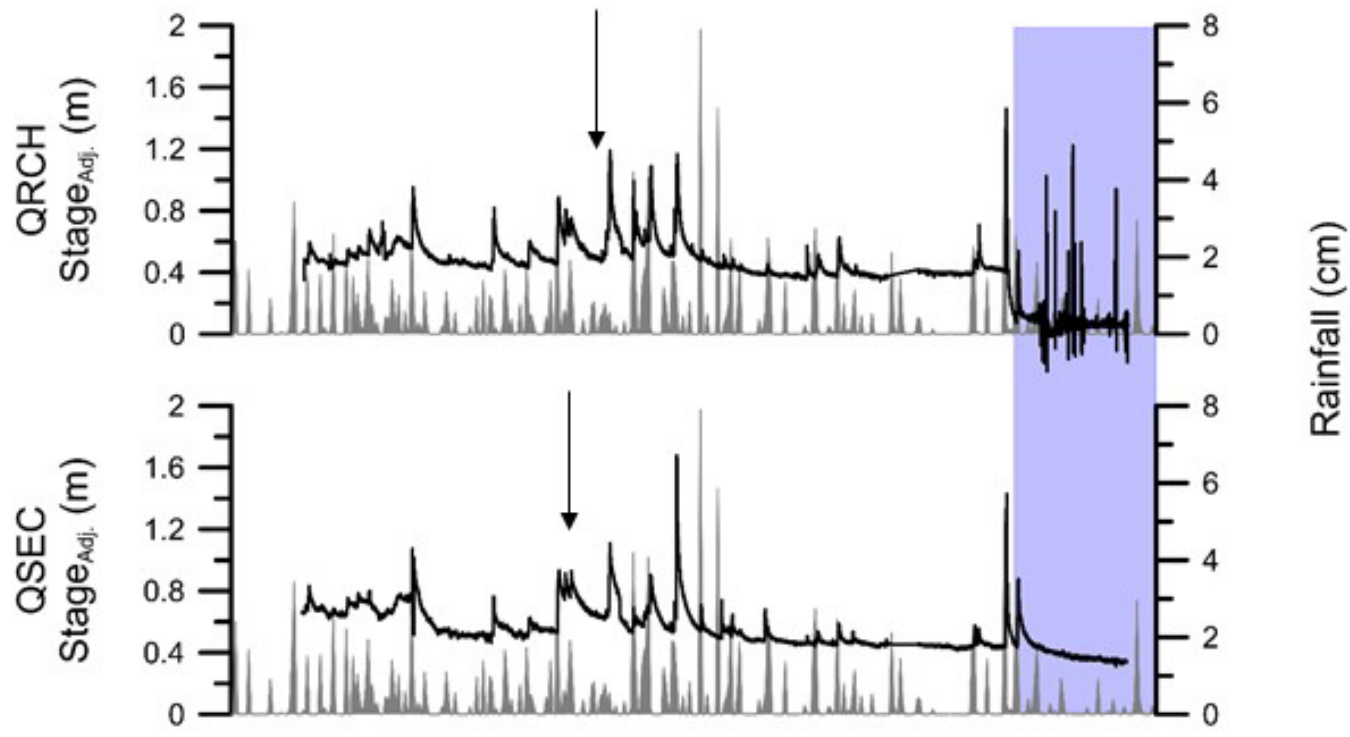

d)


Figure 23: Graphs a)-d) show final adjusted stage at QSWT, QRCH, QSEC, and QHAN through time. Stage is plotted in black on the left y-axis and rainfall is plotted in gray on the right $y$-axis. The barometric control data logger is located at QIND, a discharge location not shown here because adjusted stage could not be calculated. a) QSWT is the furthest discharge location from the barometric pressure logger and b) QHAN is located the closest. Arrows indicate the installation of well points to contain the pressure loggers. The blue shaded region indicates when well points were displaced from the streams due to high flow. 
a)



b)

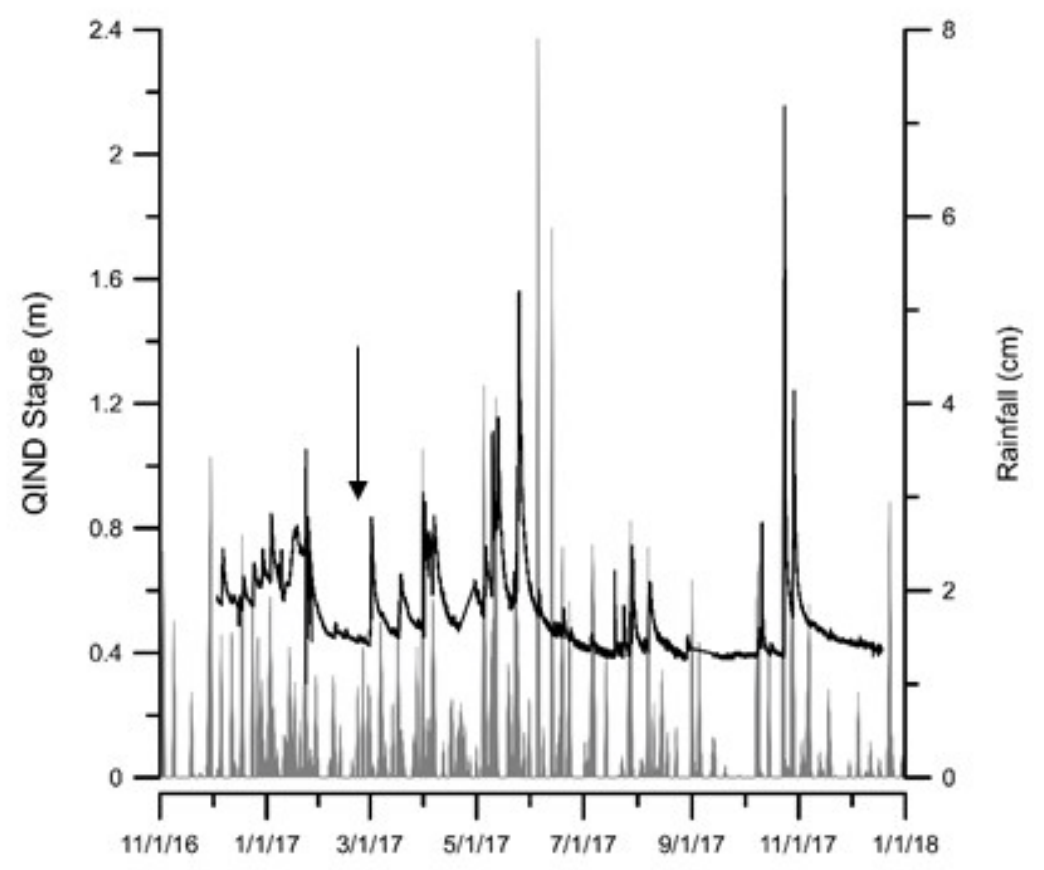

Figure 24: Stage is plotted in black on the left $y$-axis and rainfall is plotted in gray on the right y-axis. a) Stage at USGS Indian Creek gage 03177480 in Red Sulphur Springs, WV through time. b) Stage at QIND in this study through time. Locations are approximately 13 kilometers away. The arrow indicates the installation of well points to contain the pressure loggers. 
Total coliform and E. coli bacteria were evaluated in the indicator springs to assess effects of discharge events on concentrations. Due to the difficulty in establishing a continuous stage-discharge relationship using data loggers in QIND (the largest contributing stream to total flow), total coliform and E. coli counts vs. total discharge were only evaluated for sampling trips where both flow and springs were sampled. It is expected that concentrations of the above parameters would increase with large discharge events, especially in the carbonate springs; however, no significant correlation between discharge and other parameters is evident for individual springs (Figure 25).

No relationships were seen between NPOC and discharge; it is important to note that only one high discharge event was measured (Figure 26). Sampling resolution was not frequent enough to capture storm-induced NPO concentration changes input into the springs.

The combined discharge gives insight to total flow leaving the valley as a composite of all spring discharge. This valley-wide approach to determining flow associated with Peters Mountain is advantageous, but cannot be used to evaluate responses at specific spring locations. This is confirmed by the lack of correlation seen between discharge, total coliform bacteria, $E$. coli bacteria, and NPOC at individual springs and the variety of individual spring response to seasonal fluctuations based on long-term temperature evaluation. 
a)

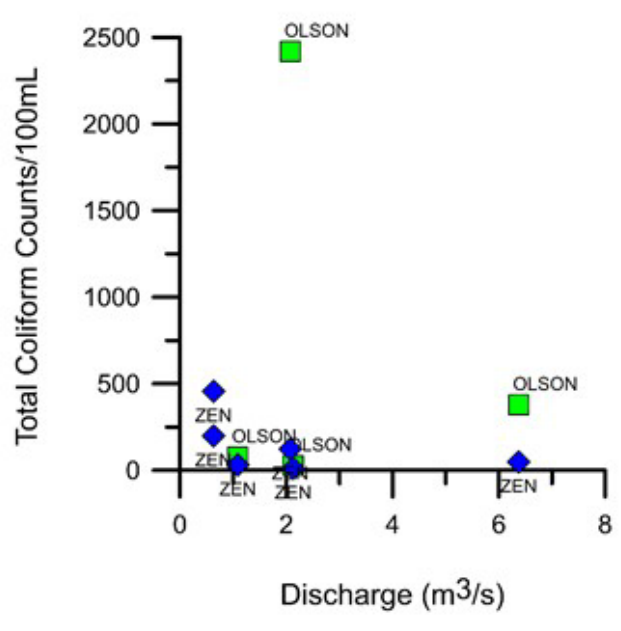

b)

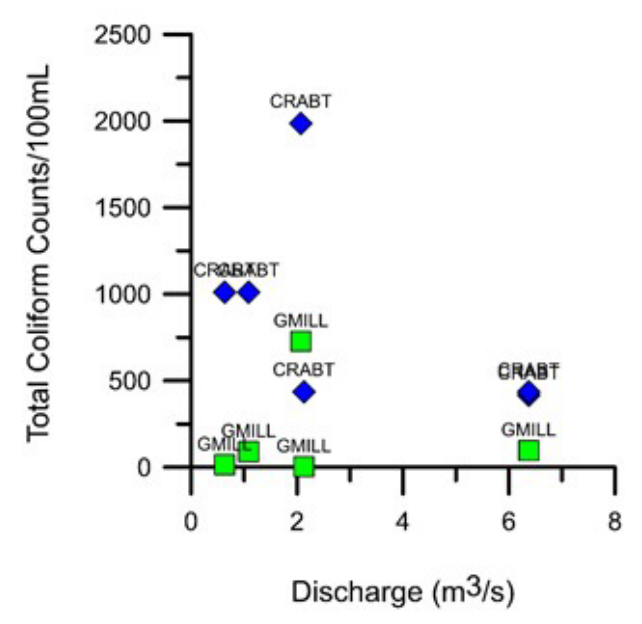

Clastic

Carbonate
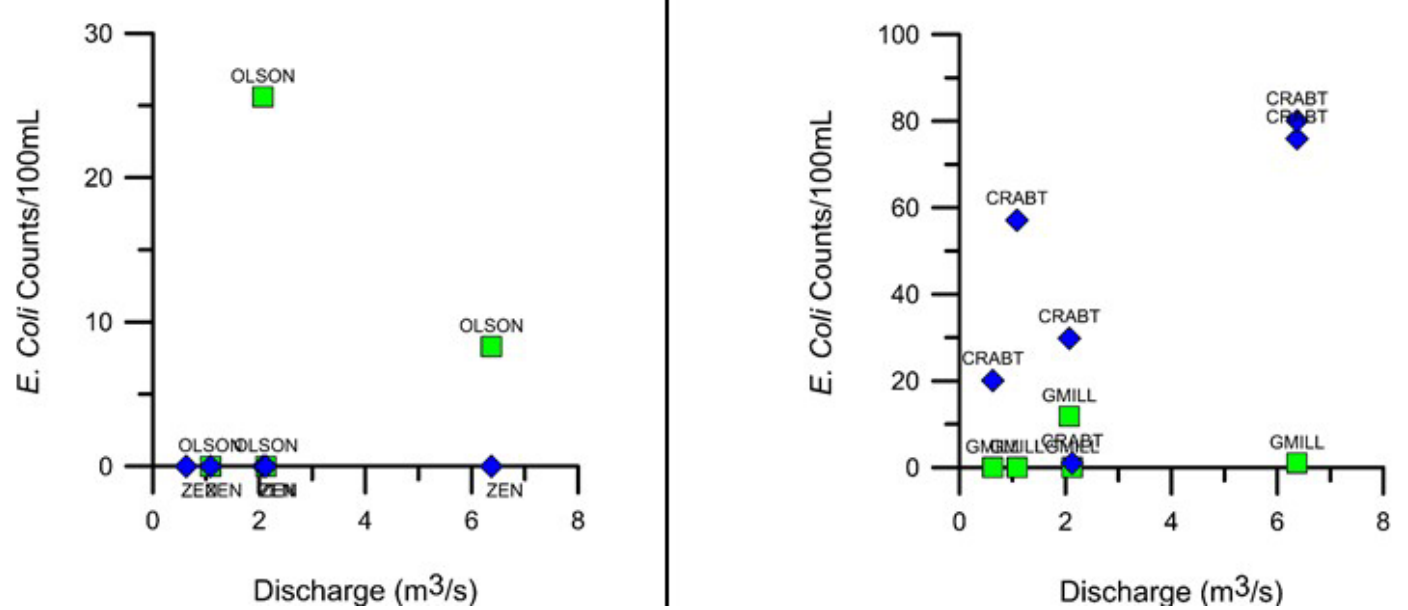

Figure 25: Total coliform and $E$. coli counts in indicator springs compared to measured total discharge. Data from OLSON and ZEN are plotted on the left (a) and data from GMILL and CRABT are plotted on the right (b). The thermal spring is not included due to pavement and spring pool influence. Analyte concentrations are graphed on y-axes and total discharge is graphed on $\mathrm{x}$-axes. Indicator springs are plotted according to spring grouping. 
a)

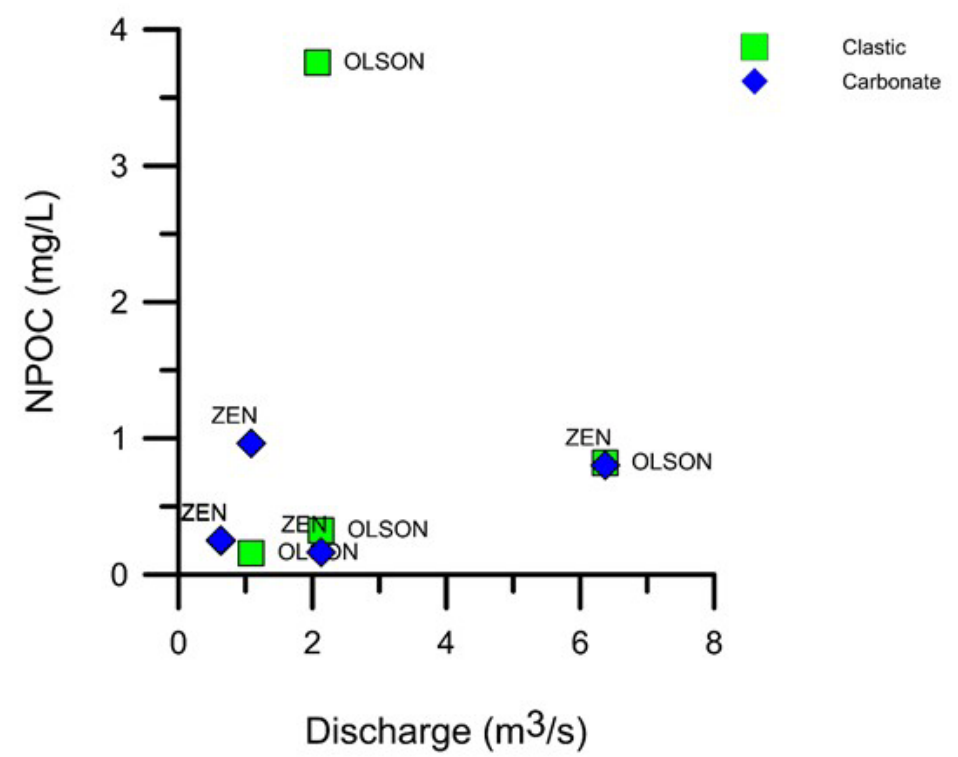

b)

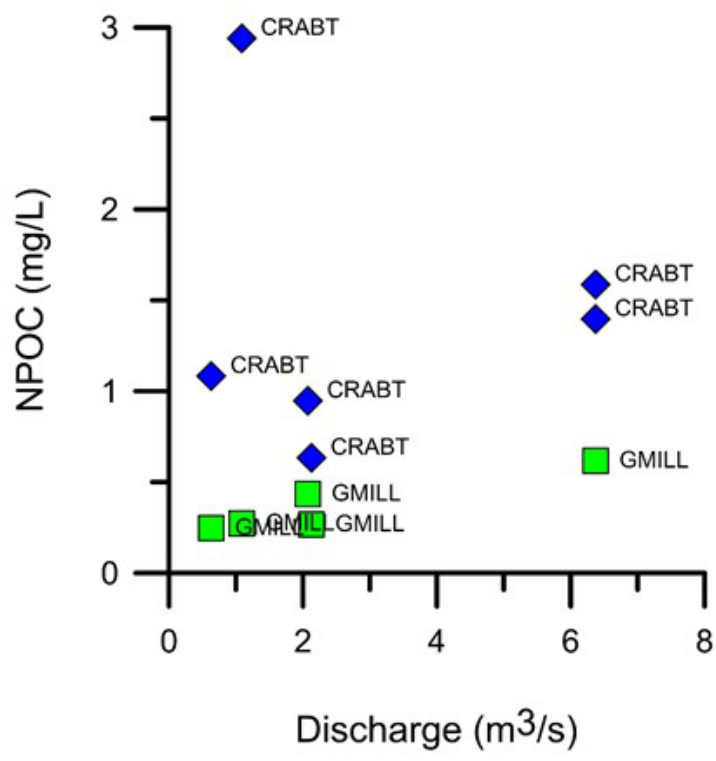

Figure 26: NPOC concentrations in indicator springs compared to measured total discharge. Data from OLSON and ZEN are plotted on the left (a) and data from GMILL and CRABT are plotted on the right (b). Analyte concentrations are graphed on $y$-axes and total discharge is graphed on $x$-axes. An outlier at ZEN spring (50.55 mg/L, 2.07 m3/s) was excluded. The thermal spring is not included due to pavement influence. Data symbols correspond to spring groups and discharge locations. 


\subsection{Discussion}

\subsection{Physical and Chemical Reconnaissance}

The overall distribution of springs and caves in Monroe County, WV involves the understanding of lithology, geologic structure and elevation. This physical and chemical reconnaissance expands spatially and comprehensively on previous studies completed in this area to understand this distribution. Richards (2006) identified approximately 250 springs along Peters Mountain, but was spatially limited to a $25 \mathrm{~km}$ range within the middle extent of the county. Among these springs, only 158 included pH and SC measurements and flow estimates; further, only 23 of these springs were analyzed once for major chemical constituents. Spring monitoring in this study incorporated $\mathrm{pH}$, SC, temp, alkalinity, major cations and anions as well as NPOC and bacterial indicator organisms. All springs were sampled multiple times; representative lithology springs were sampled more frequently assess temporal variation.

Richards recognizes the relationship between elevation, formation, and geologic structure in his classification of spring groups. Two signatures were identified within his Group 2 clastic springs (upper and lower Martinsburg signatures), and two chemical signatures within the Ordovician valley carbonate units: (1) Ca/Mg ratios ranging from 12 to 20 and (2) $\mathrm{Ca} / \mathrm{Mg}$ ratios around one (Richards, 2006).

The same general spring type and distribution is seen among the locations in this study. More extensive chemical sampling provided additional information. This study includes a geologic distinction within the Martinsburg Formation (lower Trenton Black River limestone and upper Reedsville shale); Richards' lower Martinsburg springs would be classified as carbonate springs in this study. In addition, this study shows clear chemical differences within the clastic springs identified as “upper Martinsburg Group 2 springs” (Richards, 2006). Ca/Mg ratios range from 10-18 within the Reedsville Formation. A dolomitic signature is also seen within valley carbonates, however, the limestone chemical signatures have much lower $\mathrm{Ca} / \mathrm{Mg}$ ratios (2 to 4) than reported in Richards (2006).

Similarities in calcite and dolomite saturation indices exist between OLSON, CRABT and $\mathrm{HATCH}$, potentially indicating a similarity in lithologies in their source areas (Figure 27). HATCH and CRABT both emerge from the New Market Formation; OLSON emerges from the Juniata Formation higher upslope on Peters Mountain. 


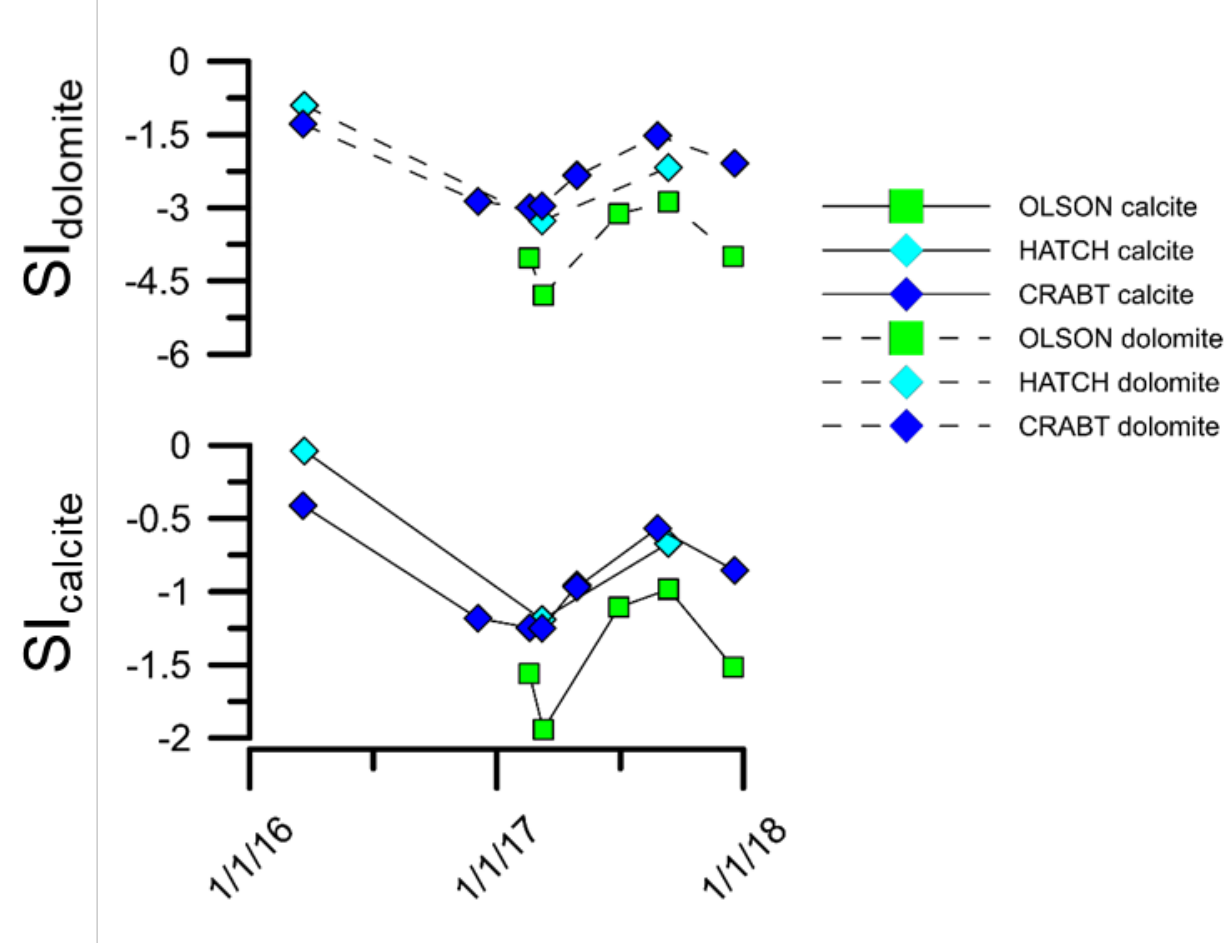

Figure 27: Regional comparison of calcite and dolomite saturation indices for OLSON, HATCH, and CRABT springs. 
Physical and chemical reconnaissance of greater spatial breadth and frequency in this study provide additional insight to previous studies along Peters Mountain. These measurements generally agree with the spatial distribution and chemical behavior of springs and caves seen previously in the region (Figure 7).

\subsection{Thermal Variability}

Spring temperature variations provide a surface-connection understanding through the quantification of recharge temperature signal propagation and can be used as a parameter for vulnerability characterization.

The combination/extent of style of recharge, storage and transmission make evaluation of springs in karst terrain inherently difficult. Temperature responses in these systems are a balance between advective and conductive heat transport (Manga, 2001); this balance depends on intrinsic properties of the rock, the volume of water, the flow regime and the flow rate (Benderitter et al., 1993; Manga, 2001). Water temperature variability reflects hydrogeochemical conditions and is a natural tracer in karst that is easily studied over long periods of time (Benderitter et al., 1993). Temperature responses in karst systems are a combination of two responses that vary by temporal scale: seasonal and storm responses. Storm responses have been the focus of spring characterization (Luhmann et al., 2011); seasonal responses have not be well constrained within karst systems.

Luhmann et al. (2011) characterized spring temperature responses in carbonate systems into 4 major patterns based on heat exchange; two patterns exhibiting localized recharge in thermal disequilibrium with the host rock and two patterns of distributed recharge in thermal equilibrium (Luhmann et al., 2011). Spring temperature responses are on a continuum, dependent on size of recharge events, and are likely to have different responses through time (Luhmann et al., 2011). Due to this complexity in aquifer dynamics and flow regimes, springs often exhibit more than one temperature pattern; assigning specific patterns is subjective and responses may fluctuate. In addition, distinguishing between patterns assigned by Luhmann (2011) is difficult without quantitative measure. It is more advantageous to identify how and when event-scale, seasonal and no temperature responses exist in springs, rather than assigning temperature patterns. 
Springs in this study were not assigned temperature patterns as per Luhmann et al. (2011). Cosine curve fitting has been used to evaluate diel nutrient cycling in other studies (Kurz et al., 2013; Riddell, 2015), but is utilized and adjusted in this study to evaluate temperature responses on an annual cycle. This approach involves the specific evaluation of temperature fluctuations in recharge and how these signals change upon interaction with individual spring systems. Cosine curve fit models provide quantitative measurements of this signal alteration; event-scale fluctuations and seasonal responses were evaluated through RSS, amplitude dampening factors and lag times. RSS is used as an indicator of event scale fluctuations not explained by seasonal trends. Amplitude dampening factors and lag times calculated from these curve fits provide a measure of connection to the surface; greater amplitude dampening factors and longer lag times indicate locations more independent from recharge temperatures, thus less vulnerable. Even though this approach is residence-timefocused and does not identify specific controls, it is still useful to adopt a general temperature regime within the context of the triple porosity model by White (2002) (Figure 28).

Most spring responses in this study have thermal variability on an annual scale, indicating lower residence times and the potential for either higher proportions of fracture and conduit porosity with fast infiltration rates, low storage, or fast transmission. Event scale fluctuation is also seen superimposed on the seasonal signal in a majority of the springs, evident in RSS values. Clastic springs show slightly faster residence times compared to other springs.

Thermal variability was seen within spring groups; but, similarities exist in springs outcropping in the same formation. Springs in the Reedsville Formation have a range of amplitude dampening factors (Figure 29). Elevations of springs within the Reedsville Formation are relatively similar except for OLDU which has an elevation of $713 \mathrm{~m}$. The larger amplitude dampening factors within this formation are found in the middle extent of Peters Mountain in Monroe County and lower amplitude dampening factors are seen in the southern extent. It is possible that a southern to northern increase in amplitude dampening factor exist, however the northern most Reedville spring plots closer to the southern extent relationship. 


\section{Temperature Responses}

\section{Thermal Equilibrium}

(Effective heat exchange)

Constant
Thermal Disequilibrium

(Ineffective heat exchange)

Event Scale Fluctuation

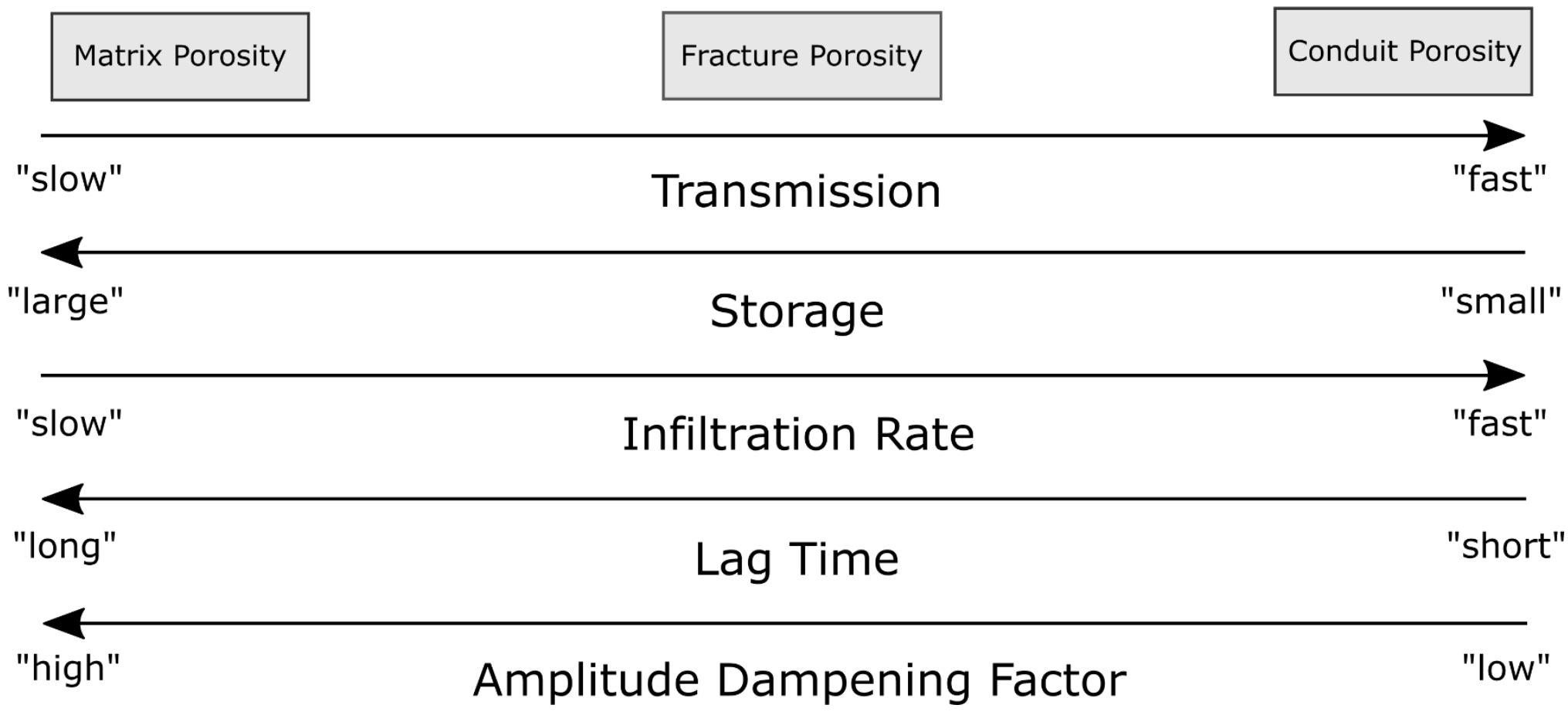

Figure 28: Temperature response schematic adapted from Luhmann et al. 2011 within the context of the triple porosity model (White, 2002). 




Figure 29: Amplitude dampening factors in clastic springs at various elevations within the Reedsville Formation. The blue oval represents Reedsville Formation springs in the middle extent of Peters Mountain located within 6 kilometers of each other. The red oval represents Reedsville Formation springs in the southern extent of Peters Mountain located within 12 kilometers of each other. OLDU spring is located in the northern most extent of Peters Mountain in Monroe County, 14 kilometers away from the northern most spring in the middle extent of the mountain. 
Overall, this application of cosine curve fit analysis is a simple way to attain quantitative measures of spring temperature profiles. This method is an inexpensive means of acquiring large amounts of data. This temperature evaluation method is relative and is advantageous for comparison between locations, but it may not be the most accurate method for identifying causes of specific thermal responses within individual springs.

\subsection{Overall Connection of Springs to Land Surface}

Springs are ubiquitously used in Monroe County for public and private water supply; Peters Mountain water "serves $>60 \%$ of the county's population" (pers. comm., ICWA Board of Directors, 2/7/2016). Because of the great reliance on spring water in Monroe County, assessing the vulnerability of these waters is imperative. Vulnerability classification is context specific and depends on the purpose and utilization of the spring itself.

A vulnerability matrix model based on risk and impact scores was created for the National Parks Service regarding rare, threatened and endangered species in Valley and Ridge karst (Vesper et al., 2018). This model focused specifically on human impact to the endangered species' habitats.

Van Beynen and Townsend (2005) created a holistic approach to understanding disturbance in karst terrains. Geomorphology, atmosphere, hydrology, biota, and culture were all evaluated to address aspects of potential vulnerability; specifically, parameters such as pesticide and herbicide concentrations, mineral and sediment removal in subsurface systems, changes in water table, and population density and richness of biota were included (Van Beynen and Townsend, 2005). This disturbance index focused on the potential for contamination based mostly on surface parameterization and has been tested in Florida, Southeast Italy and New Zealand; no studies were found applying this index to Appalachian karst. This karst disturbance index is extensive and relies on widespread information that may be costly to obtain.

The approach in this study highlights a simple way to identify/characterize spring connection to the surface; vulnerability is defined by rapid surface input. Springs with the closest and most rapid connection to surface activities are the ones most likely to be impacted by

human activities. This study provides a simple, preliminary, multi-parameter characterization of surface connection. This evaluation compares the springs in this study and may not be quantitatively applicable to springs in different locations; however, it is a good first-approach to 
understanding which springs should be studied further. This matrix can be re-evaluated with additional data and can be used in a variety of locations.

Two categories are included in this rapid surface input characterization: surface connection parameters and temperature signal propagation parameters. Surface connection measurements are evaluated based on response to recharge events and include total coliform and E. coli bacteria counts, NPOC concentrations, and $\mathrm{Ca}^{2+}$ concentrations. Temperature signal propagation measurements are evaluated based on temperature responses to recharge events and include the amplitude dampening factor and lag time calculated from cosine curve fits.

Surface connection and temperature signal propagation parameters were evaluated in this evaluation as follows (Table 12):

\section{Surface Connection Parameters}

1. Total coliform and E. coli bacteria counts

a. Monroe County is dominated by farm lands, thus total coliform and E. coli bacteria are sourced primarily from the land surface. Total coliform and E. coli bacteria counts will increase in runoff-fed springs directly following large recharge events. High elevation, non-karstic, forested springs may not exhibit as large of increases. Maximum total coliform and E. coli counts in each spring were used.

2. NPOC concentrations

a. NPOC is considered an indicator of surface connection (Charlier et al., 2012). NPOC concentrations will increase in springs directly following large recharge events. Maximum NPOC concentrations in each spring were used.

3. $\mathrm{Ca}^{2+}$ concentrations

a. $\mathrm{Ca}^{2+}$ concentrations are associated with rock-water interactions and are essentially undetectable in rainwater; they are often used as a signature of recharge propagation seen as a dilution in spring water concentrations. $\mathrm{Ca}^{2+}$ concentrations decrease directly following large recharge events. The ratio of maximum to minimum $\mathrm{Ca}^{2+}$ concentrations in each spring were used to represent $\mathrm{Ca}^{2+}$ signatures. 
Table 12: Individual Spring Surface Connection Index Evaluation

\begin{tabular}{|c|c|c|c|c|c|c|c|}
\hline \multirow[b]{2}{*}{ Location } & \multicolumn{2}{|c|}{$\begin{array}{c}\text { Temperature Signal } \\
\text { Propagation Parameters }\end{array}$} & \multicolumn{4}{|c|}{ Surface Connection Parameters ${ }^{a}$} & \multirow[b]{2}{*}{$\begin{array}{l}\text { Sampling } \\
\text { Frequency }^{c}\end{array}$} \\
\hline & $\begin{array}{c}\text { Amp. } \\
\text { Dampening } \\
\text { Factor }\end{array}$ & $\begin{array}{c}\text { Average } \\
\text { Lag } \\
\text { Time }\end{array}$ & $\begin{array}{c}\text { Ca } \\
\text { Max/Min } \\
\text { Ratio }\end{array}$ & $\begin{array}{c}\text { NPOC } \\
\text { Max } \\
(\mathrm{mg} / \mathrm{L})\end{array}$ & $\begin{array}{c}\text { Total } \\
\text { Coliform } \\
\text { Max }\end{array}$ & $\begin{array}{l}\text { E. coli } \\
\text { Max }\end{array}$ & \\
\hline \multicolumn{8}{|l|}{ Clastic } \\
\hline HANCK & 18 & 6 & 1.08 & 0.761 & 107.1 & 1.0 & twice a year \\
\hline $\mathrm{ECH}$ & 48 & 25 & 2.60 & 0.695 & 6.30 & 0.00 & twice a year \\
\hline BROY & 16 & 30 & 1.14 & 0.095 & 159.7 & 0.00 & twice a year \\
\hline OLSON & 9 & 33 & 1.94 & 3.76 & 2420 & 26 & monthly \\
\hline GMILL & 64 & 61 & 1.36 & 0.266 & 727.0 & 12 & monthly \\
\hline OLDU & 22 & 84 & 1.04 & 0.120 & 155.3 & 0.00 & twice a year \\
\hline LUGER & $\mathrm{n} / \mathrm{a}$ & $\mathrm{n} / \mathrm{a}$ & 1.22 & 0.775 & 11.0 & 0.00 & twice a year \\
\hline \multicolumn{8}{|l|}{ Carbonate } \\
\hline НАТСН & 15 & 32 & 1.49 & 0.891 & 1011 & 20 & twice a year \\
\hline CBRN & 19 & 42 & 1.45 & 1.23 & 272.3 & 8.5 & twice a year \\
\hline CRABT & 4 & 44 & 1.56 & 2.94 & 1986 & 80 & monthly \\
\hline DROPL & 23 & 46 & 1.40 & 0.829 & 218.7 & 3.1 & twice a year \\
\hline ZEN & $\mathrm{n} / \mathrm{a}$ & $\mathrm{n} / \mathrm{a}$ & 1.42 & 0.962 & 913.9 & 2.0 & monthly \\
\hline MEFF & $\mathrm{n} / \mathrm{a}$ & $\mathrm{n} / \mathrm{a}$ & 1.50 & 0.852 & 209.8 & 3.1 & twice a year \\
\hline \multicolumn{8}{|l|}{ Thermal } \\
\hline OLDSWT & 12 & 20 & 4.41 & 0.870 & 2420 & 23 & monthly \\
\hline Minimum & & & 1.04 & 0.095 & 6.3 & $0.1^{b}$ & \\
\hline
\end{tabular}


All surface connection measurements were normalized to the minimum value among all springs. Larger normalized values are indicative of springs with greater surface connection and greater vulnerability.

\section{Temperature Signal Propagation Parameters}

1. Amplitude dampening factor

a. Amplitude dampening factors are measures of weakened recharge temperature signals. Lower amplitude dampening factors are evident in springs with temperatures similar to recharge temperatures; these are associated with greater surface connection and vulnerability.

2. Lag time

a. Lag times indicate when maximum recharge temperature signals occur in springs. Shorter lag times are evident in springs with greater surface connection and vulnerability.

All temperature signal propagation parameters are extracted from cosine fit curve analysis.

A surface connection index utilizing all parameters mentioned above is summarized in Figure 30. Greater values for $\mathrm{Ca}^{2+}$ (Max/Min), NPOC, total coliform and E. coli bacteria count parameters indicate greater connection to the surface; lower values for amplitude dampening factor and lag time parameters indicate greater connection to the surface.

To compare surface connection at all spring locations quantitatively, a composite surface connection score was assigned by ranking all parameters. Springs were assigned a rank number in each parameter. The lowest ranking numbers in each parameter indicate the locations with the greatest surface connection. Total rank was evaluated by the sum of all parameter rankings. The lowest total ranking springs highly connected to the surface in this study were determined to be CRABT and HATCH (New Market Formation springs), and OLSON (Juniata Formation spring) (Table 13). OLDSWT was not included in this assessment; parameters evaluated in OLDSWT are likely a function of the spring pool and the paved surface surrounding the spring pool. ZEN, MEFF and LUGER were also not considered in the total of all parameter rankings due to missing or questionable temperature data. However, based on total chemical data rankings ZEN, MEFF and LUGER do not indicate a close connection to the surface. 


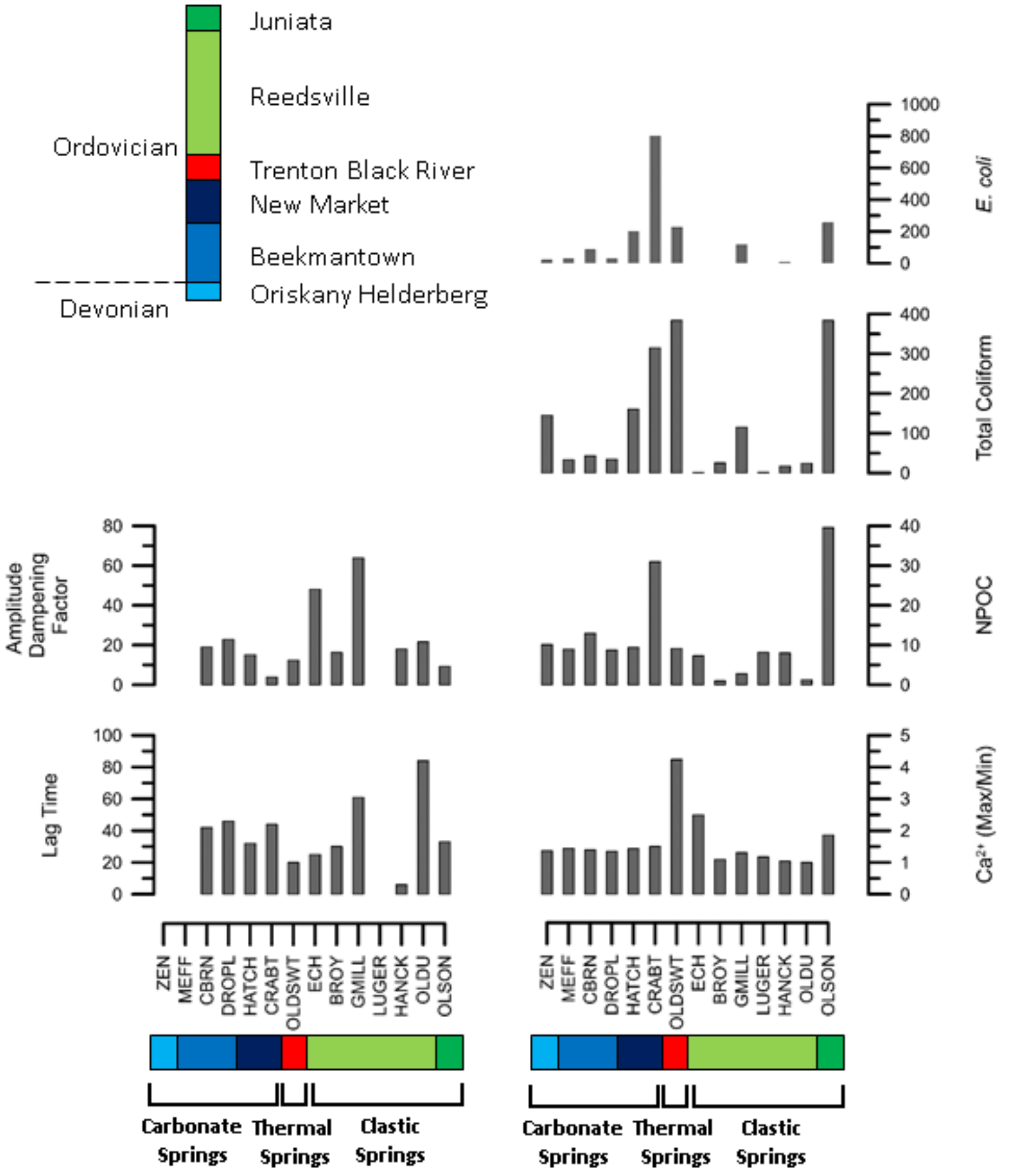

Figure 30: Characterization of surface connection in all spring locations. Locations are grouped by spring group, age and a relative cross sectional profile from $\mathrm{W}$ to E. Amplitude dampening factor and lag time are plotted on the left and $\mathrm{Ca}^{2+}$ (Max/Min), NPOC, Total coliform, and $E$. coli are plotted on the right. On the left, springs with high surface connection have low values; on the right, springs with high surface connection have high values. The surface connection parameters (Ca Max/Min, NPOC, Total coliform, and $E$. coli) are normalized to the minimum value among all springs. OLDSWT data are questionable due to surface input and the spring pool. See discussion in text. 
Table 13: Composite Surface Connection Ranking

\begin{tabular}{|c|c|c|c|c|c|c|c|}
\hline \multirow[b]{2}{*}{ Location } & \multicolumn{2}{|c|}{$\begin{array}{c}\text { Temperature Signal } \\
\text { Propagation Parameters }\end{array}$} & \multicolumn{4}{|c|}{ Surface Connection Parameters } & \multirow[b]{2}{*}{$\begin{array}{l}\text { Tota } \\
\text { Rank }\end{array}$} \\
\hline & $\begin{array}{l}\text { Amp. } \\
\text { Dampening } \\
\text { Factor }\end{array}$ & $\begin{array}{l}\text { Average Lag } \\
\text { Time }\end{array}$ & $\begin{array}{c}\text { Ca } \\
\text { Max/Min } \\
\text { Ratio }\end{array}$ & $\begin{array}{c}\text { NPOC } \\
\text { Max } \\
(\mathrm{mg} / \mathrm{L})\end{array}$ & $\begin{array}{l}\text { Total } \\
\text { Coliform } \\
\text { Max }\end{array}$ & $\begin{array}{c}\text { E. coli } \\
\text { Max }\end{array}$ & \\
\hline \multicolumn{8}{|l|}{ Clastic } \\
\hline HANCK & 5 & 1 & 12 & 10 & 11 & 9 & 48 \\
\hline $\mathrm{ECH}$ & 9 & 2 & 1 & 11 & 13 & 10 & 46 \\
\hline BROY & 4 & 3 & 11 & 5 & 9 & 10 & 42 \\
\hline OLSON & 2 & 5 & 2 & 1 & 1 & 2 & 13 \\
\hline GMILL & 10 & 9 & 9 & 12 & 5 & 4 & 49 \\
\hline OLDU & 7 & 10 & 13 & 13 & 10 & 10 & 63 \\
\hline LUGER & $\mathrm{n} / \mathrm{a}$ & $\mathrm{n} / \mathrm{a}$ & 10 & 9 & 12 & 10 & $\mathrm{n} / \mathrm{a}$ \\
\hline \multicolumn{8}{|l|}{ Carbonate } \\
\hline НАТСH & 3 & 4 & 5 & 6 & 3 & 3 & 24 \\
\hline CBRN & 6 & 6 & 6 & 3 & 6 & 5 & 32 \\
\hline CRABT & 1 & 7 & 3 & 2 & 2 & 1 & 16 \\
\hline DROPL & 8 & 8 & 8 & 8 & 7 & 6 & 45 \\
\hline ZEN & $\mathrm{n} / \mathrm{a}$ & $\mathrm{n} / \mathrm{a}$ & 7 & 4 & 4 & 8 & $\mathrm{n} / \mathrm{a}$ \\
\hline MEFF & $\mathrm{n} / \mathrm{a}$ & $\mathrm{n} / \mathrm{a}$ & 4 & 7 & 8 & 6 & $\mathrm{n} / \mathrm{a}$ \\
\hline $\begin{array}{l}\text { Shaded values } \\
\text { "n/a" values ar } \\
\text { Bolded and bo } \\
\text { Note, ZEN, MI } \\
\text { OLDSWT was }\end{array}$ & $\begin{array}{l}\text { tied ranks; tied } \\
\text { ed when data w } \\
\text { ues indicate the } \\
\text { d LUGER were } \\
\text { luded due to inf }\end{array}$ & $\begin{array}{l}\text { nks are reported } \\
\text { ot available/ev } \\
\text { est total ranked } \\
\text { t considered for } \\
\text { nce of paved su }\end{array}$ & $\begin{array}{l}\text { repeated ran } \\
\text { ated } \\
\text { cations } \\
\text { erall total ras }\end{array}$ & 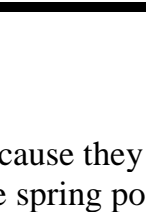 &  & 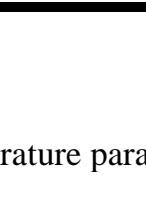 & \\
\hline
\end{tabular}


Springs in this study were analyzed at different frequencies. An additional composite surface connection ranking was computed for all spring locations to evaluate the effect of sampling frequency. NPOC, $\mathrm{Ca}^{2+}$ (Max/Min), and total and E.coli bacterial count data were subsampled to include only sampling events where all springs were sampled for all parameters. The dates of the subsampled events include:

- $\quad$ March $20^{\text {th }}, 21^{\text {st }}$, and $22^{\text {nd }}$ of 2016 (only $\mathrm{Ca}^{2+}$ Max/Min);

- March $9^{\text {th }}, 10^{\text {th }}$, and $11^{\text {th }}$ of 2017 ; and,

- $\quad$ September $11^{\text {th }}, 12^{\text {th }}$, and $13^{\text {th }}$ of 2017

The lowest total ranking springs were determined to be HATCH (New Market Formation), OLSON (Juniata Formation), and CBRN (Beekmantown Formation). Two of the three springs were similarly identified as the most connected to the surface; however, the identification of CBRN instead of CRABT spring as the most total vulnerable, suggests that frequency has an impact on the total ranking results, especially in carbonate springs.

This approach to identifying surface connection in springs is a simple, good first-step method to identify springs with greater potential for contamination. Total surface connection rankings should be evaluated in detail for each location to ensure that missing data do not provide a false indication of vulnerability. 


\subsection{Conclusions}

This study provides the ICWA and land owners with two available databases for future reference. Geology, land cover, hillshades, watersheds, and surface streams are also included.

A variety of chemical and physical signatures were seen among springs and discharge locations. Clastic and carbonate springs in this study are classified as calcium-magnesiumbicarbonate waters with neutral $\mathrm{pHs}$ and alkalinities; the thermal spring is classified as a calcium-magnesium-sulfate-carbonate water with low $\mathrm{pH}$, high SC and high alkalinity, associated with deep flow along the St. Clair thrust fault. As expected, discharge locations represent a combination of all spring chemistries with slightly higher $\mathrm{pHs}$ associated with degassing of the carbonate waters.

Spring thermal responses are a function of connection to the surface, thermal properties of the rock, residence times, and capture zone. Cosine curve fit analysis was successful in determining annual temperature patterns in most springs. ZEN and LUGER cosine fit curves were not able to be compared to other springs due to jumps in data associated with installation of a new logger (ZEN) and non-annual thermal patterns (LUGER), however, overall temperature fluctuations at these locations are still useful. Modeling temperatures with a cosine curve allowed for a deeper understanding of temperature variability. Average lag times are similar between carbonate and clastic springs, thus cannot be used to indicate residence time. Carbonate springs have lower overall amplitude dampening factors, indicating a higher degree of thermal disequilibrium with the surrounding rock and a greater connection to the surface. Some clastic springs also have low amplitude dampening factors, assumed to be a function of smaller high elevation spring-sheds. The thermal spring exhibits both event scale and seasonal fluctuation; event scale fluctuation is likely associated with the surrounding concrete enclosure.

Installed staff gages, well points, and flow measurements allowed for an estimation of total water associated with Peters Mountain. Individual stream contribution is consistent yearround and highest flows measured occurred in April. Rating curves were successfully created for all locations, although QIND was never adjusted to creek bottom due to staff gage installation error. This study was successful in providing a range of water availability, however it is likely that more water exists and is unaccounted for due to budget limitations and associated error.

Springs along Peters Mountain have a mixture of deep and shallow waters with varying flow regimes, and thus various contamination propensities. A composite surface connection 
assessment was completed encompassing multiple parameters: surface connection was measured through $\mathrm{Ca}^{2+}$, NPOC and E. coli and total coliform bacterial counts; temperature signal propagation was evaluated by lag times and amplitude dampening factors. A composite vulnerability ranking identified CRABT, HATCH and OLSON as the most vulnerable springs among those sampled.

This study provides the first step in understanding these springs over long periods of time and a vulnerability assessment that will aid in budgeting for allocation and protection of these remarkable waters. 


\subsection{Limitations and Future Work}

Various isotopic analyses could be done in the future to provide data to this vulnerability assessment. Oxygen and Deuterium stable isotopes $\left({ }^{18} \mathrm{O}\right.$ and $\left.\mathrm{D}\right)$ provide insight on spring interaction. In comparison to oxygen and hydrogen stable isotopes, Sr isotopes are not convoluted by fractionation with the atmosphere and are therefore a useful tracer of water-rock interactions (Lyons et al., 1995). Sr often substitutes for calcium in minerals due to the similarity in atomic radius. Rocks enriched with calcium bearing minerals will exhibit higher amounts of Sr if substitution takes place

Additional geologic mapping should be done in areas where mapped formation locations and chemical signatures disagree; specifically, ZEN and CBRN springs. ZEN currently plots in the Oriskany-Helderberg Formation, but according to $\mathrm{Ca} / \mathrm{Mg}$ ratios and consistent temperature data is more likely a dolomitic spring sourcing from the Beekmantown Formation. CBRN currently plots in the Brallier Formation but has a carbonate chemical signature and temperature response like other carbonate springs.

The installation of additional data loggers will increase the resolution of the data in this study. Barometric pressure loggers at all discharge locations would eliminate the heterogeneity of pressure across the county and the installation of a weather station in the Peters Mountain area would improve the accuracy of rainfall amount and timing and thus the interpretations of thermal patterns in the springs.

Potential errors in discharge evaluation are associated with changing stream channel profiles, estimations of maximum stream depth used to adjust stage, the need for well point reinstallation due to destructive high flow events, and variable logger elevation position within well points. Elimination of staff gages altogether and the sole utilization of well points for stagedischarge comparison would decrease complication in the future. Because of the associated errors with the logger data and mediocre stage-discharge relationships, discharge evaluation in this study should not be used as standalone data. For this study, discharges were sufficient to observe how analytes move through surface systems.

Finally, LiDAR data in Monroe County became available toward the end of this project. The utilization of these data would aid in the delineation of spring-sheds and adjacent sinkholes to springs. This delineation could aid in supporting/rejecting the interpretation of surface connection based on temperature and NPOC and E. coli and total coliform bacterial counts. 


\subsection{References}

Adams, D., 2015, December 3. Pipeline opponents cite contamination of drinking water supply as cautionary tale. The Roanoke Times. Retrieved from http://www.roanoke.com/business/news/pipeline-opponents-cite-contamination-ofdrinking-water-supply-as-cautionary/article_1172b929-8960-54a6-abdc1784023dd5b9.html

Benderitter, Y., Roy, B. and Tabbagh, A., 1993. Flow characterization through heat transfer evidence in a carbonate fractured medium: first approach. Water Resources Research, 29(11): 3741-3747.

Buchanan, T.J., and Somers, W.P., 1969, Discharge measurements at gaging stations: U.S. Geological Survey Techniques of Water-Resources Investigations, book 3, chap A8, 65 p. (Also available at https://pubs.usgs.gov/twri/twri3a8/.)

Charlier, J.-B., Bertrand, C. and Mudry, J., 2012. Conceptual Hydrogeological Model of Flow and Transport of Dissolved Organic Carbon in a small Jura Karst System. Journal of Hydrology, 460: 52-64.

Colilert ${ }^{\circledR}$. 2016. In IDEXX. Retrieved July 24, 2016, from https://www.idexx.com/water/products/colilert.html

Dasher, G., Schaer, N. and Garlock, T., 2018. Rich Creek Cave. The West Virginia Caver, 36(1): 3-7.

Dean, S.L., Kulander, B.R. and Skinner, J.M., 1988. Structural Chronology of the Alleghanian Orogeny in southeastern West Virginia. Geological Society of America Bulletin, 100(2): 299-310.

Dean, S.L. and Kulander, B.R., 1992. Geological Investigation of Gap Mills Spring Area, Monroe County, West Virginia. Prepared for the office of Environmental Health Services Division of Public Health in the state of West Virginia.

Geologic Units in Monroe County, WV. In Mineral Resources Online Spatial Data. Retrieved January 21, 2018, from https://mrdata.usgs.gov/geology/state/fips-unit.php?code=f54063

Grabow, W.O.K., 1996. Waterborne diseases: Update on water quality assessment and control. Water SA, 22(2): 193.

Hemple, J., 1975. Caves and karst of Monroe County, West Virginia. West Virginia Speleological Survey Bulletin, 4: 149. 
Homer, C., Dewitz, J., Yang, L., Jin, S., Danielson, P., Xian, G., Coulston, J., Herold, N., Wickham, J. and Megown, K., 2015. Completion of the 2011 National Land Cover Database for the conterminous United States-representing a decade of land cover change information. Photogrammetric Engineering \& Remote Sensing, 81(5): 345-354.

Indian Creek Watershed Association Mission, 2016. In Indian Creek Watershed Association. Retrieved July 23, 2016, from http://indiancreekwatershedassociation.org/mission

Kurz, M.J., de Montety, V., Martin, J.B., Cohen, M.J. and Foster, C.R., 2013. Controls on diel metal cycles in a biologically productive carbonate-dominated river. Chemical Geology, 358(0): 61-74.

Langmuir, D., 1971. The geochemistry of some carbonate ground waters in central Pennsylvania. Geochimica et Cosmochimica Acta, 35(10): 1023-1045.

Luhmann, A.J., Covington, M.D., Peters, A.J., Alexander, S.C., Anger, C.T., Green, J.A., Runkel, A.C. and Alexander, E.C., 2011. Classification of thermal patterns at karst springs and cave streams. Groundwater, 49(3): 324-335.

Lyons, W.B., Tyler, S.W., Gaudette, H.E. and Long, D.T., 1995. The use of strontium isotopes in determining groundwater mixing and brine fingering in a playa spring zone, Lake Tyrrell, Australia. Journal of Hydrology, 167(1): 225-239.

Manga, M., 2001. Using springs to study groundwater flow and active geologic processes. Annual Review of Earth and Planetary Sciences, 29(1): 201-228.

McColloch, J.S., 1986. Springs of West Virginia, V-6A. West Virginia Geological and Economic Survey, Charleston, WV, 493 pp.

McDowell, R.C. and Schultz, A.P., 1990. Structural and stratigraphic framework of the Giles County area, a part of the Appalachian Basin of Virginia and West Virginia.

Moore, J.E., 2012. Potential inhibitors and sources of error in the measurement of travertine precipitation rates in a karst stream influenced by thermal mineral waters. MS Thesis, West Virginia University, 127 pp.

NADP WV04 Site, 2018. National Atmospheric Deposition Program database of daily precipitation, bucket weight, temperature, and optical sensor. Preliminary data, subject to revision. Retrieved from http://nadp.slh.wisc.edu/siteOps/ppt/default.aspx

Oregon Water Science Center, USGS. 2013. Alkalinity Calculator. Retrieved 7/3/2017 from https://or.water.usgs.gov/alk/index.html 
Parkhurst DL, Appelo CAJ (1999) PHREEQC (Version 2) - Users guide for a computer program for speciation, batch-reaction, one-dimensional transport, and inverse geochemical calculations U.S. Geological Survey Water Resources Investigation Report 99-4259, pp. 326.

Richards, B.G., 2006. Aqueous Geochemistry of Springs along Peters Mountain in Monroe County, WV. MS Thesis, West Virginia University, 64 pp.

Riddell, J.L., 2015. Comparing Diel Cycles of Dissolved Inorganic Carbon to Diel Cycles of Fe and Mn at a Coal Mine Drainage Site in Harrison Co., WV. MS Thesis, West Virginia University, 124 pp.

RSPSD Board Members, 2014, December 3. Statement of the Red Sulphur Public Service District board members to the Monroe County commission. [Letter to the Monroe County Commission].

Sturms, J.M., 2008. Surficial Mapping and Kinematic Modeling of the St. Clair Thrust Fault, Monroe County, West Virginia. MS Thesis, West Virginia University, 91 pp.

Van Beynen, P. and Townsend, K., 2005. A disturbance index for karst environments. Environmental Management, 36(1): 101-116.

Vesper, D.J., Smaldone, D. and Feller, D.J., 2018. Assessing the relative vulnerability of sensitive karst habitats containing rare, threatened, and endangered species in the Chesapeake and Ohio Canal National Historical Park. Park Science, 34-1(Winter 20172018): 60-69.

White, W.B., 1988. Geomorphology and Hydrology of Karst Terrains. Oxford University Press, New York, 464 pp.

White, W.B., 1993. Analysis of Karst Aquifers. In: W.M. Alley (Editor), Regional GroundWater Quality. Van Nostrand Reinhold, New York, pp. 471-489.

White, W.B., 2002. Karst hydrology: recent developments and open questions. Engineering Geology, 65(2-3): 85-105.

WVGES Chart. 2014. Generalized Stratigraphic Chart for West Virginia. Map 29-A 2014. No vertical scale implied. Retrieved from http://www.wvgs.wvnet.edu/www/images/GenStratChartWV20151113.pdf 
Yakub, G.P., Castric, D.A., Stadterman-Knauer, K.L., Tobin, M.J., Blazina, M., Heineman, T.N., Yee, G.Y. and Frazier, L., 2002. Evaluation of Colilert and Enterolert defined substrate methodology for wastewater applications. Water Environment Research, 74(2): 131-135. 


\section{APPENDIX A}

\section{DETAILED FORMATION DESCRIPTIONS}




\section{Time (oldest at the bottom)}

\section{Mississippian}

Mauch Chunk Series

Greenbrier Formation

Pocono Maccrady Series

\section{Devonian}

Chemung Formation

Brallier Formation
Descriptions (compiled from McDowell and Shultz, 1990; Dean and Kulander, 1992; the WVGES Generalized WV Stratigraphy, 2014; and Geologic Units, 2018)

Includes the Bluefield Formation and the Hinton Formation. The Blu efield Formation is an argillaceous, fossiliferous limestone and calcareous shale interbedded with gray to green clay that grades into a micaceous green to maroon shale and mudstone. Few interbeds of sandstone and siltstone. Upper Bluefield has no fossils and contains thin coal beds. The Hinton Formation is a red, green and gray arenaceous shale and calcareous siltstone. This formation contains few, thin fossiliferous limestone and coal beds and has a hard resistant quartzite at the base (also called the Stony Gap) that pinches out in Northeastern Monroe County.

Is a medium to dark gray oolitic or fossiliferous calcilutite and calcisiltite with minor interbeds of calcareous shale and siltstone. Dark gray to black irregularly bedded chert is also present.

Consists of the Price Formation, the Maccrady shale and the Pocono Group. The Price Formation is a mostly terrigenous, coal bearing, planar crossbedded, feldspathic and micaceous sandstone that commonly contains lithic fragments. Base of the formation contains a light gray quartz pebble conglomerate. Abundant siltstone and shale or mudstone up section. Two coal seams mid-section. This formation underlies Little Mountain in Monroe County. Kreisa and Bamback (1973) labels the formation as a regressive sequence of 8 lithofacies from marine shelf to delta plain and swamp. The Maccrady shale interfingers with the Price Formation and is a reddish brown shale and siltstone. The Pocono Group is a gray massive sandstone with little shale input. The Pocono Group and Maccrady shale are often mapped undivided.

A thick bedded, fine-grained, slightly calcareous sandstone with siltstone and shale interbeds. Contains mainly brachiopod fossils and sole marks. Possible turbidite deposit of a proximal flysch (marine) facies.

Consists of a cyclic brown, fine-grained sandstone, light gray to green siltstone, and minor amounts of light gray shale. The shale is sparsely fossiliferous and silty. The amount of 
Millboro Series

Oriskany-Helderberg Series

\section{Silurian}

Clinton Series sandstone and thickness of all beds increase from about 3 inches at the base to 1.5 feet at the top. The upper contact is gradational.

Includes the Huntersville Chert and the Millboro shale. These formations interfinger and are difficult to distinguish in eastern WV. Huntersville Chert is a massive and irregularly bedded, fractured light to dark gray chert, and is also called the Onondaga Chert/Formation. The Millboro shale consists of the Marcellus shale, the Mahantango shale, and the Harrell shale in eastern WV. It is a thick sequence of olive-gray to gray black, fissile shale, containing sparse fossils. The upper contact is gradational and total thickness is difficult to determine.

Consists of the Helderberg Group and the Oriskany sandstone (equivalent to the Rocky Gap sandstone). The Helderberg Group consists of mostly cherty limestone. Some sandstone and shale input is seen. This group contains the Keyser Formation, the Clifton Forge sandstone, and the Big Mountain shale. The Oriskany sandstone is light brown, calcareous, friable, coarse-grained, crossbedded sandstone. It is mostly ferruginous or maganiferous and forms flatirons. Also contains vugs of brachiopods and crinoids. Very weatherable due to the calcite cement.

Includes the Rose Hill Formation, the Keefer Ssndstone and the Tonoloway limestone. The Rose Hill Formation is a dark grayish, medium grained red hemetitic sandstone and small amounts of fossiliferous siltstone and shale interbeds. Some sandstone beds are greenish gay and mottled. This is most likely a transgressional lagoon facies. The Keefer sandstone is a light gray, fine to coarse grained sandstone and quartzite. Contains local crossbeds, ripple marks and skilithos burrows. Interlayered with minor reddish-brown sandstones. The Tonoloway limestone is very thin and poorly exposed. Presence is indicated by reddish-brown clayey soil, small sinkholes, and distinct slope breaks. Lower section contains cyclic, finegrained, fossiliferous limestone, dark gray silty and calcareous shale, and dark gray massively bedded limestone. The upper portion is thinly laminated calcareous dark-gray siltstone and shale, fine grained cross-laminated sandstone and minor fossiliferous limestone. In some areas of Monroe County, the Tuscarora sandstone and the Clinton Series are mapped as one unit due to a combination of poor exposure and stratigraphic thinning. 
Tuscarora Formation

\section{Ordovician}

Juniata Formation

Reedsville Formation

Trenton/Black River Formation

New Market Formation

Beekmantown Formation
A "very distinctive ledge forming othroquartzite". Light gray, fine to coarse grained sandstone with a high percentage of quartz grains. Deposited in medium to thick beds with well sorted grains. Trough and planar crossbedding, skilithos and arthrophycus burrows are present. Can contain minor quartz pebble conglomerate lenses. Gradational contacts with the Juniata Formation (below) and the Rose Hill Formation (above). Combination of marine and fluvial depositional environments, but more commonly fluvial.

A fine grained gray to red sandstone with crossbedding, interbedded with red clay shale lower in the formation and minor gray/red fissile siltstone and shale in the upper section. Reduction spots are commonly seen. Delta-plain mudflat depositional environment.

Consists of interbedded shale, calcareous siltstone and sandstone. The upper member of the Martinsburg Series. Shallow marine deposit.

Contains both the Trenton limestone and the Black River limestone. They are grouped together in this thesis. Is a fossiliferous, gray, fine grained, thin to medium bedded limestone with interbeds of calcareous shale and siltstone. The Trenton limestone grades upward into the Reedsville shale. Lower member of the Martinsburg Series. Shallow marine deposit.

Consists of the Blackford Formation, the Elway Ls and the Five Oaks Ls (from oldest to youngest). The Blackford Formation consists of interbedded dolomite, minor dolomitic limestone and red to gray mudrock. The basal bed is a breccia/conglomerate with angular to subrounded clasts of gray to black chert. The Blackford Formation is a common sinkhole former. Elway Ls and the Five Oaks Ls are light to medium gray limestones.

Is a thick sequences of cherty, light to medium gray, fine to medium grained dolomite with sparse interbeds of fossiliferous limestone and dolomitic cemented sandstone. Chert commonly found in the uppermost portions as interbeds and nodules in the lower portions. Marine shelf carbonate depositional environment. Also referred to as the Knox Group 


\section{APPENDIX B}

SITE LOCATION DESCRIPTIONS 
Table B1: Site Location Descriptions

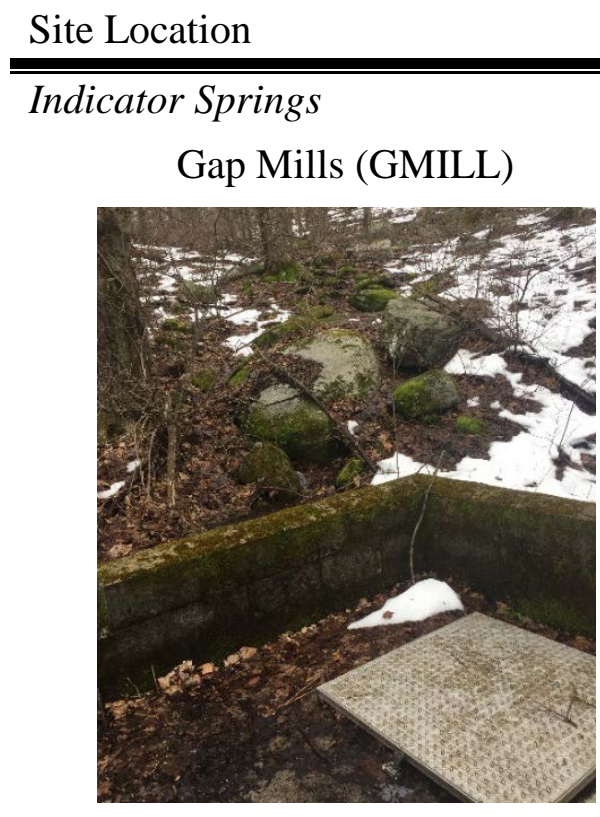

UTM (Zone 17N) Other Names (if any)

Description

Olson Peters Spring (OLSON)



553283

4154045

526239

4139250
This spring is the current public water supply spring for the town of Gap Mills and the backup water supply for the Sweet Springs Valley

Bottling Company, located at 1598 Rowan Rd in Gap Mills, WV. The spring is approximately a mile south of the bottling company amid a range of vegetation, from grass fields to dense forest cover. The spring itself is contained in a concrete spring box with a locked stainless steel cover. Samples were taken from the spring box. The spring in located within the Ordovician Reedsville shale and sits at $875 \mathrm{~m}$ in elevation.

This spring is owned by Dana Olson and Jana Peters, about $0.40 \mathrm{~km}$ from the Appalachian Trail and the boarder of West Virginia and Virginia. The spring is the main source of drinking water for the owners. It has an elevation of $847 \mathrm{~m}$ and outcrops at the Ordovician Juniata sandstone/Reedsville shale contact. Samples are taken from the concrete spring box pictured.

**Nancy Bouldin and Dana Olson pictured** 




541537

4150812

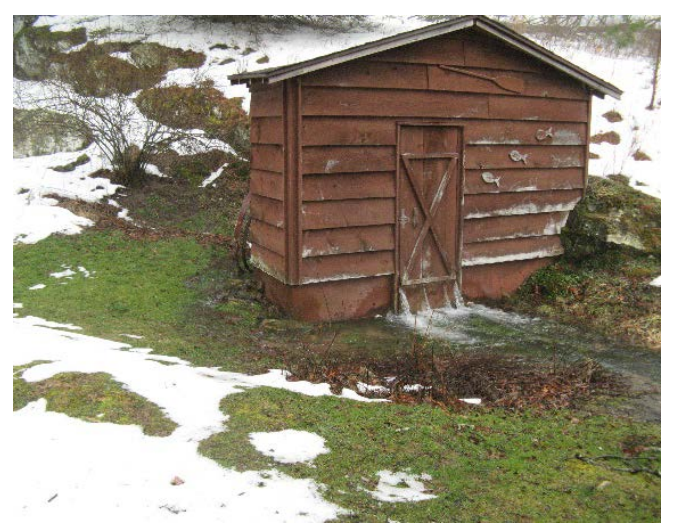

This spring was previously owned by Jeff Young and his wife Jill, now overseen by caretaker James Crews. The spring is located in a complex, not well-mapped geologic region of Monroe County. The spring plots at the contact of the Devonian Oriskany sandstone (part of the Rocky Gap sandstone Group in McDowell and Shultz) and the Huntersville Chert (part of the Huntersville-Marcellus Formations). The Rocky Gap sandstone is calcareous and easily weatherable. The Huntersville Chert is massively bedded dark-gray chert about $15 \mathrm{~m}$. thick. The springhouse sits at an elevation of $667 \mathrm{~m}$. The spring was used by owners Jeff and Jill for drinking water and heating and is now currently being explored as a bottled water source by the new owner. Spring samples were taken inside the spring house. The spring is within close proximity to Dropping Lick Cave. 
Old Sweet Spring (OLDSWT)
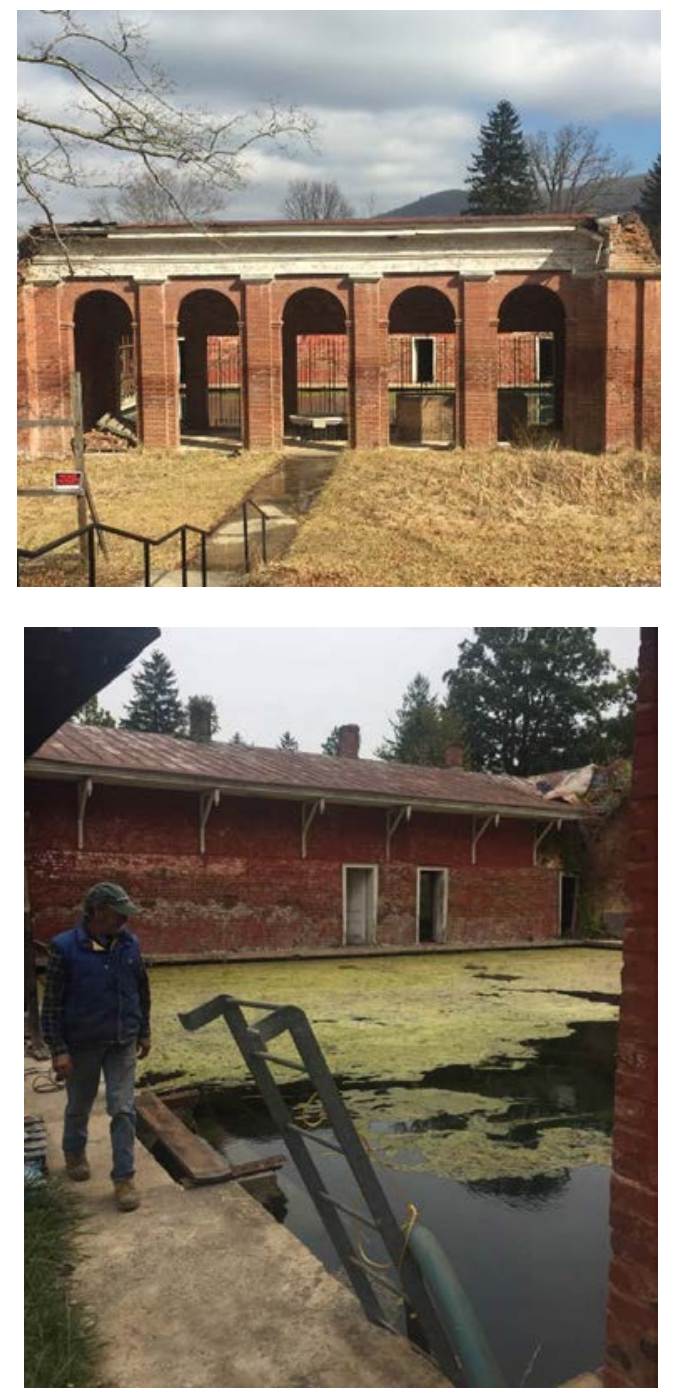

ID Number 52 from
Prince and others

1936 (McColloch, 1986)
Old Sweet spring is a historic thermal mineral spring located in the northeastern portion of Monroe County in the town of Sweet Springs.

The historic spring was an established hotel resort beginning in 1792 and was the "first spring resort in southeastern, WV" (Robinson, 2007). The resort was visited by the elite, visitation at its high pre-Civil War. Old Sweet Springs was bought by the state of West Virginia in 1945 and functioned as a retirement home until 1991

(Robinson, 2007). It is currently owned by Ashby Berkley who is looking to restore the buildings. The property's caretaker is Ricky Lucas. The spring flows from the Trenton/Black River limestone at an elevation of $613 \mathrm{~m}$. The gaseous, warm, upwelling water is likely associated with deep upward movement along the St. Clair thrust fault. The thermal water is collected in a large pool, previously used for bathing. Samples were taken from the thermal pool to the left of the ladder in the bottom picture - shortly before the water discharges from the pool and not at the base of the pool.

**Howdy Henritz pictured in the bottom photo** 
Crabtree Spring (CRABT)

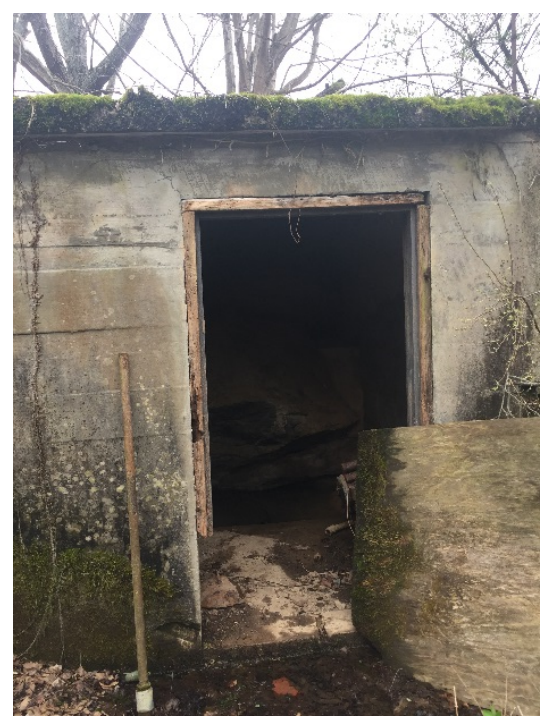

Other Locations

Luger Spring (LUGER)

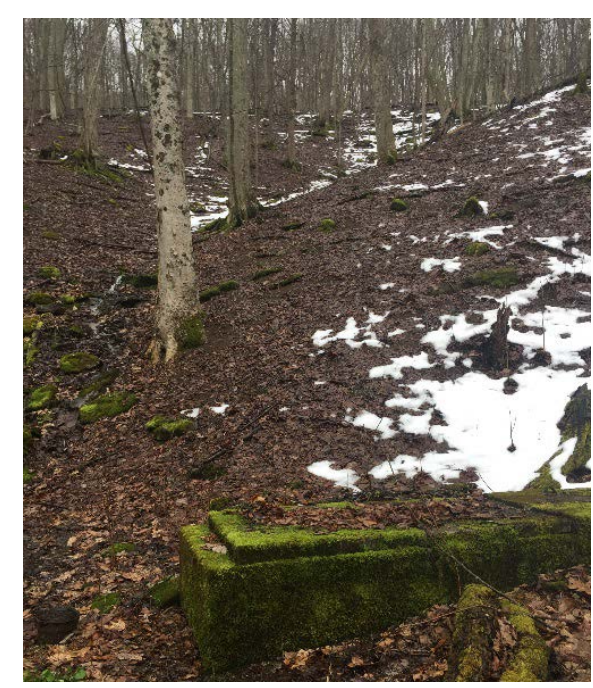

527430

4141264

550460

4152395
This spring is owned by Roger and Becky Crabtree and is located off of Wilson Mill Rd. in

Lindside, WV. The spring is enclosed in a spring house previously used by the home owners as the major source of running water; the spring is no longer used. Samples were taken from inside the spring house. The spring is surrounded by outcropping bedrock and numerous sinkholes can be seen on the Crabtree property. The spring surfaces in the Ordovician St. Paul/Beekmantown limestone at an elevation of $645 \mathrm{~m}$.

This spring is a public water supply option for the town of Union. The spring is located off of Zenith Rd. in Gap Mills on the Luger family's property. At an elevation of $906 \mathrm{~m}$, the spring outcrops at the Juniata sandstone/Reedsville shale contact. The water is collected in a concrete spring box approximately 12 'x4'. Samples were taken from inside the spring box. A dipper was necessary most sampling trips due to low water elevation in the box. 
Dropping Lick Cave (DROPL)

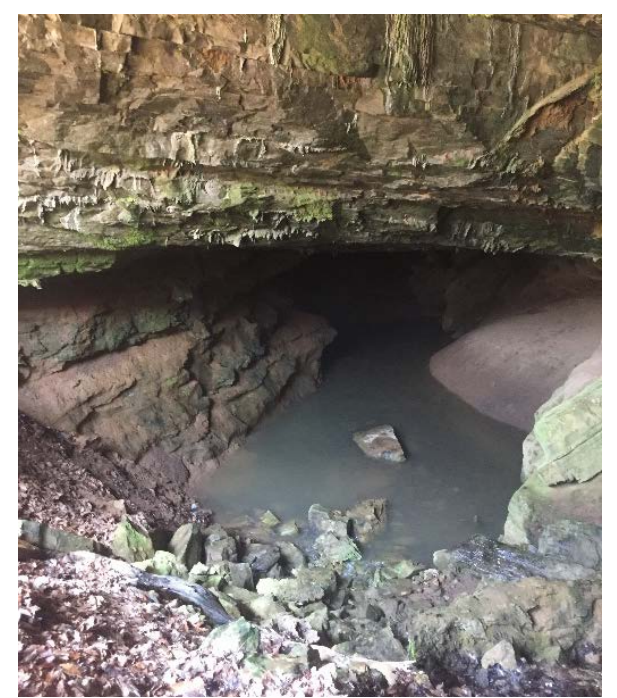

Hancock Spring (HANCK)

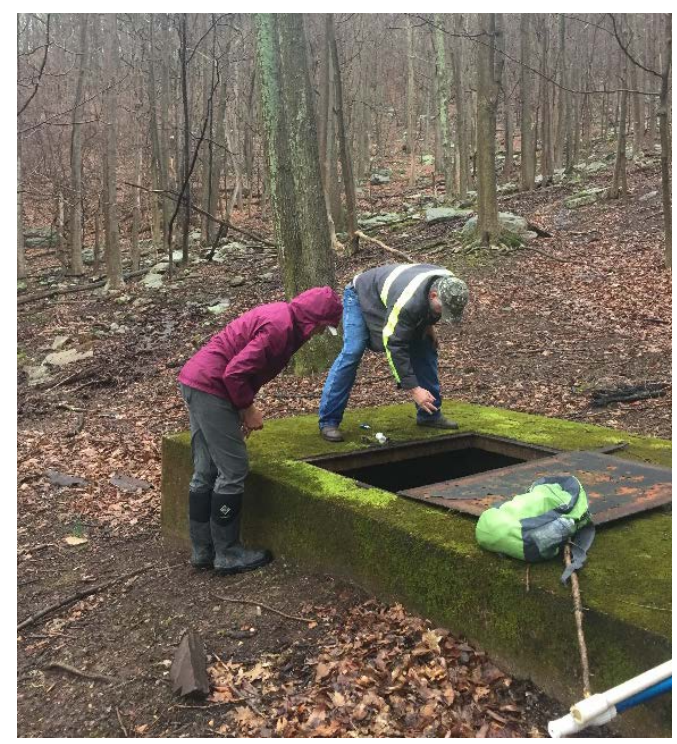

Dropping Lick

Spring, ID P113 from

Erskine 1948, USGS

Groundwater

542176

4150538

520161

4136647 Database, Chisholm and Frye 1976

(McColloch, 1986)

McClung Zenith Cave by Alderson

(Hemple, 1975)

Red Sulphur PSD Spring 2 (McColloch,
This cave is located of Zenith Rd. in Gap Mills about $0.32 \mathrm{~km}$ southeast of Dorothy Shires' home with associated trout ponds. The opening of Dropping Lick Cave is approximately $40 \mathrm{~m}$. wide, with a $30 \mathrm{~m}$. drop of cave breakdown the cave bottom. Exposed bedrock and massive 1986) sediment deposits flank the sides of the cave. A 6

$\mathrm{m}$. wide stream flowing from east to west disappears under the entrance of the cave and emerges downstream as Dropping Lick Stream.

Samples were taken at the base of the cave breakdown where the cave stream disappears.

The cave is located within the Ordovician

Beekmantown limestone at 740 m elevation.

This spring is located in the southern most portion of Monroe County in Peterstown. It is the uppermost public water supply spring for the town of Red Sulphur and is contained by a concrete spring box about $5 \mathrm{~m} \times 4 \mathrm{~m}$. Samples were taken from the spring box. A dipper was necessary for most sampling trips due to low water elevation in the spring box. It comes to the surface at the contact between the Reedsville shale and the Juniata sandstone. Hancock spring is about $1 \mathrm{~km}$ east of Coburn spring at an elevation of $782 \mathrm{~m}$.

**Nancy Bouldin and Porter Robertson pictured** 
Coburn Spring (CBRN)

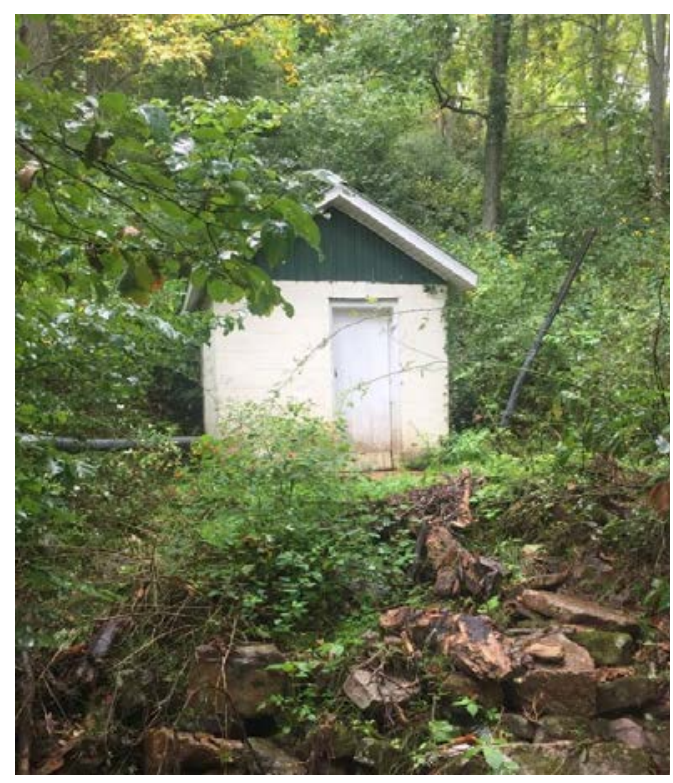

Broyles Spring (BROY)

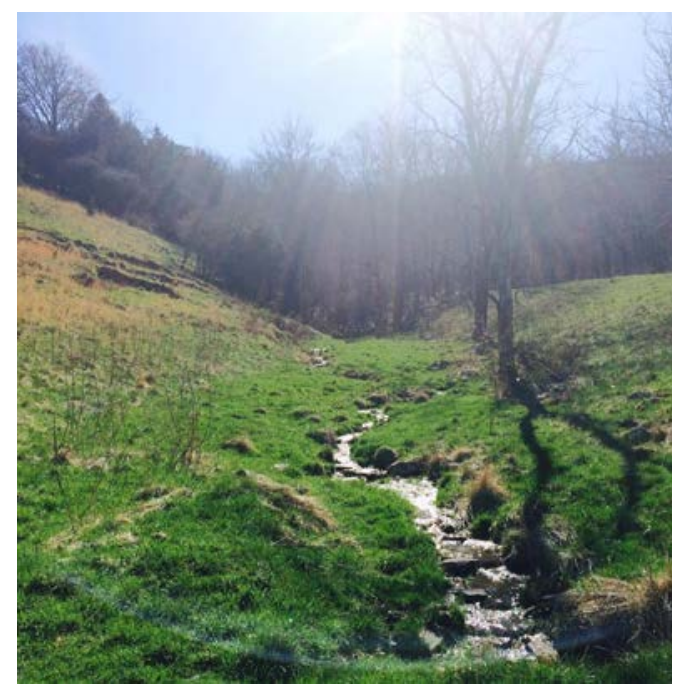

519758

4137569

Red Sulphur PSD Spring 1 (McColloch, 1986)

530822

4142284
This spring is a public water supply spring for Red Sulphur, located outside Peterstown and below Hancock Spring at an elevation of $585 \mathrm{~m}$.

This spring is gathered in a newly renovated springhouse on the border between Virginia and West Virginia. The underlying geology consists of mixed upper Devonian shales (Brallier,

Chemung and Price Formations). This spring currently plots in the Brallier shale, however exhibits a carbonate signature and will be referred to as a carbonate spring plotting in the Beekmantown Formation in this paper. This discrepancy is likely due to a combination of potential error in the geologic map and GPS coordinates.

Broyles spring is located on the property of William Broyles, approximately $1.5 \mathrm{~km}$ southeast of the junction of Bradley Cemetery Rd. and Spruce Run in the town of Lindside. The spring is used for cattle and drinking water. It flows from the Martinsburg shale but likely is associated with the Juniata sandstone due to weatherability of the Martinsburg shale at the surface. The spring is sampled downslope of the true outflow at a plastic "springbox" (elevation $817 \mathrm{~m}$.). Samples were taken from this "springbox". The true spring source must be further upslope on Peters Mountain.

*picture looking up elevation of the spring* 
Echols Spring $(\mathrm{ECH})$

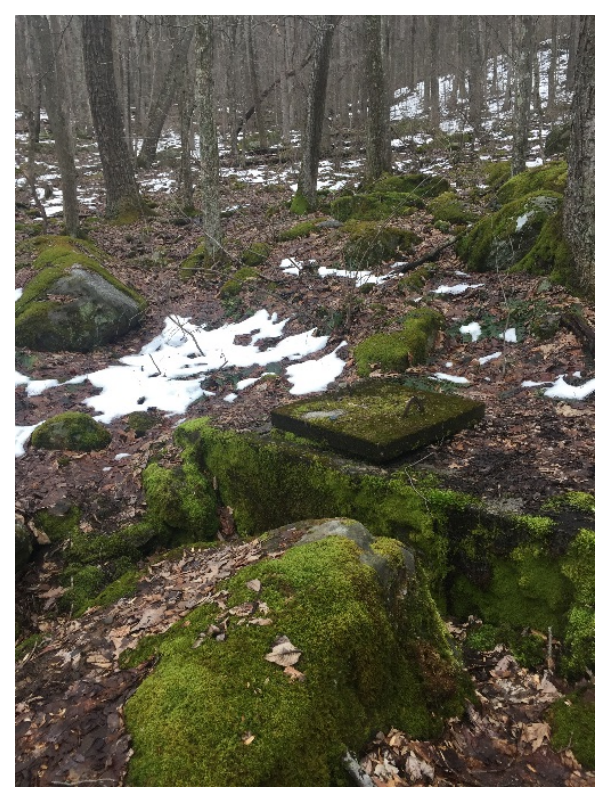

Old Sweet Springs Upper (UPPER)

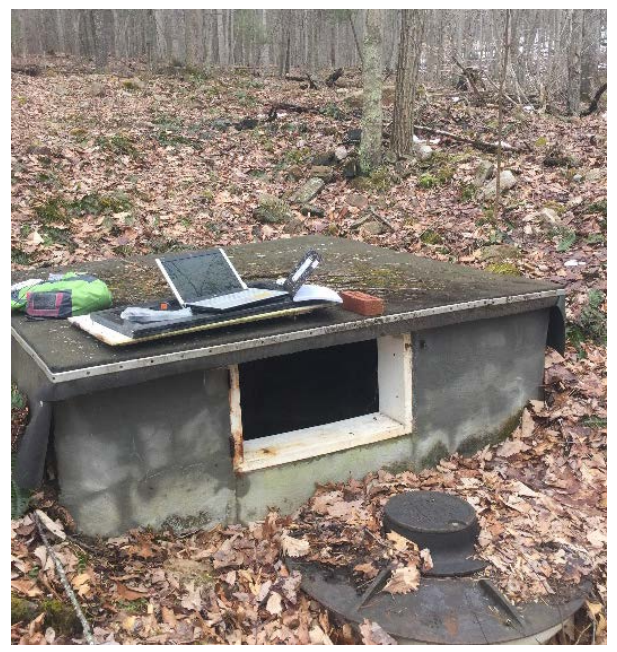

555567

4155883

567629

4164180
This spring is located about $2.75 \mathrm{~km}$. southeast of the intersection of Crowder Rd. and Rt. 3 (Sweet Springs Valley Rd.). It was previously used as the public water supply for the town of Gap Mills and is on the property of Larry and Pam Echols. It is a boulder fed spring on the slope of Peters Mountain that collects in a $\sim 2 \mathrm{~m} \mathrm{x} 2$ m concrete spring box. Samples were taken from this spring box. A dipper was necessary for most sampling trips due to the low water elevation in the spring box. The spring outflows in the Martinsburg Formation at an elevation of $875 \mathrm{~m}$.

This spring is located on the Sweet Springs Resort property upslope from the thermal water pool. It is one of many upper springs on the property and is used for drinking water at the resort. This spring is located $1.0 \mathrm{~km}$. southeast of thermal Old Sweet Spring at a higher elevation on Peters Mountain. It is contained in a $2 \mathrm{~m} \mathrm{x} 2 \mathrm{~m}$ concrete springbox and outflows from the Martinsburg Shale at 713 m elevation. Samples were taken inside the spring box. 
Trout Hatchery Cave (HATCH)

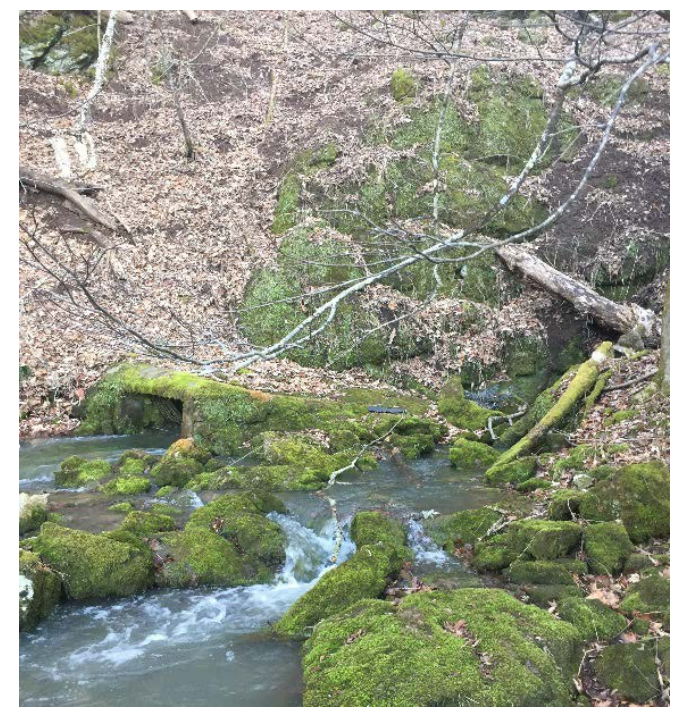

Miss Effie Cave (MEFF)

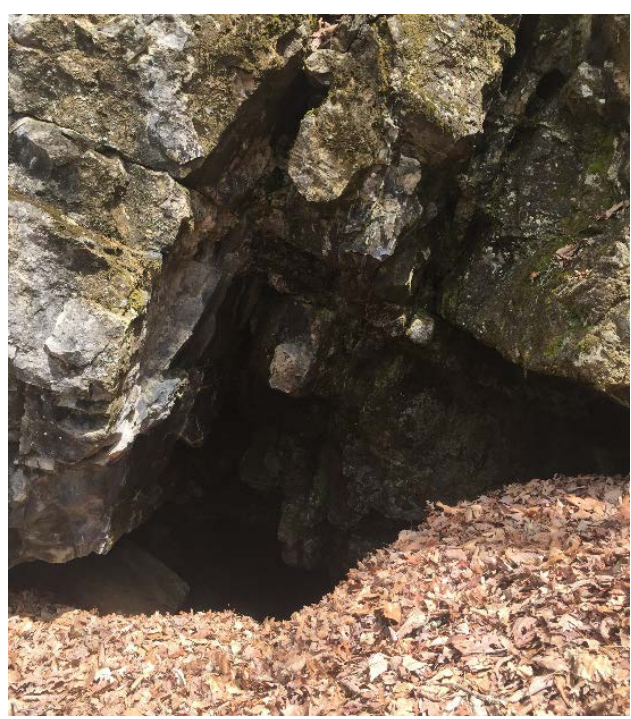

Rich Creek Cave,

Rich Creek Spring, ID P111 from

526483

4140742

536393

4147714 Groundwater

Database, Chisholm and Frye 1976

(McColloch, 1986)

Rock Camp Cave , Rock Camp Spring, ID P112 from

Groundwater and Frye 1975
This cave is located $0.15 \mathrm{~km}$ southeast from the Mercer Anglers Club trout fish hatchery, off of Wilson Mill Rd. in the town of Lindside. This property is currently owned by Parker King. The cave feeds the ponds used for in the hatchery.

The opening of the cave is $0.5 \mathrm{~m}$ wide and set

Erskine 1948, USGS

back $15 \mathrm{~m}$ from the largest pond that collects the water for downstream use. Cave opening is approximately $1 \mathrm{~m}$ x $1 \mathrm{~m}$. Samples are collected inside the cave within a meter of the cave opening. The cave is located at the

Beekmantown/St. Paul limestone boundary at an elevation of $635 \mathrm{~m}$.

Ersakine 1948, USGS

Database, Chisholm

(McColloch, 1986)

Rock Camp Cave by Pearlsburg (Hemple, 1975)
This cave is located off of Pete Amos Rd., approximately $2.5 \mathrm{~km}$ after the intersection of Rt. 219 (Seneca Trail Rd.). The cave opening is located on Bobby Surface's property. The cave is a meandering system within the Beekmantown limestone at an elevation of $685 \mathrm{~m}$. Samples are collected from the furthest point of cave access without crawling (approximately 3 meander loops into the cave). The water sinks beneath the opening of the cave and emerges $7 \mathrm{~m}$ away as Rock Camp Creek. 


\section{Discharge Locations}

Sweet Springs Creek (QSWT)

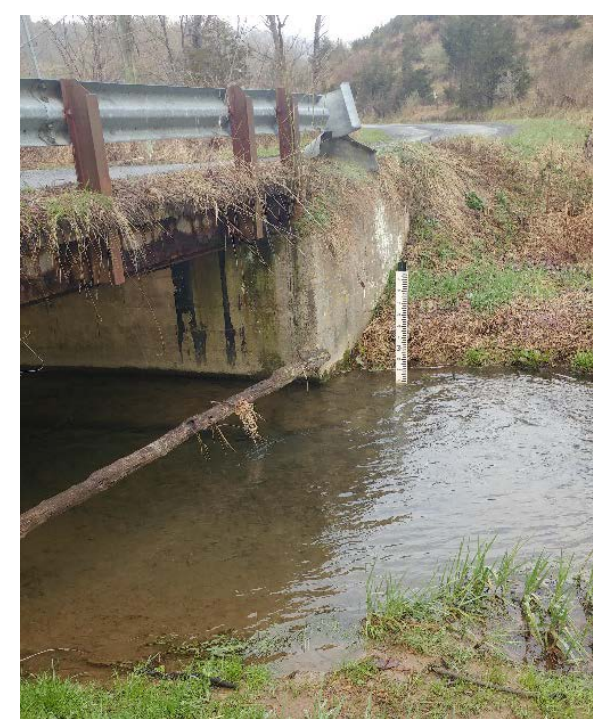

Second Creek (QSEC)

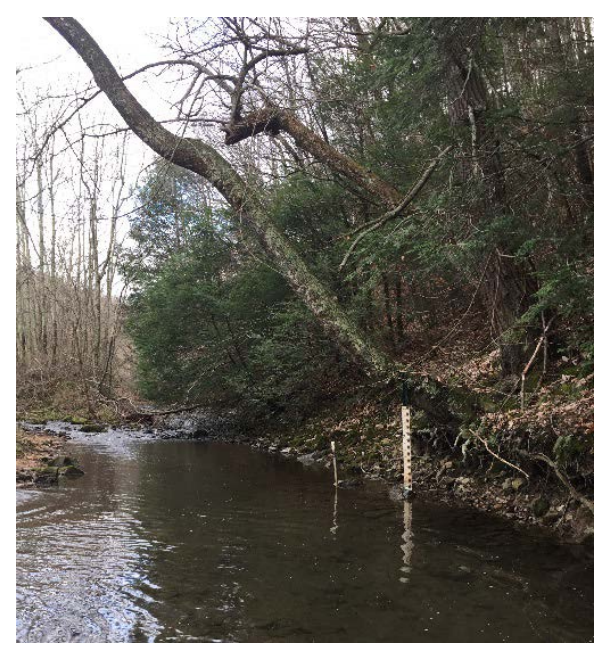

566375

4164792

551628

4157728
This discharge location is on the property line between Roland and Paul Carter. The staff gage was installed under the northeast corner of the bridge. Sweet Creek has an even, non-rocky stream bottom. Flow is measured approximately

$15 \mathrm{~m}$. downstream of the bridge. Dense watercress and foliage are present 5-10 ft. west of the bridge, upstream of the gaging location.

This discharge location is behind an abandoned warehouse, approximately $0.2 \mathrm{~km}$ from Rt. 3 and southeast of a large grassy field. The property is owned by Sonja Looney. The staff gage was installed 5 meters upstream from the open field on an overhanging tree. The stream has a bedrock bottom, making staff gage installation difficult. Limestone and shale bedrock outcrops in the stream and on the western bank. 
Indian Creek (QIND)

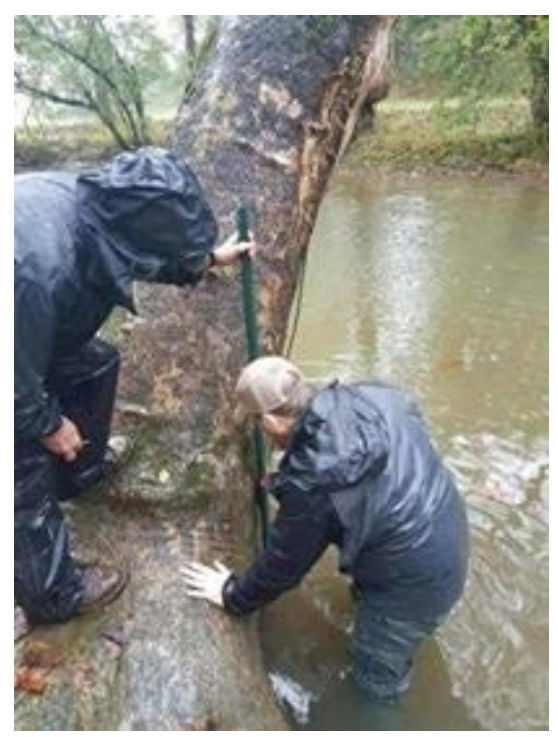

This discharge location is on the property of Dave Hawks in Lindside just south of the intersection of Greenville Rd. and Rt. 219 (Seneca Trail Rd.). The staff gage was installed on a hanging tree approximately $60 \mathrm{~m}$. downstream of the confluence of Rock Camp Creek and Indian Creek. Stream flow is measured $10 \mathrm{~m}$. downstream of the intersection of these two creeks, above the staff gage. The stream has a rocky, uneven bottom with points of noticeably different flow velocity. Lush vegetation exists along both banks. An ephemeral beaver damn is located approximately $6 \mathrm{~m}$. upstream of Indian Creek before the intersection; discharge data may be effected during its presence.

**Howdy Henritz and Travis Wilson pictured** 
Rich Creek (QRCH)

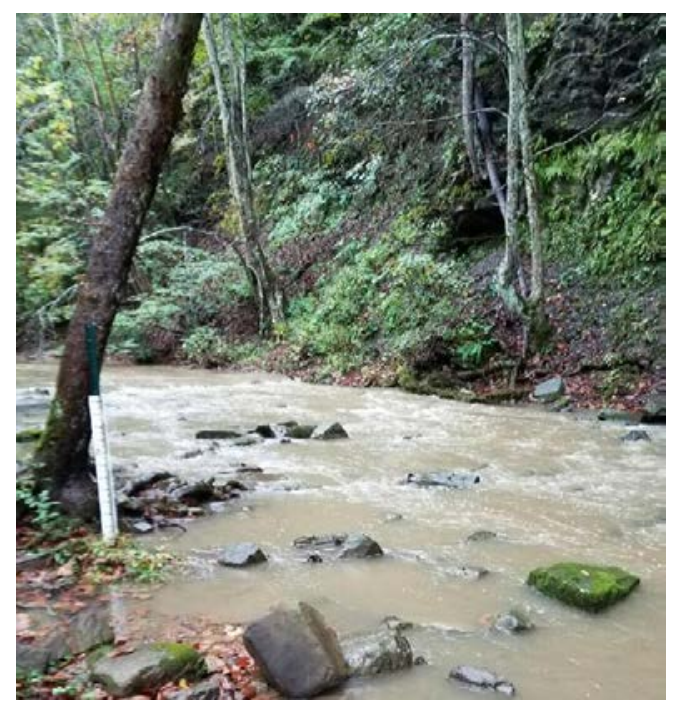

529893

4147664
This discharge location is on Brenda Lively's private property in Peterstown on the boarder of Virginia and West Virginia. The United States Geologic Survey (USGS) had a previously working gaging station off of the bridge approximately $1.75 \mathrm{~km}$ downstream of this location. The USGS is currently working to encompass this gaging station in their study of Monroe County water budget. The staff gage was installed on a tree adjacent to the north bank of the stream, behind a small cabin. Discharge was measured approximately $15 \mathrm{~m}$. downstream of the staff gage. The southern bank of the stream contains a huge bedrock outcrop of the Bluefield shale. The stream has a rocky bottom with an uneven flow distribution, especially at low flows. 
Hans Creek (QHAN)

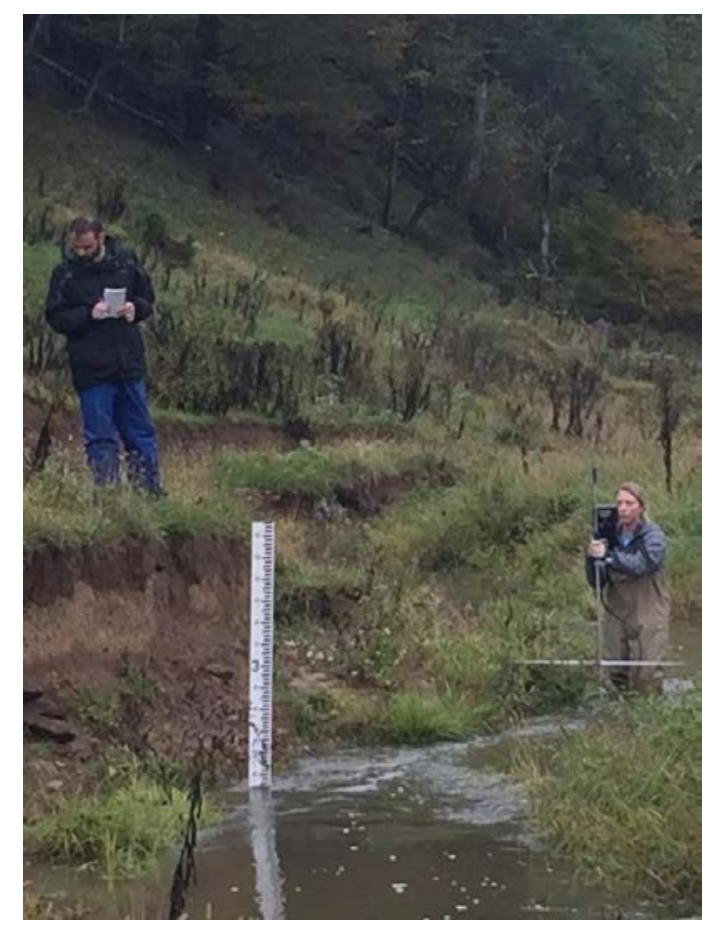

517725

4138802
This discharge location is on William Broyles' property, located $0.25 \mathrm{~km}$. south of the intersection of Cooks Run Rd. and Rt. 219

(Seneca Trail Rd.) in Lindside. Two tributaries meet to form Hans Creek at the staff gage installation point. Discharge was measured approximately 7 meters downstream of the staff gage installation. The stream flows west, typically under low flow conditions, however there is Evidence of major flooding and bank erosion. The stream contains vegetation and input from cow pastures adjacent to the sampling site.

*Jonney Mitchell and Emily Bausher pictured* 


\section{APPENDIX C}

TABULATED DISCHARGE DATA 
Table C1: QRCH Adjusted Stage and Discharge

\begin{tabular}{|c|c|c|c|c|c|c|c|c|c|c|c|c|}
\hline Date & Time & G & УG & $\begin{array}{c}\mathbf{H}_{\text {staff }} \\
\text { (m) }\end{array}$ & $\begin{array}{l}\text { D from } \\
12 / 4 / 2016 \\
\text { (m) }\end{array}$ & $\begin{array}{c}O F F_{\text {staff }} \\
\text { (m) }\end{array}$ & $\begin{array}{c}\mathbf{H}_{\text {stream }} \\
\text { with } \\
\text { OFF } \\
\text { (m) }\end{array}$ & $\begin{array}{l}\mathbf{H}_{\text {stream }} \\
\text { with } \\
\text { OFF }_{\text {staff }} \\
\text { and } \\
\text { OFF logger } \\
\text { (m) }\end{array}$ & $\begin{array}{c}\text { Hstream }_{\text {strith }} \\
\text { with } \\
\text { OFF staff, } \\
\text { OFFlogger } \\
\text { and final } \\
\text { manual } \\
\text { offset } \\
\text { (m) } \\
\end{array}$ & $\begin{array}{c}\text { Average } \\
\text { Discharge } \\
\left(\mathbf{m}^{3} / \mathbf{s}\right)\end{array}$ & $\begin{array}{l}\text { Average } \\
\text { \% Error }\end{array}$ & $\begin{array}{c}\text { Average } \\
\text { Error } \\
\text { (m) }\end{array}$ \\
\hline 0/8/2016 & 15:00 & 1.29 & 1.17 & 0.118 & 0.549 & 0.501 & 0.619 & 0.536 & & 0.977 & 5.57 & 0.054 \\
\hline $12 / 4 / 2016$ & $12: 00$ & 1.22 & 1.17 & 0.048 & 0.549 & 0.501 & 0.549 & 0.466 & & 0.366 & 5.67 & 0.021 \\
\hline 2/19/2017 & 11:15 & 1.16 & 1.17 & -0.012 & 0.549 & 0.501 & 0.489 & 0.406 & 0.456 & 0.335 & 5.75 & 0.019 \\
\hline 3/31/2017 & $12: 30$ & 1.52 & 1.17 & 0.348 & 0.549 & 0.501 & 0.849 & 0.766 & 0.754 & 3.18 & 6.40 & 0.203 \\
\hline 4/2/2017 & 09:45 & 1.40 & 1.17 & 0.228 & 0.549 & 0.501 & 0.729 & 0.646 & 0.663 & 2.35 & 6.00 & 0.141 \\
\hline $4 / 30 / 2017$ & 12:00 & 1.31 & 1.17 & 0.138 & 0.549 & 0.501 & 0.639 & 0.556 & 0.526 & 1.36 & 6.20 & 0.084 \\
\hline 7/1/2017 & 15:00 & 1.19 & 1.17 & 0.018 & 0.549 & 0.501 & 0.519 & 0.173 & 0.391 & 0.172 & 6.80 & 0.012 \\
\hline 8/26/2017 & $16: 30$ & 1.10 & 1.17 & -0.072 & 0.549 & 0.501 & 0.429 & 0.083 & 0.356 & 0.089 & 9.80 & 0.009 \\
\hline
\end{tabular}

$\mathrm{G}$ is the value on the staff gage corresponding to stream elevation; $\mathrm{y}_{\mathrm{G}}$ is the datum for stage at the staff gage; $\mathrm{H}_{\text {staff }}$ is the stage at the staff gage; $\mathrm{D}$ is the maximum depth of the stream profile; $\mathrm{OFF}_{\text {staff }}$ is the adjustment from staff gage datum to the maximum depth of the stream; $\mathrm{OFF}_{\text {logger }}$ is the adjustment due to logger position within the well point; Hstream is the total stage 
Table C2: QSWT Adjusted Stage and Discharge

\begin{tabular}{|c|c|c|c|c|c|c|c|c|c|c|c|c|}
\hline Date & Time & G & $\mathbf{y}_{\mathbf{G}}$ & $\begin{array}{c}\mathbf{H}_{\text {staff }} \\
(\mathbf{m})\end{array}$ & $\begin{array}{l}\text { D from } \\
12 / 3 / 2016 \\
\text { (m) }\end{array}$ & $\begin{array}{c}\text { OFF }_{\text {staff }} \\
\text { (m) }\end{array}$ & $\begin{array}{c}\mathbf{H}_{\text {stream }} \\
\text { with } \\
\text { OFF }_{\text {staff }} \\
\text { (m) }\end{array}$ & $\begin{array}{l}\text { Hstream } \\
\text { with } \\
\text { OFF staff } \\
\text { and } \\
\text { OFF } \\
\text { (m) }\end{array}$ & $\begin{array}{c}\text { Hstream with }_{\text {OFF }} \\
\text { OFaff, } \\
\text { OFF logger, } \\
\text { and final } \\
\text { manual } \\
\text { offset (m) }\end{array}$ & $\begin{array}{c}\text { Average } \\
\text { Discharge } \\
\left(\mathbf{m}^{3} / \mathbf{s}\right)\end{array}$ & $\begin{array}{l}\text { Average } \\
\% \text { Error }\end{array}$ & $\begin{array}{c}\text { Average } \\
\text { Error } \\
\text { (m) }\end{array}$ \\
\hline 10/9/2016 & $12: 30$ & 2.60 & 2.31 & 0.293 & 0.399 & 0.106 & 0.399 & 0.337 & & 0.240 & 3.50 & 0.008 \\
\hline $12 / 3 / 2016$ & 9:00 & 2.60 & 2.31 & 0.293 & 0.399 & 0.106 & 0.399 & 0.337 & & 0.244 & 5.47 & 0.013 \\
\hline $2 / 18 / 2017$ & 8:30 & 2.50 & 2.31 & 0.193 & 0.399 & 0.106 & 0.299 & 0.237 & 0.224 & 0.335 & 5.93 & 0.020 \\
\hline 3/31/2017 & $18: 15$ & 2.60 & 2.31 & 0.293 & 0.399 & 0.106 & 0.399 & 0.337 & 0.314 & 0.454 & 3.30 & 0.015 \\
\hline $4 / 1 / 2017$ & $10: 50$ & 2.61 & 2.31 & 0.303 & 0.399 & 0.106 & 0.409 & 0.219 & 0.232 & 0.472 & 2.70 & 0.013 \\
\hline 4/28/2017 & $15: 00$ & 2.65 & 2.31 & 0.343 & 0.399 & 0.106 & 0.449 & 0.259 & 0.313 & 0.642 & 2.10 & 0.013 \\
\hline 6/30/2017 & $15: 00$ & 2.53 & 2.31 & 0.223 & 0.399 & 0.106 & 0.329 & 0.139 & 0.183 & 0.169 & 2.65 & 0.004 \\
\hline 8/26/2017 & $9: 30$ & 2.53 & 2.31 & 0.223 & 0.399 & 0.106 & 0.329 & 0.139 & 0.190 & 0.100 & 2.40 & 0.002 \\
\hline
\end{tabular}

$\mathrm{G}$ is the value on the staff gage corresponding to stream elevation; $\mathrm{y}_{\mathrm{G}}$ is the datum for stage at the staff gage; $\mathrm{H}_{\text {staff }}$ is the stage at the staff gage; $\mathrm{D}$ is the

maximum depth of the stream profile; $\mathrm{OFF}_{\text {staff }}$ is the adjustment from staff gage datum to the maximum depth of the stream; $\mathrm{OFF}_{\text {logger }}$ is the adjustment due to logger position within the well point; Hstream is the total stage 
Table C3: QSEC Adjusted Stage and Discharge

\begin{tabular}{|c|c|c|c|c|c|c|c|c|c|c|c|c|}
\hline Date & Time & $\mathbf{G}$ & $\mathbf{y G}_{\mathbf{G}}$ & $\begin{array}{c}\text { Hstaff } \\
\text { (m) }\end{array}$ & $\begin{array}{l}\text { D from } \\
\text { 12/3/2016 } \\
\text { (m) }\end{array}$ & $\begin{array}{c}\text { OFF }_{\text {staff }} \\
\text { (m) }\end{array}$ & $\begin{array}{l}\text { Hstream } \\
\text { with } \\
\text { OFFstaff } \\
\text { (m) }\end{array}$ & $\begin{array}{l}\text { Hstream } \\
\text { with } \\
\text { OFFstaff } \\
\text { and } \\
\text { OFFlogger } \\
\text { (m) }\end{array}$ & $\begin{array}{c}\text { Hstream } \\
\text { with } \\
\text { OFFstaff, } \\
\text { OFFlogger, } \\
\text { and final } \\
\text { manual } \\
\text { offset (m) }\end{array}$ & $\begin{array}{c}\text { Average } \\
\text { Discharge } \\
\left(\mathrm{m}^{3} / \mathrm{s}\right)\end{array}$ & $\begin{array}{c}\text { Average } \\
\% \\
\text { Error }\end{array}$ & $\begin{array}{c}\text { Average } \\
\text { Error } \\
\text { (m) }\end{array}$ \\
\hline 10/9/2016 & $13: 10$ & 1.28 & 1.12 & 0.156 & 0.399 & 0.224 & 0.379 & 0.747 & & 0.275 & 5.53 & 0.015 \\
\hline $12 / 3 / 2016$ & $11: 00$ & 1.30 & 1.12 & 0.176 & 0.399 & 0.224 & 0.399 & 0.767 & & 0.354 & 2.97 & 0.010 \\
\hline 2/18/2017 & $12: 30$ & 1.32 & 1.12 & 0.196 & 0.399 & 0.224 & 0.419 & 0.787 & 0.515 & 0.372 & 3.87 & 0.014 \\
\hline 3/31/2017 & $17: 00$ & 1.63 & 1.12 & 0.506 & 0.399 & 0.224 & 0.729 & 1.10 & 0.893 & 2.15 & 2.20 & 0.047 \\
\hline $4 / 1 / 2017$ & $12: 00$ & 1.58 & 1.12 & 0.456 & 0.399 & 0.224 & 0.679 & 1.05 & 0.857 & 1.91 & 2.65 & 0.051 \\
\hline 4/28/2017 & $17: 00$ & 1.50 & 1.12 & 0.376 & 0.399 & 0.224 & 0.599 & 0.967 & 0.763 & 1.25 & 2.17 & 0.027 \\
\hline 6/30/2017 & $17: 00$ & 1.32 & 1.12 & 0.196 & 0.399 & 0.224 & 0.419 & 0.533 & 0.493 & 0.295 & 3.45 & 0.010 \\
\hline 8/26/2017 & $12: 00$ & 1.28 & 1.12 & 0.156 & 0.399 & 0.224 & 0.379 & 0.493 & 0.446 & 0.181 & 4.30 & 0.008 \\
\hline
\end{tabular}

$\mathrm{G}$ is the value on the staff gage corresponding to stream elevation; $\mathrm{y}_{\mathrm{G}}$ is the datum for stage at the staff gage; $\mathrm{H}_{\text {staff }}$ is the stage at the staff gage; $\mathrm{D}$ is the maximum depth of the stream profile; $\mathrm{OFF}_{\text {staff }}$ is the adjustment from staff gage datum to the maximum depth of the stream; OFF logger is the adjustment due to logger position within the well point; Hstream is the total stage

The bolded sample had a $\mathrm{G}$ recorded as 2.32, but based on previous $\mathrm{G}$ measurements, was determined to be a recorded error and should be 1.32 . 
Table C4: QHAN Adjusted Stage and Discharge

\begin{tabular}{|c|c|c|c|c|c|c|c|c|c|c|c|c|}
\hline Date & Time & G & $\mathbf{y G}_{\mathbf{G}}$ & $\begin{array}{c}\mathbf{H}_{\text {staff }} \\
(\mathrm{m})\end{array}$ & $\begin{array}{l}\text { D from } \\
12 / 4 / 2016 \\
\text { (m) }\end{array}$ & $\begin{array}{c}\text { OFF }_{\text {staff }} \\
\text { (m) }\end{array}$ & $\begin{array}{c}\mathbf{H}_{\text {stream }} \\
\text { with } \\
\text { OFF }_{\text {staff }} \\
\text { (m) }\end{array}$ & $\begin{array}{l}\text { Hstream } \\
\text { with } \\
\text { OFF staff } \\
\text { and } \\
\text { OFF logger } \\
\text { (m) }\end{array}$ & $\begin{array}{c}\mathrm{H}_{\text {stream }} \\
\text { with } \\
\text { OFF }_{\text {staff, }} \\
\text { OFF }_{\text {logger, }} \\
\text { and final } \\
\text { manual } \\
\text { offset (m) }\end{array}$ & $\begin{array}{c}\text { Average } \\
\text { Discharge } \\
\left(\mathrm{m}^{3} / \mathrm{s}\right)\end{array}$ & $\begin{array}{l}\text { Average } \\
\text { \% Error }\end{array}$ & $\begin{array}{c}\text { Average } \\
\text { Error } \\
\text { (m) }\end{array}$ \\
\hline 10/8/2016 & $13: 00$ & 2.46 & 2.21 & 0.253 & 0.311 & 0.189 & 0.441 & 0.851 & & 0.129 & 3.33 & 0.004 \\
\hline $12 / 4 / 2016$ & $8: 45$ & 2.33 & 2.21 & 0.122 & 0.311 & 0.189 & 0.311 & 0.721 & 0.259 & 0.036 & 7.53 & 0.003 \\
\hline 2/19/2017 & 8:00 & 2.36 & 2.21 & 0.152 & 0.311 & 0.189 & 0.341 & 0.751 & 0.310 & 0.058 & 6.93 & 0.004 \\
\hline 3/31/2017 & $14: 30$ & 2.95 & 2.21 & 0.743 & 0.311 & 0.189 & 0.931 & 1.34 & 0.263 & 2.06 & 2.60 & 0.053 \\
\hline 4/1/2017 & $14: 30$ & 2.60 & 2.21 & 0.393 & 0.311 & 0.189 & 0.581 & 0.991 & 1.14 & 0.525 & 4.50 & 0.024 \\
\hline 4/30/2017 & 8:30 & 2.43 & 2.21 & 0.223 & 0.311 & 0.189 & 0.411 & 0.381 & 0.389 & 0.124 & 5.23 & 0.007 \\
\hline 7/1/2017 & $11: 20$ & 2.30 & 2.21 & 0.091 & 0.311 & 0.189 & 0.280 & 0.250 & 0.295 & 0.016 & 13.2 & 0.002 \\
\hline 8/26/2017 & $15: 30$ & 2.27 & 2.21 & 0.061 & 0.311 & 0.189 & 0.250 & 0.220 & 0.258 & 0.007 & 4.20 & 0.000 \\
\hline
\end{tabular}

$\mathrm{G}$ is the value on the staff gage corresponding to stream elevation; $\mathrm{y}_{\mathrm{G}}$ is the datum for stage at the staff gage; $\mathrm{H}_{\text {staff }}$ is the stage at the staff gage; $\mathrm{D}$ is the

maximum depth of the stream profile; $\mathrm{OFF}_{\text {staff }}$ is the adjustment from staff gage datum to the maximum depth of the stream; OFF logger is the adjustment due to logger position within the well point; Hstream is the total stage 
Table C5: QIND Stage and Discharge

\begin{tabular}{ccccccccc} 
Date & Time & G & yg & $\begin{array}{c}\text { Hstaff } \\
\mathbf{( m )}\end{array}$ & $\begin{array}{c}\text { Average } \\
\text { Discharge } \\
\mathbf{( \mathbf { m } ^ { 3 } / \mathbf { s } )}\end{array}$ & $\begin{array}{c}\text { Average } \\
\text { \% Error }\end{array}$ & $\begin{array}{c}\text { Average } \\
\text { Error } \\
(\mathbf{m})\end{array}$ \\
\hline \hline $10 / 8 / 2016$ & $10: 00$ & 1.48 & 0.744 & 0.737 & 0.915 & 3.60 & 0.033 \\
$12 / 3 / 2016$ & $14: 15$ & 1.50 & 0.744 & 0.757 & 1.07 & 2.90 & 0.031 \\
$2 / 18 / 2017$ & $17: 00$ & 1.50 & 0.744 & 0.757 & 1.03 & 3.17 & 0.033 \\
$4 / 2 / 2017$ & $12: 15$ & 1.76 & 0.744 & 1.02 & 5.21 & 2.25 & 0.117 \\
$\mathbf{4 / 2 9 / 2 0 1 7}$ & $\mathbf{1 5 : 1 5}$ & $\mathbf{2 . 6 4}$ & $\mathbf{0 . 7 4 4}$ & $\mathbf{1 . 9 0}$ & $\mathbf{3 . 0 0}$ & $\mathbf{2 . 3 5}$ & $\mathbf{0 . 0 7 0}$ \\
$7 / 1 / 2017$ & $8: 30$ & 1.43 & 0.744 & 0.687 & 0.433 & 3.50 & 0.015 \\
$8 / 26 / 2017$ & $14: 00$ & 1.40 & 0.744 & 0.657 & 0.255 & 3.90 & 0.010 \\
\hline \hline
\end{tabular}

$\mathrm{H}_{\text {stream }}$ was not calculated; $\mathrm{H}_{\text {staff }}$ was used for stage-discharge rating curves. Bolded sample stage-discharge relationship was an outlier and was removed. 


\section{APPENDIX D}

TABULATED CHEMICAL AND METER DATA 
Table D1: Tabulated Cation and Anion Data

\begin{tabular}{|c|c|c|c|c|c|c|c|c|c|c|c|}
\hline $\begin{array}{c}\text { LOC } \\
\text { CODE }\end{array}$ & Date & $\begin{array}{r}\text { B } \\
(\mathrm{mg} / \mathrm{L})\end{array}$ & $\begin{array}{r}\mathrm{Ca} \\
(\mathrm{mg} / \mathrm{L})\end{array}$ & $\begin{array}{r}\mathrm{Mg} \\
(\mathrm{mg} / \mathrm{L})\end{array}$ & $\begin{array}{r}\mathrm{Na} \\
(\mathrm{mg} / \mathrm{L})\end{array}$ & $\begin{array}{r}\mathbf{L i} \\
(\mathrm{mg} / \mathrm{L})\end{array}$ & $\begin{array}{r}\mathrm{K} \\
(\mathrm{mg} / \mathrm{L})\end{array}$ & $\begin{array}{r}\mathrm{Sr} \\
(\mathrm{mg} / \mathrm{L})\end{array}$ & $\begin{array}{r}\mathrm{Cl} \\
(\mathrm{mg} / \mathrm{L})\end{array}$ & $\begin{array}{r}\mathrm{NO}_{3} \\
(\mathrm{mg} / \mathrm{L})\end{array}$ & $\begin{array}{r}\mathrm{SO}_{4} \\
(\mathrm{mg} / \mathrm{L})\end{array}$ \\
\hline ZEN & $3 / 20 / 16$ & 0.009 & 48.3 & 26.0 & $<0.72$ & $<0.001$ & 1.20 & 0.527 & 1.83 & 3.65 & 7.44 \\
\hline DROPL & $3 / 20 / 16$ & 0.008 & 25.0 & 10.3 & 0.86 & $<0.001$ & 0.752 & 0.035 & 2.63 & 4.10 & 4.60 \\
\hline MEFF & $3 / 20 / 16$ & 0.008 & 30.9 & 4.44 & 1.12 & $<0.001$ & 0.613 & 0.056 & 2.77 & 3.55 & 5.73 \\
\hline CRABT & 3/20/16 & 0.006 & 32.7 & 8.72 & 1.02 & $<0.001$ & 0.918 & 0.076 & 2.83 & 0.890 & 7.66 \\
\hline OLDU & $3 / 21 / 16$ & 0.008 & 47.0 & 1.95 & 2.60 & 0.002 & 0.559 & 0.148 & 11.4 & 0.795 & 5.20 \\
\hline OLDSWT & $3 / 21 / 16$ & 0.105 & 299 & 53.4 & 19.3 & 0.391 & 23.0 & 4.03 & 27.9 & 0.756 & 406 \\
\hline $\mathrm{ECH}$ & $3 / 21 / 16$ & 0.004 & 25.5 & 1.27 & 0.85 & 0.001 & 0.368 & 0.100 & 1.99 & 1.50 & 4.51 \\
\hline GMILL & $3 / 21 / 16$ & 0.005 & 19.5 & 1.02 & 0.82 & $<0.001$ & 0.467 & 0.068 & 1.15 & 2.45 & 7.35 \\
\hline LUGER & $3 / 21 / 16$ & 0.005 & 18.3 & 1.01 & 0.82 & $<0.001$ & 0.431 & 0.067 & 0.995 & 2.02 & 7.91 \\
\hline CBRN & $3 / 22 / 16$ & 0.006 & 36.7 & 4.98 & 0.86 & $<0.001$ & 0.691 & 0.059 & & & \\
\hline HANCK & $3 / 22 / 16$ & 0.005 & 42.2 & 2.26 & 1.36 & 0.001 & 0.432 & 0.153 & 2.27 & 3.88 & 7.11 \\
\hline BROY & $3 / 22 / 16$ & 0.005 & 47.8 & 1.91 & 1.17 & $<0.001$ & 0.517 & 0.156 & 2.07 & 2.26 & 9.65 \\
\hline НАТСН & $3 / 22 / 16$ & 0.005 & 33.7 & 3.68 & 0.88 & $<0.001$ & 0.659 & 0.064 & 2.45 & 3.74 & 6.93 \\
\hline OLSON & $3 / 22 / 16$ & 0.006 & 17.8 & 1.89 & 1.12 & 0.001 & 0.619 & 0.070 & 1.47 & 1.58 & 9.02 \\
\hline QIND & $10 / 8 / 16$ & 0.004 & 0.0 & 0.08 & 0.72 & 0.001 & 0.080 & 0.001 & 3.81 & 0.657 & 6.68 \\
\hline QSEC & $10 / 9 / 16$ & 0.012 & 39.6 & 9.09 & 2.63 & 0.001 & 1.95 & 0.194 & 3.65 & 3.50 & 4.48 \\
\hline QSWT & $10 / 9 / 16$ & 0.008 & 38.6 & 7.36 & 1.81 & 0.001 & 1.90 & 0.115 & 4.58 & 3.31 & 11.6 \\
\hline QRCH & $10 / 8 / 16$ & 0.014 & 59.9 & 11.1 & 2.54 & 0.009 & 2.62 & 0.199 & 7.88 & 3.23 & 14.4 \\
\hline
\end{tabular}




\begin{tabular}{|c|c|c|c|c|c|c|c|c|c|c|c|}
\hline $\begin{array}{l}\text { LOC } \\
\text { CODE }\end{array}$ & Date & $\begin{array}{r}B \\
(\mathrm{mg} / \mathrm{L})\end{array}$ & $\begin{array}{r}\mathrm{Ca} \\
(\mathrm{mg} / \mathrm{L})\end{array}$ & $\begin{array}{r}\mathrm{Mg} \\
(\mathrm{mg} / \mathrm{L})\end{array}$ & $\begin{array}{r}\mathrm{Na} \\
(\mathrm{mg} / \mathrm{L})\end{array}$ & $\begin{array}{r}\mathbf{L i} \\
(\mathrm{mg} / \mathrm{L})\end{array}$ & $\begin{array}{r}K \\
(\mathrm{mg} / \mathrm{L})\end{array}$ & $\begin{array}{r}\mathrm{Sr} \\
(\mathrm{mg} / \mathrm{L})\end{array}$ & $\begin{array}{r}\mathrm{Cl} \\
(\mathrm{mg} / \mathrm{L})\end{array}$ & $\begin{array}{r}\mathrm{NO}_{3} \\
(\mathrm{mg} / \mathrm{L})\end{array}$ & $\begin{array}{r}\mathrm{SO}_{4} \\
(\mathrm{mg} / \mathrm{L})\end{array}$ \\
\hline QHAN & $10 / 8 / 16$ & 0.018 & 38.9 & 7.00 & 3.95 & 0.001 & 4.70 & 0.181 & 8.22 & 2.10 & 11.7 \\
\hline GMILL & $12 / 2 / 16$ & 0.098 & 21.3 & 1.37 & 6.54 & 0.002 & 0.429 & 0.096 & 0.930 & 3.96 & 5.43 \\
\hline OLDSWT & $12 / 2 / 16$ & 0.101 & 286 & 54.9 & 20.3 & 0.220 & 23.6 & 3.87 & 28.2 & 0.244 & 365 \\
\hline QSWT & $12 / 2 / 16$ & 0.008 & 53.8 & 9.69 & 2.22 & 0.007 & 2.08 & 0.175 & 3.61 & 3.81 & 12.9 \\
\hline QSEC & $12 / 3 / 16$ & 0.006 & 38.7 & 6.38 & 1.60 & 0.001 & 1.26 & 0.098 & 3.38 & 5.39 & 6.01 \\
\hline ZEN & $12 / 3 / 16$ & 0.007 & 51.1 & 28.9 & $<0.72$ & 0.002 & 0.997 & 1.17 & 1.21 & 2.34 & 11.5 \\
\hline QIND & $12 / 3 / 16$ & 0.006 & 36.2 & 6.31 & 2.50 & 0.001 & 1.09 & 0.166 & 3.13 & 3.30 & 7.82 \\
\hline OLSON & $12 / 3 / 16$ & 0.009 & 15.9 & 1.66 & 1.03 & 0.001 & 0.745 & 0.064 & 1.23 & 5.56 & 10.2 \\
\hline QHAN & $12 / 4 / 16$ & 0.032 & 54.8 & 10.6 & 7.28 & 0.001 & 2.49 & 0.338 & 10.6 & 2.99 & 25.7 \\
\hline CRABT & $12 / 4 / 16$ & 0.009 & 41.3 & 9.24 & 1.25 & $<0.001$ & 1.00 & 0.107 & 2.02 & 0.897 & 8.58 \\
\hline QRCH & $12 / 4 / 16$ & 0.012 & 42.1 & 6.12 & 2.87 & 0.001 & 1.75 & 0.165 & 4.53 & 4.28 & 14.0 \\
\hline OLDSWT & $12 / 2 / 16$ & 0.121 & 288 & 54.5 & 20.5 & 0.216 & 23.6 & 3.82 & 26.4 & 0.219 & 347 \\
\hline GMILL & 2/18/17 & 0.005 & 25.1 & 1.33 & 2.13 & 0.001 & 0.536 & 0.110 & 1.24 & 2.40 & 5.05 \\
\hline OLDSWT & 2/18/17 & 0.114 & $>200$ & $>36$ & 19.9 & $<0.001$ & 24.6 & $>1.4$ & 7.13 & 0.226 & 402 \\
\hline OLDSWT & 2/18/17 & 0.110 & 70 & 53.4 & 18.3 & 0.227 & 23.0 & 5.55 & 7.13 & 0.226 & 402 \\
\hline OLDSWT & 2/18/17 & 0.115 & 70 & 53.0 & 18.6 & 0.252 & 22.8 & 5.45 & 6.75 & $<0.034$ & 409 \\
\hline QSWT & 2/18/17 & 0.011 & 66.1 & 12.1 & 4.71 & 0.011 & 1.87 & 0.289 & 4.72 & 2.18 & 17.3 \\
\hline OLSON & 2/18/17 & 0.015 & 21.8 & 2.08 & 3.36 & 0.002 & 0.511 & 0.108 & 0.725 & 1.58 & 8.95 \\
\hline QIND & 2/18/17 & 0.014 & 36.9 & 7.32 & 5.60 & 0.001 & 0.764 & 0.213 & 4.07 & 1.82 & 9.69 \\
\hline
\end{tabular}




\begin{tabular}{|c|c|c|c|c|c|c|c|c|c|c|c|}
\hline $\begin{array}{l}\text { LOC } \\
\text { CODE }\end{array}$ & Date & $\begin{array}{r}B \\
(\mathrm{mg} / \mathrm{L})\end{array}$ & $\begin{array}{r}\mathrm{Ca} \\
(\mathrm{mg} / \mathrm{L})\end{array}$ & $\begin{array}{r}\mathrm{Mg} \\
(\mathrm{mg} / \mathrm{L})\end{array}$ & $\begin{array}{r}\mathrm{Na} \\
(\mathrm{mg} / \mathrm{L})\end{array}$ & $\begin{array}{r}\mathbf{L i} \\
(\mathrm{mg} / \mathrm{L})\end{array}$ & $\begin{array}{r}K \\
(\mathrm{mg} / \mathrm{L})\end{array}$ & $\begin{array}{r}\mathrm{Sr} \\
(\mathrm{mg} / \mathrm{L})\end{array}$ & $\begin{array}{r}\mathrm{Cl} \\
(\mathrm{mg} / \mathrm{L})\end{array}$ & $\begin{array}{r}\mathrm{NO}_{3} \\
(\mathrm{mg} / \mathrm{L})\end{array}$ & $\begin{array}{r}\mathrm{SO}_{4} \\
(\mathrm{mg} / \mathrm{L})\end{array}$ \\
\hline QSEC & 2/18/17 & 0.007 & 37.7 & 7.08 & 2.96 & 0.001 & 0.949 & 0.099 & 3.35 & 5.49 & 4.36 \\
\hline ZEN & 2/18/17 & 0.006 & 56.4 & 27.9 & 1.17 & 0.002 & 1.17 & 1.12 & 0.883 & 3.41 & 8.92 \\
\hline CRABT & 2/19/17 & 0.006 & 39.6 & 9.71 & 2.16 & $<0.001$ & 0.901 & 0.113 & 1.01 & 0.683 & 7.12 \\
\hline QHAN & 2/19/17 & 0.010 & 47.4 & 9.71 & 9.72 & 0.001 & 1.52 & 0.271 & 8.01 & 1.59 & 13.0 \\
\hline QRCH & 2/19/17 & 0.010 & 47.2 & 8.07 & 6.44 & 0.001 & 1.23 & 0.233 & 5.90 & 2.39 & 13.8 \\
\hline CRABT & 3/9/17 & 0.014 & 40.2 & 10.7 & 3.06 & $<0.001$ & 0.769 & 0.110 & 1.16 & 0.633 & 7.25 \\
\hline DROPL & $3 / 10 / 17$ & 0.005 & 25.8 & 9.68 & 1.55 & 0.001 & 0.659 & 0.044 & 1.54 & 3.87 & 3.58 \\
\hline MEFF & 3/11/17 & 0.008 & 33.2 & 4.17 & 2.27 & $<0.001$ & 0.498 & 0.074 & 2.00 & 3.63 & 5.10 \\
\hline ZEN & $3 / 10 / 17$ & 0.009 & 55.6 & 28.6 & 1.12 & 0.001 & 1.08 & 0.991 & 0.728 & 3.72 & 8.17 \\
\hline ECH & 3/10/17 & 0.006 & 31.5 & 1.38 & 1.86 & 0.003 & 0.475 & 0.138 & 0.591 & 1.18 & 3.62 \\
\hline GMILL & $3 / 10 / 17$ & 0.013 & 21.3 & 1.16 & 2.31 & 0.001 & 0.344 & 0.095 & 0.765 & 2.63 & 5.21 \\
\hline LUGER & $3 / 10 / 17$ & 0.012 & 19.3 & 1.03 & 2.07 & 0.001 & 0.251 & 0.091 & 0.890 & 2.30 & 5.90 \\
\hline OLDSWT & $3 / 10 / 17$ & 0.110 & 69 & 52.3 & 18.0 & 0.227 & 22.9 & 5.39 & 8.79 & 0.114 & 401 \\
\hline OLDU & $3 / 10 / 17$ & 0.015 & 46.9 & 1.74 & 4.77 & 0.003 & 0.387 & 0.196 & 11.7 & 0.386 & 5.34 \\
\hline OLDU & $3 / 10 / 17$ & 0.004 & 49.0 & 2.04 & 2.87 & 0.003 & 0.512 & 0.153 & 11.4 & 0.379 & 4.19 \\
\hline OLDU & $3 / 10 / 17$ & 0.004 & 46.5 & 1.75 & 4.63 & 0.003 & 0.359 & 0.196 & 11.4 & 0.379 & 4.19 \\
\hline BROY & 3/11/17 & 0.010 & 46.6 & 1.76 & 2.31 & 0.001 & 0.339 & 0.206 & 1.95 & 2.04 & 10.5 \\
\hline CBRN & 3/9/17 & 0.008 & 41.8 & 5.20 & 1.85 & 0.001 & 0.656 & 0.076 & 1.53 & 4.58 & 6.91 \\
\hline HANCK & 3/9/17 & 0.008 & 45.5 & 2.17 & 2.91 & 0.003 & 0.459 & 0.201 & 1.50 & 3.59 & 7.41 \\
\hline
\end{tabular}




\begin{tabular}{|c|c|c|c|c|c|c|c|c|c|c|c|}
\hline $\begin{array}{c}\text { LOC } \\
\text { CODE }\end{array}$ & Date & $\begin{array}{r}B \\
(\mathrm{mg} / \mathrm{L})\end{array}$ & $\begin{array}{r}\text { Ca } \\
(\mathrm{mg} / \mathrm{L})\end{array}$ & $\begin{array}{r}\text { Mg } \\
(\mathrm{mg} / \mathrm{L})\end{array}$ & $\begin{array}{r}\mathrm{Na} \\
(\mathrm{mg} / \mathrm{L})\end{array}$ & $\begin{array}{r}\mathbf{L i} \\
(\mathrm{mg} / \mathrm{L})\end{array}$ & $\begin{array}{r}\mathrm{K} \\
(\mathrm{mg} / \mathrm{L})\end{array}$ & $\begin{array}{r}\mathrm{Sr} \\
(\mathrm{mg} / \mathrm{L})\end{array}$ & $\begin{array}{r}\mathrm{Cl} \\
(\mathrm{mg} / \mathrm{L})\end{array}$ & $\begin{array}{r}\mathrm{NO}_{3} \\
(\mathrm{mg} / \mathrm{L})\end{array}$ & $\begin{array}{r}\mathrm{SO}_{4} \\
(\mathrm{mg} / \mathrm{L})\end{array}$ \\
\hline НАТСН & $3 / 9 / 17$ & 0.007 & 34.9 & 3.40 & 1.76 & 0.001 & 0.505 & 0.083 & 1.59 & 3.70 & 7.46 \\
\hline OLSON & 3/11/17 & 0.010 & 17.4 & 1.74 & 2.17 & 0.002 & 0.529 & 0.085 & 0.851 & 2.34 & 8.90 \\
\hline QSWT & 3/31/17 & 0.010 & 43.0 & 7.50 & 3.89 & 0.005 & 1.45 & 0.169 & 3.94 & 2.21 & 9.59 \\
\hline QIND & $4 / 2 / 17$ & 0.009 & 34.3 & 5.52 & 4.11 & 0.001 & 0.994 & 0.140 & 2.93 & 2.79 & 7.96 \\
\hline QSEC & $3 / 31 / 17$ & 0.011 & 35.7 & 4.51 & 3.79 & $<0.001$ & 1.43 & 0.084 & 3.99 & 3.84 & 4.19 \\
\hline QHAN & $3 / 31 / 17$ & 0.025 & 17.2 & 3.53 & 6.43 & $<0.001$ & 1.86 & 0.096 & 5.13 & 1.12 & 8.08 \\
\hline QRCH & $3 / 31 / 17$ & 0.022 & 30.3 & 6.13 & 8.59 & 0.001 & 2.79 & 0.162 & 7.33 & 2.27 & 12.2 \\
\hline QSWT & $4 / 1 / 17$ & 0.016 & 39.8 & 7.06 & 7.22 & 0.004 & 1.05 & 0.155 & 3.55 & 2.39 & 9.13 \\
\hline QIND & $4 / 2 / 17$ & 0.008 & 31.5 & 5.80 & 2.28 & 0.001 & 1.07 & 0.108 & 2.84 & 2.79 & 7.60 \\
\hline QIND & $4 / 2 / 17$ & 0.009 & 31.8 & 5.38 & 3.88 & 0.001 & 0.884 & 0.138 & 2.84 & 2.79 & 7.60 \\
\hline QSEC & $4 / 1 / 17$ & 0.008 & 38.6 & 5.08 & 3.21 & 0.001 & 1.17 & 0.077 & 3.09 & 5.19 & 4.51 \\
\hline QHAN & $4 / 1 / 17$ & 0.020 & 24.3 & 4.85 & 7.54 & 0.001 & 1.38 & 0.107 & 4.97 & 1.45 & 9.56 \\
\hline QRCH & $4 / 2 / 17$ & 0.011 & 34.4 & 5.00 & 4.70 & 0.001 & 1.25 & 0.119 & 4.32 & 3.34 & 10.0 \\
\hline GMILL & 4/28/17 & 0.010 & 21.5 & 1.01 & 0.94 & 0.001 & 0.380 & 0.065 & 0.721 & 3.78 & 4.95 \\
\hline OLDSWT & $4 / 28 / 17$ & 0.089 & 230 & 41.7 & 15.0 & 0.168 & 17.4 & 2.83 & 6.73 & 0.206 & 291 \\
\hline QSWT & $4 / 28 / 17$ & 0.013 & 41.1 & 6.94 & 2.13 & 0.004 & 1.04 & 0.102 & 3.18 & 2.19 & 8.24 \\
\hline OLSON & 4/29/17 & 0.017 & 13.8 & 1.50 & 1.29 & 0.001 & 0.491 & 0.039 & 0.875 & 3.98 & 8.45 \\
\hline QIND & 4/29/17 & 0.007 & 31.7 & 6.22 & 1.65 & 0.001 & 0.856 & 0.094 & 2.26 & 1.99 & 6.67 \\
\hline QSEC & 4/28/17 & 0.007 & 30.8 & 5.04 & 1.33 & $<0.001$ & 0.835 & 0.050 & 2.58 & 4.48 & 4.08 \\
\hline ZEN & 4/29/17 & 0.010 & 51.5 & 27.6 & 0.77 & $<0.001$ & 0.875 & 0.314 & 0.702 & 3.76 & 5.50 \\
\hline
\end{tabular}




\begin{tabular}{|c|c|c|c|c|c|c|c|c|c|c|c|}
\hline $\begin{array}{l}\text { LOC } \\
\text { CODE }\end{array}$ & Date & $\begin{array}{r}B \\
(\mathrm{mg} / \mathrm{L})\end{array}$ & $\begin{array}{r}\mathrm{Ca} \\
(\mathrm{mg} / \mathrm{L})\end{array}$ & $\begin{array}{r}\mathrm{Mg} \\
(\mathrm{mg} / \mathrm{L})\end{array}$ & $\begin{array}{r}\mathrm{Na} \\
(\mathrm{mg} / \mathrm{L})\end{array}$ & $\begin{array}{r}\mathbf{L i} \\
(\mathrm{mg} / \mathrm{L})\end{array}$ & $\begin{array}{r}K \\
(\mathrm{mg} / \mathrm{L})\end{array}$ & $\begin{array}{r}\mathrm{Sr} \\
(\mathrm{mg} / \mathrm{L})\end{array}$ & $\begin{array}{r}\mathrm{Cl} \\
(\mathrm{mg} / \mathrm{L})\end{array}$ & $\begin{array}{r}\mathrm{NO}_{3} \\
(\mathrm{mg} / \mathrm{L})\end{array}$ & $\begin{array}{r}\mathrm{SO}_{4} \\
(\mathrm{mg} / \mathrm{L})\end{array}$ \\
\hline CRABT & 4/30/17 & 0.007 & 46.1 & 13.2 & 1.06 & $<0.001$ & 0.897 & 0.084 & 1.44 & 0.871 & 6.58 \\
\hline CRABT & 4/30/17 & 0.008 & 45.6 & 13.2 & 1.05 & $<0.001$ & 0.884 & 0.082 & 1.44 & 0.915 & 6.61 \\
\hline QHAN & 4/30/17 & 0.017 & 37.6 & 7.53 & 3.81 & 0.001 & 1.44 & 0.128 & 5.91 & 1.60 & 9.68 \\
\hline QRCH & 4/30/17 & 0.014 & 37.1 & 6.30 & 2.50 & 0.001 & 1.07 & 0.110 & 3.84 & 3.10 & 9.43 \\
\hline OLDSWT & $6 / 4 / 17$ & & & & & & & & 29.0 & 0.324 & 399 \\
\hline ZEN & $7 / 1 / 17$ & 0.012 & 50.7 & 26.7 & $<0.72$ & 0.001 & 0.984 & 0.772 & 0.930 & 3.04 & 8.54 \\
\hline GMILL & 6/30/17 & 0.008 & 26.0 & 1.35 & 1.10 & 0.001 & 0.375 & 0.085 & 4.17 & 2.28 & 4.56 \\
\hline OLDSWT & 6/30/17 & 0.111 & 307 & 52.8 & 18.1 & 0.220 & 22.72 & 3.72 & 10.4 & & 399 \\
\hline CRABT & 7/1/17 & & & & & & & & 1.52 & 1.15 & 6.26 \\
\hline OLSON & 7/1/17 & 0.010 & 26.1 & 2.40 & 1.54 & 0.002 & 0.443 & 0.093 & 0.763 & 0.862 & 8.43 \\
\hline QSWT & 6/30/17 & 0.011 & 67.8 & 12.7 & 2.38 & 0.011 & 1.96 & 0.213 & 4.41 & 2.07 & 18.2 \\
\hline QSEC & 6/30/17 & 0.007 & 37.0 & 7.88 & 1.54 & 0.001 & 1.04 & 0.079 & 3.18 & 5.23 & 3.89 \\
\hline QIND & $7 / 1 / 17$ & 0.008 & 43.5 & 9.83 & 1.77 & 0.001 & 1.01 & 0.147 & 2.19 & 1.88 & 5.97 \\
\hline QSWT & 6/30/17 & 0.011 & 68.4 & 12.9 & 2.45 & 0.012 & 1.94 & 0.222 & 3.94 & 2.00 & 17.7 \\
\hline QHAN & 7/1/17 & 0.019 & 60.9 & 12.7 & 4.40 & 0.002 & 2.15 & 0.272 & 6.08 & 1.53 & 9.59 \\
\hline QRCH & $7 / 1 / 17$ & 0.012 & 49.1 & 8.91 & 2.67 & 0.001 & 1.91 & 0.181 & 3.68 & 3.52 & 11.3 \\
\hline ZEN & $8 / 27 / 17$ & 0.008 & 52.5 & 27.9 & $<0.72$ & 0.001 & 0.998 & 0.992 & 1.47 & 3.62 & 9.97 \\
\hline ZEN & 8/27/17 & 0.007 & 68.7 & 28.0 & $<0.72$ & 0.002 & 1.02 & 1.06 & 1.51 & 3.52 & 9.86 \\
\hline GMILL & 8/26/17 & 0.005 & 26.6 & 1.57 & 1.28 & 0.002 & 0.429 & 0.094 & 0.661 & 2.36 & 4.88 \\
\hline
\end{tabular}




\begin{tabular}{|c|c|c|c|c|c|c|c|c|c|c|c|}
\hline $\begin{array}{l}\text { LOC } \\
\text { CODE }\end{array}$ & Date & $\begin{array}{r}B \\
(\mathrm{mg} / \mathrm{L})\end{array}$ & $\begin{array}{r}\mathrm{Ca} \\
(\mathrm{mg} / \mathrm{L})\end{array}$ & $\begin{array}{r}\mathrm{Mg} \\
(\mathrm{mg} / \mathrm{L})\end{array}$ & $\begin{array}{r}\mathrm{Na} \\
(\mathrm{mg} / \mathrm{L})\end{array}$ & $\begin{array}{r}\mathbf{L i} \\
(\mathrm{mg} / \mathrm{L})\end{array}$ & $\begin{array}{r}\mathrm{K} \\
(\mathrm{mg} / \mathrm{L})\end{array}$ & $\begin{array}{r}\mathrm{Sr} \\
(\mathrm{mg} / \mathrm{L})\end{array}$ & $\begin{array}{r}\mathrm{Cl} \\
(\mathrm{mg} / \mathrm{L})\end{array}$ & $\begin{array}{r}\mathrm{NO}_{3} \\
(\mathrm{mg} / \mathrm{L})\end{array}$ & $\begin{array}{r}\mathrm{SO}_{4} \\
(\mathrm{mg} / \mathrm{L})\end{array}$ \\
\hline OLDSWT & 8/26/17 & 0.108 & 304 & 53.9 & 18.0 & 0.226 & 22.8 & 3.83 & 30.3 & 0.246 & 404 \\
\hline CRABT & $8 / 27 / 17$ & 0.013 & 50.8 & 12.5 & 1.31 & $<0.001$ & 1.16 & 0.107 & 1.40 & 1.41 & 8.67 \\
\hline WVU & 8/27/17 & $<0.004$ & 0.1 & $<0.08$ & $<0.72$ & $<0.001$ & 0.657 & $<0.001$ & $<0.101$ & $<0.025$ & $<0.147$ \\
\hline QSWT & 8/26/17 & 0.013 & 76.7 & 16.6 & 2.53 & 0.015 & 2.67 & 0.274 & 4.90 & 2.27 & 23.9 \\
\hline QSEC & 8/26/17 & 0.007 & 41.9 & 8.67 & 1.35 & 0.001 & 0.969 & 0.106 & 2.91 & 3.80 & 3.87 \\
\hline QIND & 8/26/17 & 0.011 & 44.0 & 9.01 & 2.40 & 0.001 & 1.04 & 0.183 & 3.51 & 1.39 & 7.76 \\
\hline QHAN & 8/26/17 & 0.022 & 54.5 & 13.2 & 5.41 & 0.002 & 3.30 & 0.286 & 7.94 & 0.720 & 10.0 \\
\hline QRCH & 8/26/17 & 0.013 & 52.2 & 8.68 & 2.81 & 0.001 & 2.14 & 0.210 & 3.88 & 3.18 & 12.6 \\
\hline OLDSWT & $9 / 11 / 17$ & 0.107 & 302 & 53.3 & 18.0 & 0.221 & 22.8 & 3.81 & 30.3 & 0.229 & 403 \\
\hline OLDU & 9/11/17 & 0.005 & 48.2 & 1.77 & 2.46 & 0.003 & 0.364 & 0.135 & 10.3 & 0.376 & 3.71 \\
\hline QSWT & 9/11/17 & & & & & & & & & & \\
\hline $\mathrm{ECH}$ & 9/11/17 & 0.005 & 66.3 & 1.45 & 0.91 & 0.003 & 0.285 & 0.132 & 0.769 & 1.09 & 3.11 \\
\hline GMILL & 9/11/17 & 0.008 & 25.5 & 1.57 & 1.31 & 0.002 & 0.370 & 0.093 & 0.728 & 1.15 & 5.75 \\
\hline LUGER & 9/11/17 & 0.004 & 22.2 & 1.30 & 1.01 & 0.001 & 0.317 & 0.081 & 0.933 & 2.03 & 4.94 \\
\hline QRCH & $9 / 12 / 17$ & & & & & & & & & & \\
\hline CBRN & $9 / 12 / 17$ & 0.009 & 53.3 & 8.97 & 1.10 & 0.001 & 0.657 & 0.071 & 2.17 & 2.13 & 5.34 \\
\hline HANCK & $9 / 12 / 17$ & 0.007 & 42.1 & 2.08 & 1.31 & 0.002 & 0.269 & 0.128 & 1.14 & 5.88 & 5.58 \\
\hline ZEN & $9 / 12 / 17$ & 0.010 & 53.1 & 27.9 & $<0.72$ & 0.002 & 0.979 & 1.10 & 1.41 & 3.05 & 6.80 \\
\hline DROPL & 9/12/17 & 0.006 & 35.1 & 13.2 & 0.79 & 0.001 & 0.749 & 0.050 & 1.84 & 2.91 & 10.8 \\
\hline
\end{tabular}




\begin{tabular}{|c|c|c|c|c|c|c|c|c|c|c|c|}
\hline $\begin{array}{l}\text { LOC } \\
\text { CODE }\end{array}$ & Date & $\begin{array}{r}B \\
(\mathrm{mg} / \mathrm{L})\end{array}$ & $\begin{array}{r}\mathrm{Ca} \\
(\mathrm{mg} / \mathrm{L})\end{array}$ & $\begin{array}{r}\mathrm{Mg} \\
(\mathrm{mg} / \mathrm{L})\end{array}$ & $\begin{array}{r}\mathrm{Na} \\
(\mathrm{mg} / \mathrm{L})\end{array}$ & $\begin{array}{r}\mathbf{L i} \\
(\mathrm{mg} / \mathbf{L})\end{array}$ & $\begin{array}{r}K \\
(\mathrm{mg} / \mathrm{L})\end{array}$ & $\begin{array}{r}\mathrm{Sr} \\
(\mathrm{mg} / \mathrm{L})\end{array}$ & $\begin{array}{r}\mathrm{Cl} \\
(\mathrm{mg} / \mathrm{L})\end{array}$ & $\begin{array}{r}\mathrm{NO}_{3} \\
(\mathrm{mg} / \mathrm{L})\end{array}$ & $\begin{array}{r}\mathrm{SO}_{4} \\
(\mathrm{mg} / \mathrm{L})\end{array}$ \\
\hline MEFF & 9/12/17 & 0.008 & 46.3 & 5.63 & 1.27 & 0.001 & 0.550 & 0.069 & 2.24 & 4.05 & 4.33 \\
\hline BROY & 9/12/17 & 0.006 & 53.1 & 1.86 & 1.28 & 0.002 & 0.408 & 0.154 & 1.45 & 2.43 & 5.88 \\
\hline НАТСН & 9/12/17 & 0.008 & 50.2 & 5.25 & 1.10 & 0.001 & 0.624 & 0.087 & 1.76 & 3.94 & 5.05 \\
\hline OLSON & 9/12/17 & 0.006 & 26.6 & 2.47 & 1.50 & 0.002 & 0.462 & 0.095 & 0.845 & 0.799 & 8.61 \\
\hline OLSON & $9 / 12 / 17$ & 0.005 & 26.8 & 2.48 & 1.49 & 0.002 & 0.480 & 0.095 & 0.859 & 0.793 & 8.86 \\
\hline WVU & 9/12/17 & $<0.004$ & 0.2 & $<0.08$ & $<0.72$ & $<0.001$ & $<0.08$ & $<0.001$ & $<0.101$ & $<0.025$ & $<0.147$ \\
\hline OLSON & $12 / 17 / 17$ & 0.004 & 25.7 & 2.15 & 1.48 & 0.003 & 0.454 & 0.101 & 0.689 & 0.877 & 0.877 \\
\hline QHAN & 12/17/17 & 0.011 & 55.5 & 12.1 & 5.21 & 0.002 & 1.482 & 0.299 & 7.15 & 1.92 & 1.92 \\
\hline ZEN & $12 / 17 / 17$ & 0.004 & 52.0 & 28.0 & $<0.72$ & 0.002 & 0.975 & 1.00 & 0.724 & 3.26 & 3.26 \\
\hline ZEN & $12 / 17 / 17$ & 0.011 & 54.6 & 28.2 & 2.10 & 0.002 & 0.975 & 0.995 & 0.745 & 3.24 & 3.24 \\
\hline GMILL & 12/18/17 & 0.005 & 24.6 & 1.28 & 1.28 & 0.002 & 0.410 & 0.090 & 0.571 & 2.13 & 2.13 \\
\hline OLDSWT & $12 / 18 / 17$ & 0.103 & 293 & 54.7 & 19.34 & 0.226 & 21.497 & 3.80 & 28.6 & 0.190 & 0.190 \\
\hline QSWT & $12 / 18 / 17$ & 0.012 & 74.9 & 17.1 & 2.50 & 0.016 & 2.327 & 0.285 & 4.21 & 2.40 & 2.40 \\
\hline QSEC & 12/18/17 & 0.007 & 39.0 & 8.06 & 1.45 & 0.001 & 0.833 & 0.107 & 2.43 & 4.90 & 4.90 \\
\hline QIND & 12/19/17 & 0.005 & 43.5 & 8.52 & 2.45 & 0.001 & 0.883 & 0.200 & 3.17 & 1.58 & 1.58 \\
\hline CRABT & 12/19/17 & 0.006 & 50.9 & 17.2 & 1.16 & $<0.001$ & 0.975 & 0.097 & 1.50 & 3.17 & 3.17 \\
\hline QRCH & 12/19/17 & 0.009 & 47.4 & 8.50 & 3.27 & 0.001 & 1.049 & 0.210 & 4.40 & 2.07 & 2.07 \\
\hline
\end{tabular}

Horizontal lines indicate sampling periods

Blank cells indicate parameters not measured; Maximum and minimum detection limits are italicized

Maximum and minimum detection limits for major ions correspond to values listed in Table 3 
Table D2: Tabulated Meter, Alkalinity and E. coli and Total Coliform Data

\begin{tabular}{|c|c|c|c|c|c|c|c|}
\hline $\begin{array}{c}\text { LOC } \\
\text { CODE }\end{array}$ & Date & $\begin{array}{r}\text { Alk. } \\
(\mathrm{meq} / \mathrm{L})\end{array}$ & $\begin{array}{r}\text { Temp. } \\
\left({ }^{\circ} \mathrm{C}\right)\end{array}$ & pH & $\begin{array}{r}\mathrm{SC} \\
(\mathrm{mS} / \mathrm{cm})\end{array}$ & $\begin{array}{c}\text { Coliform } \\
\text { /100 mL }\end{array}$ & $\begin{array}{r}\text { E. coli } \\
/ 100 \mathrm{~mL}\end{array}$ \\
\hline ZEN & $3 / 20 / 16$ & 4.34 & 11.2 & 7.80 & 0.394 & & \\
\hline DROPL & 3/20/16 & 2.32 & 10.2 & 7.90 & 0.190 & & \\
\hline MEFF & 3/20/16 & 2.00 & 9.94 & 7.92 & 0.176 & & \\
\hline CRABT & $3 / 20 / 16$ & 2.32 & 9.83 & 7.54 & 0.218 & & \\
\hline OLDU & $3 / 21 / 16$ & 2.74 & 9.67 & 8.27 & 0.236 & & \\
\hline OLDSWT & $3 / 21 / 16$ & & 20.3 & 6.77 & 1.45 & & \\
\hline $\mathrm{ECH}$ & 3/21/16 & 1.26 & 9.39 & 8.36 & 0.148 & & \\
\hline GMILL & 3/21/16 & 1.02 & 8.89 & 8.14 & 0.106 & & \\
\hline LUGER & $3 / 21 / 16$ & 0.96 & 8.89 & 8.24 & 0.109 & & \\
\hline CBRN & 3/22/16 & 1.98 & 9.67 & 7.95 & 0.216 & & \\
\hline HANCK & 3/22/16 & 2.06 & 9.94 & 8.09 & 0.218 & & \\
\hline BROY & $3 / 22 / 16$ & 2.48 & 10.6 & 7.77 & 0.233 & & \\
\hline НATCH & 3/22/16 & 1.92 & 10.9 & 7.96 & 0.186 & & \\
\hline OLSON & $3 / 22 / 16$ & 0.80 & 9.50 & 7.64 & 0.103 & & \\
\hline QIND & $10 / 8 / 16$ & 2.65 & 16.5 & 8.10 & 0.250 & $>2419$ & 1733 \\
\hline QSEC & 10/9/16 & 2.45 & 12.6 & 8.28 & 0.255 & $>2419$ & 298.7 \\
\hline QSWT & 10/9/16 & & 13.4 & 7.33 & 0.401 & $>2419$ & 228.2 \\
\hline QRCH & $10 / 8 / 16$ & 1.87 & 17.4 & 8.20 & 0.266 & 2420 & 2420 \\
\hline
\end{tabular}




\begin{tabular}{|c|c|c|c|c|c|c|c|}
\hline $\begin{array}{l}\text { LOC } \\
\text { CODE }\end{array}$ & Date & $\begin{array}{r}\text { Alk. } \\
\text { (meq/L) }\end{array}$ & $\begin{array}{r}\text { Temp. } \\
\left({ }^{\circ} \mathrm{C}\right)\end{array}$ & pH & $\begin{array}{r}\mathrm{SC} \\
(\mathrm{mS} / \mathrm{cm})\end{array}$ & $\begin{array}{c}\text { Coliform } \\
\text { /100 mL }\end{array}$ & $\begin{array}{r}\text { E. coli } \\
/ 100 \mathrm{~mL}\end{array}$ \\
\hline QHAN & 10/8/16 & 2.44 & 17.2 & 7.72 & 0.266 & $>2419$ & 2420 \\
\hline GMILL & $12 / 2 / 16$ & 0.97 & 9.70 & 7.13 & 0.151 & 727.0 & 11.8 \\
\hline OLDSWT & $12 / 2 / 16$ & 10.7 & 21.1 & 6.34 & 2.02 & $>2419$ & 22.6 \\
\hline QSWT & $12 / 2 / 16$ & 1.79 & 9.90 & 7.02 & 0.418 & $>2419$ & 344.8 \\
\hline QSEC & $12 / 3 / 16$ & 1.19 & 6.20 & 7.43 & 0.423 & $>2419$ & 290.9 \\
\hline ZEN & $12 / 3 / 16$ & 3.98 & 11.2 & 6.86 & 0.750 & 122.3 & $<1.0$ \\
\hline QIND & 12/3/16 & 1.18 & 5.80 & 7.64 & 0.395 & $>2419$ & 167.4 \\
\hline OLSON & $12 / 3 / 16$ & 0.56 & 9.50 & 6.30 & 0.178 & $>2419$ & 25.6 \\
\hline QHAN & $12 / 4 / 16$ & 1.46 & 4.80 & 7.37 & 0.362 & $>2419$ & $>2419$ \\
\hline CRABT & $12 / 4 / 16$ & 2.55 & 11.5 & 6.61 & 0.274 & 1986 & 29.8 \\
\hline QRCH & $12 / 4 / 16$ & 1.22 & 5.50 & 7.96 & 0.327 & $>2419$ & $>2419$ \\
\hline OLDSWT & $12 / 2 / 16$ & & 21.1 & 6.34 & 2.02 & $>2419$ & 13.5 \\
\hline QRCH & $12 / 4 / 16$ & 1.27 & 5.50 & 7.96 & 0.327 & & \\
\hline GMILL & $2 / 18 / 17$ & 1.13 & 9.50 & 7.00 & 0.127 & 4.10 & $<1.0$ \\
\hline OLDSWT & 2/18/17 & 11.4 & 21.4 & 6.32 & 1.62 & 1828 & $<1.0$ \\
\hline OLDSWT & 2/18/17 & 11.4 & 21.4 & 6.32 & 1.62 & 1828 & $<1.0$ \\
\hline OLDSWT & 2/18/17 & 11.4 & 21.4 & 6.32 & 1.62 & 1259 & $<1.0$ \\
\hline QSWT & 2/18/17 & 3.79 & 9.20 & 6.78 & 0.383 & 656 & 32.0 \\
\hline OLSON & 2/18/17 & 1.13 & 9.50 & 6.85 & 0.125 & 26.5 & $<1.0$ \\
\hline QIND & 2/18/17 & 2.25 & 7.40 & 8.20 & 0.224 & 480 & 19.2 \\
\hline
\end{tabular}




\begin{tabular}{|c|c|c|c|c|c|c|c|}
\hline $\begin{array}{l}\text { LOC } \\
\text { CODE }\end{array}$ & Date & $\begin{array}{r}\text { Alk. } \\
(\mathrm{meq} / \mathrm{L})\end{array}$ & $\begin{array}{r}\text { Temp. } \\
\left({ }^{\circ} \mathrm{C}\right)\end{array}$ & pH & $\begin{array}{r}\mathrm{SC} \\
(\mathrm{mS} / \mathrm{cm})\end{array}$ & $\begin{array}{c}\text { Coliform } \\
/ 100 \mathrm{~mL}\end{array}$ & $\begin{array}{r}\text { E. coli } \\
/ 100 \mathrm{~mL}\end{array}$ \\
\hline QSEC & 2/18/17 & 2.24 & 9.20 & 8.38 & 0.226 & 545 & 67.2 \\
\hline ZEN & 2/18/17 & 4.40 & 11.1 & 7.16 & 0.417 & 10.9 & $<1.0$ \\
\hline CRABT & 2/19/17 & 2.59 & 9.40 & 6.59 & 0.250 & 436 & 1.00 \\
\hline QHAN & 2/19/17 & 2.56 & 6.60 & 7.56 & 0.280 & 872 & 68.2 \\
\hline QRCH & 2/19/17 & 2.51 & 8.40 & 7.82 & 0.273 & 521 & 85.2 \\
\hline CRABT & 3/9/17 & 2.76 & 9.80 & 6.55 & 0.269 & 124 & $<1.0$ \\
\hline DROPL & $3 / 10 / 17$ & 1.91 & 10.2 & 7.25 & 0.201 & 37.9 & 3.00 \\
\hline MEFF & 3/11/17 & 1.81 & 9.80 & 7.29 & 0.193 & 37.9 & 3.10 \\
\hline ZEN & 3/10/17 & 4.65 & 11.1 & 7.11 & 0.432 & 4.10 & $<1.0$ \\
\hline ECH & 3/10/17 & 1.43 & 9.80 & 7.03 & 0.131 & 6.30 & $<1.0$ \\
\hline GMILL & 3/10/17 & 0.99 & 9.40 & 6.75 & 0.114 & 6.30 & $<1.0$ \\
\hline LUGER & 3/10/17 & 0.85 & 9.00 & 7.19 & 0.108 & 4.10 & $<1.0$ \\
\hline OLDSWT & 3/10/17 & 11.2 & 21.3 & 6.34 & 1.63 & 1011 & 1.00 \\
\hline OLDU & 3/10/17 & 2.20 & 10.9 & 6.93 & 0.250 & 12.2 & $<1.0$ \\
\hline OLDU & 3/10/17 & 2.19 & 10.9 & 6.93 & 0.250 & 8.60 & $<1.0$ \\
\hline OLDU & 3/10/17 & 2.19 & 10.9 & 6.93 & 0.250 & 8.60 & $<1.0$ \\
\hline BROY & 3/11/17 & 2.33 & 10.0 & 6.90 & 0.170 & 30.9 & $<1.0$ \\
\hline CBRN & 3/9/17 & 1.94 & 11.0 & 6.75 & 0.166 & 67.7 & 8.50 \\
\hline HANCK & 3/9/17 & 1.96 & 10.0 & 6.92 & 0.145 & 61.3 & $<1.0$ \\
\hline НАТСН & 3/9/17 & 1.91 & 10.2 & 6.80 & 0.144 & 166 & 14.5 \\
\hline
\end{tabular}




\begin{tabular}{|c|c|c|c|c|c|c|c|}
\hline $\begin{array}{c}\text { LOC } \\
\text { CODE }\end{array}$ & Date & $\begin{array}{r}\text { Alk. } \\
(\mathrm{meq} / \mathrm{L})\end{array}$ & $\begin{array}{r}\text { Temp. } \\
\left({ }^{\circ} \mathrm{C}\right)\end{array}$ & pH & $\begin{array}{r}\mathrm{SC} \\
(\mathrm{mS} / \mathrm{cm})\end{array}$ & $\begin{array}{c}\text { Coliform } \\
/ 100 \mathrm{~mL}\end{array}$ & $\begin{array}{r}\text { E. coli } \\
/ 100 \mathrm{~mL}\end{array}$ \\
\hline OLSON & 3/11/17 & 0.86 & 8.70 & 6.68 & 0.073 & 79.8 & 1.00 \\
\hline QSWT & 3/31/17 & 2.58 & 12.0 & 7.29 & 0.218 & 1011 & 1011 \\
\hline QIND & $4 / 2 / 17$ & 1.82 & 11.0 & 7.94 & 0.142 & 914 & 397 \\
\hline QSEC & 3/31/17 & 1.83 & 11.9 & 7.47 & 0.144 & 1011 & 1011 \\
\hline QHAN & 3/31/17 & 1.03 & 12.6 & 7.18 & 0.091 & 1011 & 1011 \\
\hline QRCH & 3/31/17 & 1.80 & 12.7 & 7.03 & 0.174 & 1011 & 1011 \\
\hline QSWT & $4 / 1 / 17$ & 2.42 & 10.5 & 7.20 & 0.184 & 1011 & 501 \\
\hline QIND & $4 / 2 / 17$ & 1.83 & 11.0 & 7.94 & 0.142 & 961 & 272 \\
\hline QIND & $4 / 2 / 17$ & 1.83 & 11.0 & 7.94 & 0.142 & 961 & 272 \\
\hline QSEC & $4 / 1 / 17$ & 1.91 & 10.8 & 7.64 & 0.148 & 1011 & 1011 \\
\hline QHAN & 4/1/17 & 1.33 & 11.2 & 7.38 & 0.120 & 1011 & 961 \\
\hline QRCH & $4 / 2 / 17$ & 1.64 & 10.3 & 7.92 & 0.136 & 1011 & 756 \\
\hline GMILL & $4 / 28 / 17$ & 1.01 & 9.40 & 7.06 & 0.090 & 96.0 & 1.00 \\
\hline OLDSWT & $4 / 28 / 17$ & 9.46 & 19.9 & 6.28 & 1.21 & 1011 & 5.20 \\
\hline QSWT & 4/28/17 & 2.34 & 16.4 & 6.10 & 0.216 & 961 & 148 \\
\hline OLSON & 4/29/17 & 0.58 & 10.3 & 6.25 & 0.083 & 378 & 8.30 \\
\hline QIND & 4/29/17 & 1.94 & 19.3 & 8.25 & 0.196 & 870 & 101 \\
\hline QSEC & 4/28/17 & 1.79 & 16.4 & 7.51 & 0.166 & 914 & 129 \\
\hline ZEN & $4 / 29 / 17$ & 4.51 & 11.0 & 7.08 & 0.314 & 48.0 & $<1.0$ \\
\hline CRABT & 4/30/17 & 3.25 & 10.8 & 6.71 & 0.239 & 416 & 75.9 \\
\hline
\end{tabular}




\begin{tabular}{|c|c|c|c|c|c|c|c|}
\hline $\begin{array}{c}\text { LOC } \\
\text { CODE }\end{array}$ & Date & $\begin{array}{r}\text { Alk. } \\
\text { (meq/L) }\end{array}$ & $\begin{array}{r}\text { Temp. } \\
\left({ }^{\circ} \mathrm{C}\right)\end{array}$ & pH & $\begin{array}{r}\mathrm{SC} \\
(\mathrm{mS} / \mathrm{cm})\end{array}$ & $\begin{array}{c}\text { Coliform } \\
\text { /100 mL }\end{array}$ & $\begin{array}{r}\text { E. coli } \\
/ 100 \mathrm{~mL}\end{array}$ \\
\hline CRABT & 4/30/17 & 3.18 & 10.8 & 6.71 & 0.239 & 436 & 80.1 \\
\hline QHAN & 4/30/17 & 2.26 & 18.3 & 7.94 & 0.241 & 870 & 298.70 \\
\hline QRCH & 4/30/17 & 2.21 & 19.8 & 8.36 & 0.230 & 792 & 146 \\
\hline OLDSWT & $6 / 4 / 17$ & & 21.8 & 6.32 & 2.05 & & \\
\hline ZEN & 7/1/17 & 5.23 & 11.0 & 7.20 & 0.313 & 31.3 & $<1.0$ \\
\hline GMILL & 6/30/17 & 1.50 & 9.50 & 7.17 & 0.110 & 90.6 & $<1.0$ \\
\hline OLDSWT & 6/30/17 & 13.4 & 22.4 & 6.26 & 1.62 & 961 & 2.00 \\
\hline CRABT & $7 / 1 / 17$ & 3.95 & 13.7 & 6.80 & 0.279 & 1011 & 57.1 \\
\hline OLSON & 7/1/17 & 1.31 & 10.4 & 7.15 & 0.130 & 76.3 & $<1.0$ \\
\hline QSWT & 6/30/17 & 4.73 & 15.6 & 7.27 & 0.362 & 1921 & 87.0 \\
\hline QSEC & 6/30/17 & 2.70 & 19.3 & 8.15 & 0.234 & 2022 & 1099 \\
\hline QIND & 7/1/17 & 3.33 & 20.1 & 7.85 & 0.268 & 2022 & 356 \\
\hline QSWT & 6/30/17 & 4.77 & 15.6 & 7.27 & 0.362 & 2022 & 65.4 \\
\hline QHAN & 7/1/17 & 4.33 & 24.7 & 7.97 & 0.405 & 2022 & 1828 \\
\hline QRCH & $7 / 1 / 17$ & 3.38 & 23.7 & 8.28 & 0.316 & 2022 & 146 \\
\hline ZEN & 8/27/17 & 4.74 & 11.7 & 7.19 & 0.459 & 457 & $<1.0$ \\
\hline ZEN & 8/27/17 & 4.74 & 11.7 & 7.19 & 0.459 & 199 & $<1.0$ \\
\hline GMILL & 8/26/17 & 1.25 & 10.8 & 7.69 & 0.153 & 14.8 & $<1.0$ \\
\hline OLDSWT & 8/26/17 & 12.1 & 22.1 & 6.39 & 1.73 & 830 & $<1.0$ \\
\hline
\end{tabular}




\begin{tabular}{|c|c|c|c|c|c|c|c|}
\hline $\begin{array}{l}\text { LOC } \\
\text { CODE }\end{array}$ & Date & $\begin{array}{r}\text { Alk. } \\
\text { (meq/L) }\end{array}$ & $\begin{array}{r}\text { Temp. } \\
\left({ }^{\circ} \mathrm{C}\right)\end{array}$ & pH & $\begin{array}{r}\mathrm{SC} \\
(\mathrm{mS} / \mathrm{cm})\end{array}$ & $\begin{array}{c}\text { Coliform } \\
/ 100 \mathrm{~mL}\end{array}$ & $\begin{array}{r}\text { E. coli } \\
/ 100 \mathrm{~mL}\end{array}$ \\
\hline CRABT & 8/27/17 & 3.25 & 16.1 & 6.98 & 0.348 & 1011 & 20.1 \\
\hline WVU & 8/27/17 & 0.25 & & & & & $<1.0$ \\
\hline QSWT & 8/26/17 & 4.74 & 13.5 & 7.45 & 0.505 & 1921 & 37.4 \\
\hline QSEC & 8/26/17 & 2.74 & 16.3 & 8.31 & 0.283 & 2022 & 155 \\
\hline QIND & 8/26/17 & 5.08 & 18.8 & 8.49 & 0.294 & 2022 & 80.4 \\
\hline QHAN & 8/26/17 & 3.73 & 25.7 & 8.28 & 0.401 & 2022 & 1443 \\
\hline QRCH & 8/26/17 & 3.22 & 19.7 & 8.40 & 0.335 & 2022 & 480 \\
\hline OLDSWT & 9/11/17 & 11.9 & 21.8 & 6.44 & 1.69 & 1011 & 4.10 \\
\hline OLDU & 9/11/17 & 2.31 & 11.4 & 7.29 & 0.274 & 155 & $<1.0$ \\
\hline QSWT & 9/11/17 & & 13.5 & 7.29 & 0.508 & & \\
\hline $\mathrm{ECH}$ & 9/11/17 & 1.53 & 9.80 & 7.46 & 0.178 & 3.10 & $<1.0$ \\
\hline GMILL & 9/11/17 & 1.31 & 9.50 & 7.37 & 0.165 & 42.6 & 1.00 \\
\hline LUGER & 9/11/17 & 1.17 & 8.90 & 7.58 & 0.150 & 11.0 & $<1.0$ \\
\hline QRCH & 9/12/17 & & 14.6 & 7.89 & 0.366 & & \\
\hline CBRN & 9/12/17 & 3.20 & 11.4 & 6.95 & 0.334 & 272 & 5.20 \\
\hline HANCK & 9/12/17 & 2.17 & 10.6 & 6.89 & 0.271 & 107 & 1.00 \\
\hline ZEN & 9/12/17 & 4.70 & 11.0 & 7.16 & 0.462 & 914 & 1.00 \\
\hline DROPL & 9/12/17 & 2.75 & 10.9 & 7.32 & 0.288 & 219 & 3.10 \\
\hline MEFF & 9/12/17 & 2.72 & 10.8 & 7.24 & 0.285 & 210 & 2.00 \\
\hline
\end{tabular}




\begin{tabular}{|c|c|c|c|c|c|c|c|}
\hline $\begin{array}{l}\text { LOC } \\
\text { CODE }\end{array}$ & Date & $\begin{array}{r}\text { Alk. } \\
(\mathrm{meq} / \mathbf{L})\end{array}$ & $\begin{array}{l}\text { Temp. } \\
\left({ }^{\circ} \mathbf{C}\right)\end{array}$ & pH & $\begin{array}{r}\mathrm{SC} \\
(\mathrm{mS} / \mathrm{cm})\end{array}$ & $\begin{array}{c}\text { Coliform } \\
/ 100 \mathrm{~mL}\end{array}$ & $\begin{array}{r}\text { E. coli } \\
/ 100 \mathrm{~mL}\end{array}$ \\
\hline BROY & 9/12/17 & 2.66 & 11.2 & 7.07 & 0.308 & 160 & $<1.0$ \\
\hline НATCH & 9/12/17 & 2.83 & 11.3 & 7.00 & 0.300 & 1011 & 19.9 \\
\hline OLSON & $9 / 12 / 17$ & 1.40 & 10.3 & 7.24 & 0.183 & 344 & $<1.0$ \\
\hline OLSON & 9/12/17 & 1.40 & 10.3 & 7.24 & 0.183 & 575 & $<1.0$ \\
\hline WVU & 9/12/17 & 0.03 & & & & $<1.0$ & $<1.0$ \\
\hline QIND & 9/13/17 & & 16.0 & 7.63 & 0.321 & & \\
\hline QHAN & 9/13/17 & & 16.1 & 7.52 & 0.430 & & \\
\hline OLSON & 12/17/17 & 1.36 & 9.90 & 6.74 & 0.180 & 43.2 & $<1.0$ \\
\hline QHAN & 12/17/17 & 3.51 & 1.00 & 7.75 & 0.399 & 1011 & 24.6 \\
\hline ZEN & 12/17/17 & 4.70 & 10.9 & 6.99 & 0.449 & 36.9 & 2.00 \\
\hline ZEN & 12/17/17 & 4.69 & 10.9 & 6.99 & 0.449 & 37.9 & $<1.0$ \\
\hline GMILL & 12/18/17 & 1.26 & 9.50 & 7.20 & 0.146 & 6.30 & $<1.0$ \\
\hline OLDSWT & 12/18/17 & 11.9 & 21.1 & 6.44 & 1.56 & 1011 & $<1.0$ \\
\hline QSWT & 12/18/17 & 4.74 & 12.0 & 7.15 & 0.439 & & \\
\hline QSEC & 12/18/17 & 2.51 & 8.10 & 7.90 & 0.247 & & \\
\hline QIND & $12 / 19 / 17$ & 2.73 & 4.30 & 8.00 & 0.279 & & \\
\hline CRABT & 12/19/17 & 3.80 & 8.50 & 6.75 & 0.399 & 914 & 1.00 \\
\hline QRCH & 12/19/17 & 2.88 & 6.10 & 8.34 & 0.302 & & \\
\hline
\end{tabular}


Horizontal lines indicate sampling periods

Blank cells indicate parameters not measured; Maximum and minimum detection limits

are italicized

Maximum detection limit for IDEXX results are 2419.6, minimum detection limits for

IDEXX results are 1.0

Alk.=Alkalinity; Temp.=Temperature; SC= Specific Conductance 